\title{
Critical review evaluating the pig as a model for human nutritional physiology
}

\author{
Eugeni Roura $^{1 *}$, Sietse-Jan Koopmans ${ }^{2}$, Jean-Paul Lallès ${ }^{3}$, Isabelle Le Huerou-Luron ${ }^{3}$, Nadia de Jager ${ }^{1}$, \\ Teun Schuurman ${ }^{2}$ and David Val-Laillet ${ }^{3}$ \\ ${ }^{1}$ The University of Queensland, Centre for Nutrition and Food Sciences, Queensland Alliance for Agriculture and Food \\ Innovation, St. Lucia, QLD 4072, Australia \\ ${ }^{2}$ Wageningen University and Research Centre, Animal Sciences Group, 6708 WD Wageningen, The Netherlands \\ ${ }^{3}$ INRA, UR1341 ADNC, 35590 St Gilles, France
}

\section{Abstract}

The present review examines the pig as a model for physiological studies in human subjects related to nutrient sensing, appetite regulation, gut barrier function, intestinal microbiota and nutritional neuroscience. The nutrient-sensing mechanisms regarding acids (sour), carbohydrates (sweet), glutamic acid (umami) and fatty acids are conserved between humans and pigs. In contrast, pigs show limited perception of high-intensity sweeteners and $\mathrm{NaCl}$ and sense a wider array of amino acids than humans. Differences on bitter taste may reflect the adaptation to ecosystems. In relation to appetite regulation, plasma concentrations of cholecystokinin and glucagon-like peptide- 1 are similar in pigs and humans, while peptide YY in pigs is ten to twenty times higher and ghrelin two to five times lower than in humans. Pigs are an excellent model for human studies for vagal nerve function related to the hormonal regulation of food intake. Similarly, the study of gut barrier functions reveals conserved defence mechanisms between the two species particularly in functional permeability. However, human data are scant for some of the defence systems and nutritional programming. The pig model has been valuable for studying the changes in human microbiota following nutritional interventions. In particular, the use of human flora-associated pigs is a useful model for infants, but the long-term stability of the implanted human microbiota in pigs remains to be investigated. The similarity of the pig and human brain anatomy and development is paradigmatic. Brain explorations and therapies described in pig, when compared with available human data, highlight their value in nutritional neuroscience, particularly regarding functional neuroimaging techniques.

\section{Key words: Pig model: Nutrition: Chemosensing: Food intake: Microbiota}

\section{Introduction}

Rodents, mainly mice, have become the model for studies related to human physiology and genetics. However, the differences between rodents and humans in dietary habits, digestive strategies including coprophagy, nutrient requirements and nutrientnutrient interactions suggest the pig may be a closer match than rodents for studying physiological functions relating to these research areas ${ }^{(1-4)}$. The suitability of the pig as a model for human research is becoming accepted, particularly related to physiological factors and biomedical applications ${ }^{(2,5-7)}$. Both humans and pigs are classified as omnivorous mammals and share similarities related to anatomical features of the gastrointestinal tract (GIT), such as the size of the compartments and the predominance of the colon rather than the caecum as the main fermentation site of plant/fibrous dietary components ${ }^{(2,8)}$. Pigs have been used to study several areas relevant to human nutritional sciences ${ }^{(1,2,9-11)}$, including metabolic syndromes, obesity, bariatric surgery ${ }^{(2,5)}$, neuroscience, brain imaging ${ }^{(3,12)}$, food allergies $^{(13)}$, alcohol intake $\mathrm{e}^{(14,15)}$ and mother-offspring interactions ${ }^{(16)}$. In addition, the sequencing of the pig genome has widened support for using the pig as a model for humans by revealing the similarities and differences between pigs and humans at the gene and chromosomal levels ${ }^{(17)}$.

The present review provides a critical evaluation of the pig as a model for studies related to humans in areas that encompass nutritional chemosensing and hormonal profiles relevant to feed/ food intake, the gut barrier function, the host-microbiota interactions and the relationship between nutrition and brain development and metabolism. In addition, the present paper assesses, as quantitatively as possible, how appropriate it would be to use the pig as a model for humans for each of the areas discussed.

\section{Nutritional chemosensing}

The chemosensory system has evolved to allow animals to discriminate between foods in their environment, and is believed to

Abbreviations: AA, amino acid; BBB, blood-brain barrier; CCK, cholecystokinin; DBS, deep-brain stimulation; DVZ, devazepide; FA, fatty acid; GIT, gastrointestinal tract; GLP-1, glucagon-like peptide-1; GLU, glucose; HSP, heat shock protein; IAP, intestinal alkaline phosphatase; icv, intracerebroventricular; iv, intravenous; LPS, lipopolysaccharide; MAMP, microbial-associated molecular pattern; PYY, peptide YY; SUC, sucrose; TAS1R, taste receptor type 1; TAS2R, taste receptor type 2; T1R, taste 1 receptor; TR, taste receptor; VNS, vagal nerve stimulation.

* Corresponding author: Eugeni Roura, email e.roura@uq.edu.au 
reflect species-specific dietary needs ${ }^{(18)}$. For example, humans have developed trichromatic vision, which was a key event relevant to food recognition and may have contributed to decrease the reliance on olfaction ${ }^{(19)}$. In contrast, pigs appear to have the largest olfactory gene repertoire of any animal studied, with 1,301 potential olfactory receptor genes ${ }^{(20)}$. The potential for pigs to become a model for human research in olfaction is relevant in the case of maternal transfer of dietary cues ${ }^{(21-24)}$.

Nutritional chemosensing is the science studying the perception of nutrients in biological systems which relates molecular mechanisms to changes in genomic, metabolic, physiological and behavioural parameters. Dietary nutrients are perceived in the oral cavity through the taste system in both pigs and humans ${ }^{(25,26)}$.

\section{Taste perception and the nutrient chemosensory system}

Five basic tastes are accepted in humans: sweet, umami, salty, sour and bitter. In addition, fat perception and other nutrient sensing have been related to taste ${ }^{(25)}$. Sapid compounds solubilised in saliva are presented to the taste buds in the tongue papillae ${ }^{(27)}$. Taste perception involves a large set of taste receptors (referred hereinafter as TR for the receptors and TASR for the corresponding genes), which are expressed in the sensory cells of the taste buds and account for recognition of the tastants triggering a depolarisation of the cell and the subsequent signalling to the gustatory cortex of the brain through dedicated neuronal fibres ${ }^{(28)}$. Salty and sour sensing has been related to ligand-gated, transmembrane-channels: the epithelial $\mathrm{Na}$ channels (involving three genes $E N a C \alpha, \beta, \gamma$ ) and the hydrogen-gated channels (involving two genes PKD1L3 and PKD2L1), respectively ${ }^{(25)}$. All other taste and nutrient receptors known to date are G-protein-coupled receptors (GPCR), including the family 1 (T1R), family 2 (T2R) and several other receptors related to amino acid (AA) and fatty acid (FA) sensing. In humans, the three genes of the taste receptor type 1 (TAS1R) subfamily have been related to umami and sweet tastes. They sense a limited range of L-AA (TAS1R1 and TAS1R3) and sugars (TAS1R2 and TAS1R3). The taste receptor type 2 (TAS2R) subfamily has evolved to identify potentially toxic compounds and elicits the bitter taste. In addition to the Tas1R family, AA and peptones are sensed in the oral cavity by five other GPCR receptors (mGluR1, mGluR4, GPRC6A, CaSR and GPR92). Medium- and long-chained FA are sensed by another set of five GPCR (GPR40, GPR41, GPR43, GPR84 and GPR120). Detailed reviews of the TR/TASR, including the standard nomenclature, are given for humans and rodents by Bachmanov \& Beauchamp ${ }^{(25)}$, Wellendorph et al. ${ }^{(26)}$ and Foster et al. ${ }^{(29,30)}$.

The pig nutrient-sensing repertoire is less known but several in silico comparisons of taste receptors have been published in the last 3 years, after the appearance of the second annotation of the pig genome ${ }^{(18,20,31-33)}$. Single gene sequencing in pigs has characterised the porcine TAS1R3 ${ }^{(34)}$. The gene sequences for the porcine umami dimer, TAS1R1/TAS1R3, and the glutamate receptor, mGluR1, have also been published ${ }^{(4,35)}$. More recently a study including allelic variation and oral expression of the porcine TAS2R family indicated the potential role of the bitter receptors in environmental adaptation ${ }^{(31)}$.
Evidence for expression of TR in the GIT outside the oral cavity has emerged from both pig and human genome studies $^{(26,30)}$. For example, expression of the Tas1r3 gene has been identified in the tongue, heart, lung, stomach, intestine, liver, kidney and testis ${ }^{(34)}$. Other nutrient receptors have been found along the GIT including T1R in the small intestine and stomach $^{(36-38)}$; AA and peptone receptors, GPRC6A, GPR92 and CaSR, in gastric mucosa ${ }^{(39)}$; and FA sensors, GPR 40, 43 and 120, and seven TAS2R, in five different tissues of the $\mathrm{GIT}^{(40)}$.

\section{Comparisons between pigs and humans in nutritional chemosensing}

Pigs have a high number of taste buds ( $n$ 19 904) relative to other animal species. The number recorded for humans ( $n$ 6074) is about $30 \%$ that for pigs. Most of these taste buds are on the tongue surface as part of the fungiform papillae or on the circumvallate papillae in pigs and humans ${ }^{(41,42)}$. Pigs have a larger number of fungiform papillae than humans and only two circumvallate papillae compared with eight to twelve in humans ${ }^{(43)}$. However, the ratio of taste buds to adult body weight is similar for pigs and humans, as it is across many animal species ${ }^{(44)}$.

Sensitivity of pigs compared with humans for the basic hedonic human tastes (sweet, umami, salty, sour and bitter) and homology between taste gene sequences are shown in Tables 1 and 2, respectively. Molecular mechanisms and taste sensitivity are generally similar between the two species for sweet, umami, sour and FA tastes. However, similarities are less for salty and low for bitter tastes.

In relation to sweet tastes, the first studies in pigs from the 1950 s were on appetite for sucrose (SUC) ${ }^{(45,46)}$. Kennedy \& Baldwin $^{(47)}$ also measured preferences by pigs for several sweet compounds and found similar recognition threshold concentrations in the diet for SUC and sodium saccharin (SAC) of about 5 to $10 \mathrm{~mm}$. The taste recognition threshold was higher for glucose (GLU) at between 10 and $30 \mathrm{~mm}$. Humans show a similar sensitivity to pigs for simple sugars and for two high-intensity sweeteners, sucralose and rebaudioside $\mathrm{A}^{(48,49)}$. However, pigs do not respond to aspartame, neohesperidin and thaumatin ${ }^{(48,49)}$, which are recognised as sweet by humans. SAC solutions above $100 \mathrm{~mm}$ were rejected by pigs ${ }^{(45)}$, suggesting an unpleasant sensation at high concentrations. This response is similar for humans, where high SAC concentrations elicit bitterness ${ }^{(50)}$.

Pigs have a preference for free L-AA including glutamic, aspartic, alanine, glutamine and lysine which have been related to the porcine umami taste receptor ${ }^{(4)}$. In addition, preferences for serine, threonine, asparagine and hydroxyproline have also been reported in pigs ${ }^{(51)}$. However, pig preferences for AA or sugars seem to increase with dietary deficiencies ${ }^{(52,53)}$. In contrast to the AA listed above, pigs have been shown to avoid branched-chained AA and tryptophan, presumably related to the onset of bitter taste ${ }^{(51,54,55)}$. Compounds known to be bitter to humans such as pharmaceuticals, including antibiotics, caffeine, quinine $\mathrm{HCl}$, among others, have also been shown to trigger avoidance in pigs ${ }^{(56,57)}$.

Humans appear to be less sensitive to umami tastants than pigs. Umami taste in humans is stimulated by only two L-AA 


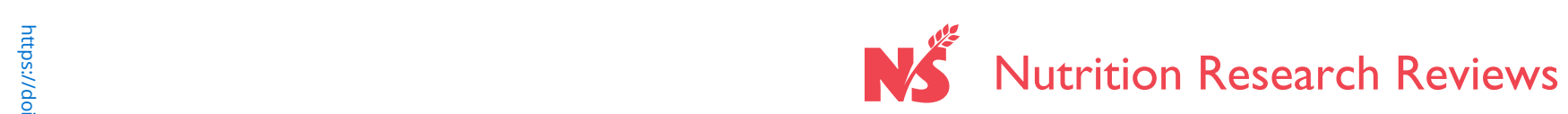

Table 1. Efficacy of the pig model for humans in nutritional chemosensing; endocrine system; microbiota; and brain anatomy, development and imaging

\begin{tabular}{|c|c|c|c|c|c|}
\hline Topic & Parameter & Pigs & Humans & Relevance of the pig as a human model & References \\
\hline \multicolumn{6}{|l|}{ Nutritional chemosensing } \\
\hline \multirow[t]{3}{*}{ Anatomy } & Taste bud number & 19904 & 6974 & Low & Chamorro et al. ${ }^{(41)}$; Miller \& Reedy ${ }^{(43)}$ \\
\hline & $\begin{array}{l}\text { Taste bud number:body weight } \\
\text { ratio* }\end{array}$ & $103 \cdot 7$ & $102 \cdot 6$ & High & Chamorro et al. ${ }^{(41)}$; Miller \& Reedy ${ }^{(43)}$ \\
\hline & Circumvallate papillae number & 2 & $8-12$ & Low & Kumar \& Bate ${ }^{(313)} ;$ Miller \& Reedy ${ }^{(43)}$ \\
\hline \multirow[t]{4}{*}{$\begin{array}{l}\text { Molecular } \\
\text { mechanisms }\end{array}$} & Carbohydrate sensing & TAS1R2 and TAS1R3 & $\begin{array}{l}\text { TAS1R2 and } \\
\text { TAS1R3 }\end{array}$ & $\begin{array}{l}\text { High. Same genes. High gene homology } \\
\text { ranging from } 75 \text { to } 76 \% \text { in nucleotide } \\
\text { sequence. Low SNP incidence }\end{array}$ & $\begin{array}{l}\text { Roura }{ }^{(62)} \text {; Da Silva et al. }{ }^{(31)} \text {; Bachmanov \& } \\
\quad \text { Beauchamp }\end{array}$ \\
\hline & Amino acid sensing & $\begin{array}{l}\text { GPRC6A, mGluR1 and 4, } \\
\text { CaSR and GPR92 }\end{array}$ & $\begin{array}{l}\text { GPRC6A, mGluR1 } \\
\text { and 4, CaSR } \\
\text { and GPR92 }\end{array}$ & $\begin{array}{l}\text { Very high. Same genes. Very high gene } \\
\text { homology ranging from } 77 \text { to } 99 \% \text { in } \\
\text { nucleotide sequence. Low SNP incidence }\end{array}$ & $\begin{array}{l}\text { Roura }{ }^{(62)} ; \text { Da Silva et al. }{ }^{(31)} \text {; Wellendorph } \\
\quad \text { et al. }{ }^{(314)}\end{array}$ \\
\hline & Fatty acid sensing & GPR $40,41,43,84$ and 120 & $\begin{array}{l}\text { GPR } 40,41,43,84 \\
\quad \text { and } 120\end{array}$ & $\begin{array}{l}\text { High. Same genes. High gene homology } \\
\text { ranging from } 75 \text { to } 90 \% \text { in nucleotide } \\
\text { sequence. Low SNP frequency }\end{array}$ & $\begin{array}{l}\text { Roura }{ }^{(62)} \text {; Da Silva et al. }{ }^{(31)} \text {; Wellendorph } \\
\quad \text { et al. }{ }^{(314)}\end{array}$ \\
\hline & Bitter taste & $\begin{array}{l}12 \text { functional genes and } \\
3 \text { pseudogenes }\end{array}$ & 25 functional genes & $\begin{array}{l}\text { Very low. Different genes. Eleven human genes } \\
\text { without pig ortholog. Two pig genes without } \\
\text { human ortholog. Medium to very low gene } \\
\text { homology ranging from } 54 \text { to } 73 \% \text { in } \\
\text { nucleotide sequence. High SNP frequency }\end{array}$ & Da Silva et al. ${ }^{(31)}$; Kuhn et al. ${ }^{(315)}$ \\
\hline \multirow[t]{5}{*}{$\begin{array}{l}\text { Taste sensitivity } \\
\text { threshold }\end{array}$} & Sweet, sucrose $(\mathrm{mm}) \dagger$ & 6 & 8.8 & $\begin{array}{l}\text { Very high for simple sugars. } \\
\text { Low or very low for artificial sweeteners }\end{array}$ & Roura et al..$^{(4)}$; Newman \& Keast ${ }^{(331)}$ \\
\hline & Umami, MSG (mм)† & 3 & 1.6 & $\begin{array}{l}\text { High for glutamate. Very low for other L-amino } \\
\text { acids }\end{array}$ & Roura et al. ${ }^{(4)} ;$ Newman \& Keast ${ }^{(331)}$ \\
\hline & Sour, citric acid $(\mathrm{mm}) \dagger$ & 0.4 & 0.8 & $\begin{array}{l}\text { High for citric acid. Medium or low for other acids } \\
\text { since pigs show preference for several organic } \\
\text { and inorganic acids (unpublished results) }\end{array}$ & Roura et al. ${ }^{(4)} ;$ Newman \& Keast ${ }^{(331)}$ \\
\hline & Salty, $\mathrm{NaCl}(\mathrm{mм}) \dagger$ & 18 & $4 \cdot 2$ & Medium & Roura et al. ${ }^{(4)} ;$ Newman \& Keast ${ }^{(331)}$ \\
\hline & Bitter $(\mathrm{mm}) \dagger$ & Unknown & $\begin{array}{l}\text { Diverse, but often } \\
\text { ranging in the } \mu \mathrm{M} \\
\text { range }\end{array}$ & Unknown & Brochoff et al. ${ }^{(316)}$ \\
\hline \multicolumn{6}{|c|}{ Endocrine system (blood hormone levels; pmol/l) } \\
\hline \multirow[t]{4}{*}{$\begin{array}{l}\text { Postprandial } \\
\text { response }\end{array}$} & $\mathrm{CCK}$ & 2- to 5 -fold & 2- to 5 -fold & $\begin{array}{l}\text { Very high. Quantitative and qualitative changes } \\
\text { are similar }\end{array}$ & $\begin{array}{l}\text { Corring \& Chayvialle }{ }^{(71)} \text {; Clutter et al. } .^{(72)} \text {; } \\
\text { Ripken et all }{ }^{(73)} \text {; Feinle et al. }{ }^{(76)} \text {; Seimon } \\
\text { et al. }{ }^{(77)} \text {; Blom et al. }{ }^{(78)} \text {; Mossner et al. } .^{(79)}\end{array}$ \\
\hline & GLP-1 & About 3-fold & About 3-fold & $\begin{array}{l}\text { Very high. Quantitative and qualitative changes } \\
\text { are similar }\end{array}$ & $\begin{array}{l}\text { Souza da Silva et al. }{ }^{(95)} \text {; Hooda et al. }{ }^{(96)} \text {; } \\
\text { Knapper et al. }{ }^{(97)} \text {; Blom et al. }{ }^{(78)} \text {; Lavin } \\
\text { et al. }{ }^{(98)} \text {; Verdich et al. } .^{(99)}\end{array}$ \\
\hline & PYY & 1- to 2 -fold & About 4-fold & $\begin{array}{l}\text { Low. Levels are different and changes in } \\
\text { response to nutritional status as well }\end{array}$ & $\begin{array}{l}\text { Souza da Silva et al. }{ }^{(95)} \text {; Ito et al } .^{(107)} \\
\text { Seimon et al. } \\
{ }^{(77)} \text {; Degen et al. }{ }^{(106)}\end{array}$ \\
\hline & Ghrelin & 2- to 3-fold & 2- to 3-fold & $\begin{array}{l}\text { Medium. Changes are similar but plasma levels } \\
\text { differ significantly }\end{array}$ & $\begin{array}{l}\text { Barretero-Hernandez et al. } l^{(65)} \text {; Govoni } \\
\text { et al. }{ }^{\left({ }^{(108)} ;\right.} \text { Zhang et al. }{ }^{(110)} \text {; Inoue et al. }{ }^{(111)} \text {; } \\
\text { Scrimgeour et al. } .^{(1112)} \text {; Blom et al. } .^{(78)} \text {; } \\
\text { Cummings et al. }{ }^{(113)} \\
\text { Pigs } s^{(65,108,110-112)} \\
\text { Humans }{ }^{(78,113)}\end{array}$ \\
\hline Effect on food intake & $\mathrm{CCK}$ & Reduction & Reduction & Very high ${ }^{(89,90)}$. Same effect on appetite & 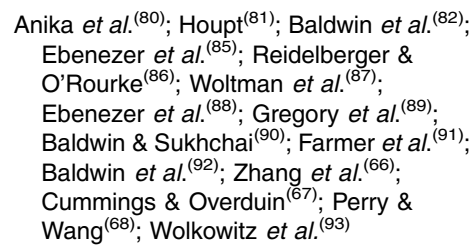 \\
\hline
\end{tabular}




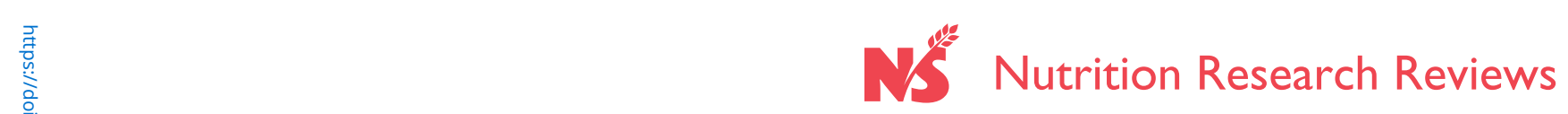

Table 1 Continued

\begin{tabular}{|c|c|c|c|c|c|}
\hline Topic & Parameter & Pigs & Humans & Relevance of the pig as a human model & References \\
\hline & GLP-1 & $\begin{array}{l}\text { Circumstantial evidence for } \\
\text { reduction }\end{array}$ & Reduction & Very high. Same effect on appetite & $\begin{array}{l}\text { Ribel et al. }{ }^{(101)} \text {; Knudsen }{ }^{(103)} \text {; Zhang } \\
\text { et al. } \text { (66); }^{\text {Cummings \& Overduin }}{ }^{(67)} \text {; } \\
\text { Perry \& Wang }{ }^{(68)}\end{array}$ \\
\hline & PYY & Reduction & Reduction & Very high. Same effect on appetite & $\begin{array}{l}\text { Ito et al. }{ }^{(107)} \text {; Zhang et al. }{ }^{(66)} \text {; Cummings \& } \\
\text { Overduin (67); Perry \& Wang }{ }^{(68)} \text {; Degen } \\
\text { et al. }{ }^{(106)}\end{array}$ \\
\hline & Ghrelin & Increment & Increment & Very high. Same effect on appetite & $\begin{array}{l}\text { Salfen et al. }{ }^{(114)} \text {; Zhang et al. } \\
\text { Cumming); } \\
\text { Wang }{ }^{(68)} ; \text { [e Roux et al. }{ }^{(115)}\end{array}$ \\
\hline \multicolumn{6}{|l|}{ Microbiota } \\
\hline \multirow{11}{*}{$\begin{array}{l}\text { Bacterial } \\
\text { enterotypes }\end{array}$} & Number of major enterotypes & Two & Three & Medium & Arumugam et al. ${ }^{(173)}$; Mach et al. ${ }^{(175)}$ \\
\hline & Enterotype-like clusters & $\begin{array}{l}\text { Prevotella } \\
\text { Ruminococcus }\end{array}$ & $\begin{array}{l}\text { Prevotella } \\
\text { Ruminococcus } \\
\text { Bacteroides }\end{array}$ & Medium & Arumugam et al. ${ }^{(173)}$; Mach et al..$^{(175)}$ \\
\hline & $\begin{array}{l}\text { Over time variation of } \\
\text { enterotype clusters }\end{array}$ & Yes & Yes & High & Arumugam et al. ${ }^{(173)}$; Mach et al. ${ }^{(175)}$ \\
\hline & Dominant phyla & Firmicutes Bacteroidetes & $\begin{array}{l}\text { Firmicutes } \\
\text { Bacteroidetes }\end{array}$ & High & $\begin{array}{l}\text { Eckburg et al. } .^{(182)} \text {; Ley et al }{ }^{(183)} \text {; Leser } \\
\text { et al. }{ }^{(185)} \text {; Guo et al. }{ }^{(186)} \text {; Mach et al. }{ }^{(175)}\end{array}$ \\
\hline & $\begin{array}{l}\text { Dominant genera of } \\
\text { Bacteroidetes }\end{array}$ & Prevotella & Bacteroides & Low & Dore \& Corthier ${ }^{(199)} ;$ Kim et al..$^{(211)}$ \\
\hline & $\begin{array}{l}\text { Relative abundance of } \\
\text { bifidobacteria (in } \\
\text { Actinobacteria phyla) }\end{array}$ & $\begin{array}{l}\text { Very low amount in } 5 \text {-month- } \\
\text { old pigs }(<0.01 \% \text { of total } \\
\text { sequences })\end{array}$ & $\begin{array}{l}\text { Predominant in } \\
\text { infants ( } 40 \% \text { of } \\
\text { total bacteria) }\end{array}$ & Low & $\begin{array}{l}\text { Adlerberth \& Wold }{ }^{(317)} \text {; Dore \& } \\
\text { Corthier(199); Kim et al. }{ }^{(211)} ; \text { Mach } \\
\text { et al. }{ }^{(175)}\end{array}$ \\
\hline & Early colonisers of the intestine & $\begin{array}{l}\text { Bacteroides } \\
\text { Escherichia/Shigella } \\
\text { Lactobacillus }\end{array}$ & $\begin{array}{l}\text { Bacteroides } \\
\text { Escherichial } \\
\text { Shigella }\end{array}$ & Medium & Fallani et al. ${ }^{(212)}$; Wang et al..$^{(318)}$ \\
\hline & & Streptococcus & Bifidobacteria & & \\
\hline & $\begin{array}{l}\text { Environmental factors that } \\
\text { modify early microbial } \\
\text { colonisation }\end{array}$ & $\begin{array}{l}\text { Mode of delivery } \\
\text { Nutrition } \\
\text { Antibiotic treatment }\end{array}$ & $\begin{array}{l}\text { Mode of delivery } \\
\text { Nutrition } \\
\text { Antibiotic treatment }\end{array}$ & High & $\begin{array}{l}\text { Adlerberth \& Wold }{ }^{(317)} \text {; Donovan et al. } .^{(177)} \text {; } \\
\text { Fallani et al. }{ }^{(212)} \text {; Le Huërou-Luron } \\
\text { et al. }{ }^{(206)} \text { : Mulder et al. }{ }^{(202)} \text {; Pinsk }\end{array}$ \\
\hline & & $\begin{array}{l}\text { Biodiversity in the surrounding } \\
\text { environment and in family } \\
\text { members }\end{array}$ & $\begin{array}{l}\text { Biodiversity in the } \\
\text { surrounding } \\
\text { environment and } \\
\text { in family } \\
\text { members }\end{array}$ & & et al. ${ }^{(204)}$; Wang et al. ${ }^{(318)}$ \\
\hline & $\begin{array}{l}\text { Evidence for long-term } \\
\text { consequences of early } \\
\text { modification of microbiota }\end{array}$ & Yes & Yes & High & $\begin{array}{l}\text { Arnal et al. } .^{(137)} \text {; Boudry et al. }{ }^{(158)} \text {; Chatelais } \\
\quad \text { et }{ }^{\left({ }^{(157)}\right.} \text {; Le Huërou-Luron et al. }\end{array}$ \\
\hline \multirow{2}{*}{$\begin{array}{l}\text { Firmicutes and } \\
\text { Bacteroidetes } \\
\text { abundance }\end{array}$} & In lean adults & $\begin{array}{l}\text { Firmicutes } 68-79 \% \\
\text { Bacteroidetes } 12-16 \%\end{array}$ & $\begin{array}{l}\text { Firmicutes } 74 \% \\
\text { Bacteroidetes } 26 \%\end{array}$ & High & Ley et al. ${ }^{(184)}$; Guo et al. ${ }^{(186)}$; Kim et al. ${ }^{(211)}$ \\
\hline & In obese adults & $\begin{array}{l}\text { Firmicutes } 71 \% \\
\text { Bacteroidetes } 5 \%\end{array}$ & $\begin{array}{l}\text { Firmicutes } 89 \% \\
\text { Bacteroidetes } 2 \%\end{array}$ & High & Ley et al. ${ }^{(184)}$; Guo et al. ${ }^{(186)}$ \\
\hline \multicolumn{6}{|c|}{ Brain anatomy, development and imaging } \\
\hline Brain anatomy & Brain weight & $180 \mathrm{~g}$ & $1.3-1.4 \mathrm{~kg}$ & $\begin{array}{l}\text { Fairly good. Pig brain comparable with the } \\
\text { brain mass of several non-human primate } \\
\text { species, which enables a good resolution for } \\
\text { brain imaging }\end{array}$ & Sauleau et al. ${ }^{(12)}$ \\
\hline
\end{tabular}




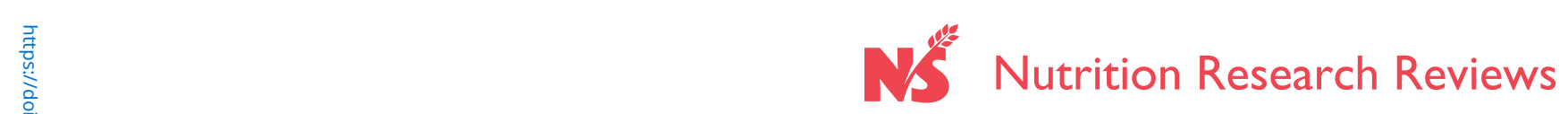

Table 1 Continued

\begin{tabular}{|c|c|c|c|c|c|}
\hline Topic & Parameter & Pigs & Humans & Relevance of the pig as a human model & References \\
\hline & Brain shape (isomorphic factor) & 50 & 65 & $\begin{array}{l}\text { Good. In comparison, the isomorphy factor of } \\
\text { the rat brain is } 10\end{array}$ & Lind et al. ${ }^{(319)}$; Sauleau et al..$^{(12)}$ \\
\hline & $\begin{array}{l}\text { Total number of neocortical } \\
\text { neurons }\end{array}$ & 325-430 million & 19-23 billion & $\begin{array}{l}\text { Fairly good. In comparison, the total number of } \\
\text { neocortical neurons is } 21 \text { million in the rat, } \\
\text { and } 1.35 \text { billion in the rhesus monkey }\end{array}$ & $\begin{array}{l}\text { Pakkenberg \& Gundersen }{ }^{(320)} \text {; } \\
\text { Jelsing et al. }{ }^{\left({ }^{321)} ;\right.} \text { Christensen et al. }{ }^{(322)}\end{array}$ \\
\hline & $\begin{array}{l}\text { General anatomy and } \\
\text { vascularisation }\end{array}$ & & & $\begin{array}{l}\text { Good. Pig brain similar to that of humans in } \\
\text { terms of anatomy and vascularisation }\end{array}$ & Vodicka et al. ${ }^{(323)}$; Lind et al. ${ }^{(319)}$ \\
\hline & $\begin{array}{l}\text { Presence of cortical } \\
\text { circumvolutions }\end{array}$ & Yes & Yes & $\begin{array}{l}\text { Good. Contrary to the rat brain, the pig brain is } \\
\text { gyrencephalic such as the human brain }\end{array}$ & Sauleau et al. ${ }^{(12)}$ \\
\hline & $\begin{array}{l}\text { Description of brain } \\
\text { neurotransmitters involved in } \\
\text { eating behaviour }\end{array}$ & $\begin{array}{l}\text { Serotonin, dopamine, opioids, } \\
\text { etc. }\end{array}$ & $\begin{array}{l}\text { Serotonin, } \\
\text { dopamine, } \\
\text { opioids, etc. }\end{array}$ & Good & Niblock et al..$^{(324)}$; Lind et al. ${ }^{(319)}$ \\
\hline \multirow[t]{2}{*}{ Brain development } & Brain growth spurt & $\begin{array}{l}\text { From late prenatal to early } \\
\text { postnatal }\end{array}$ & $\begin{array}{l}\text { From late prenatal } \\
\text { to early } \\
\text { postnatal }\end{array}$ & Very good & Lind et al. ${ }^{(319)}$; Conrad et al. ${ }^{(325)}$ \\
\hline & $\begin{array}{l}\text { Maturation of postnatal brain } \\
\text { (\% of adult brain volume) }\end{array}$ & $50 \%$ at $3.81-4.08$ weeks & $36 \%$ at $2-4$ weeks & $\begin{array}{l}\text { Good. The large increase in brain volume in the } \\
\text { postnatal period is similar to human } \\
\text { neonates and indicates that pigs can be } \\
\text { used to investigate brain development }\end{array}$ & Conrad et al. ${ }^{(325)}$ \\
\hline \multirow[t]{3}{*}{ Brain imaging } & $\begin{array}{l}\text { Validated brain imaging } \\
\text { techniques }\end{array}$ & $\begin{array}{l}\text { CT, PET, SPECT, MRI, MEG, } \\
\text { ECoG, NIRS }\end{array}$ & $\begin{array}{l}\text { CT, PET, SPECT, } \\
\text { MRI, MEG, } \\
\text { ECoG, NIRS }\end{array}$ & $\begin{array}{l}\text { Very good. All major brain imaging techniques } \\
\text { in the human have been implemented in the } \\
\text { pig model }\end{array}$ & $\begin{array}{l}\text { Bowyer et al. }{ }^{(283)} \text {; Lind et al. }{ }^{(319)} \text {; } \\
\text { Sauleau et al. } .^{(12)} \text {; Clouard et al. }{ }^{(3)} \text {; } \\
\text { Uga et al. }{ }^{(284)}\end{array}$ \\
\hline & $\begin{array}{l}\text { Validated brain PET } \\
\text { radioligands }\end{array}$ & 39 & $\begin{array}{l}178 \text { (specifically for } \\
\text { brain imaging } \\
\text { over } 569 \text { PET } \\
\text { radioligands in } \\
\text { the MICAD } \\
\text { database) }\end{array}$ & $\begin{array}{l}\text { Good. PET radioligands were validated in pigs } \\
\text { to study the cerebral blood flow, the } \\
\text { metabolism of glucose, dopamine, } \\
\text { serotonin, noradrenaline, NMDA, multitarget } \\
\text { antidepressant, nicotine, oxygen, } \\
\text { monoamines, phosphodiesterase, } \\
\text { benzodiazepine, amino acids, neurokinin }\end{array}$ & $\begin{array}{l}\text { Lind et al.(1919); Alstrup \& Smith }{ }^{(280)} \\
\quad \text { Zimmer \& Luxen }\end{array}$ \\
\hline & $\begin{array}{l}\text { Maximum number of labels/ } \\
\text { structures in stereotaxic } \\
\text { brain atlases }\end{array}$ & 219 & 1105 & $\begin{array}{l}\text { Fairly good. Even though the number of brain } \\
\text { structures in pig atlases is much lower than } \\
\text { that of the human atlas, major structures are } \\
\text { identified and labelled. Moreover, a digital } \\
\text { pig brain atlas is freely available, as in the } \\
\text { human }\end{array}$ & $\begin{array}{l}\text { Talairach \& Tournoux(327); Félix et al } \text { (328); }^{(328)} \\
\quad \text { Lancaster et al. }{ }^{(329)} \text {; Saikali et al. }{ }^{(330)}\end{array}$ \\
\hline
\end{tabular}

TAS1R, taste receptor type 1; TAS2R, taste receptor type 2; MSG, monosodium glutamate; CCK, cholecystokinin; GLP-1, glucagon-like peptide-1; PYY, peptide YY; CT, computed tomography; PET, positron emission tomography; SPECT,

single photon emission computed tomography; MEG, magnetoencephalography; ECoG, electrocorticography; NIRS, near-IR spectroscopy; NMDA, N-methyl-D-aspartate.
The adult body weights for a pig and for a human used in the calculation were 192 and $68 \mathrm{~kg}$ respectively.

T The preference tests in pigs consisted of double-choice tests including two solutions as described in Roura et al. ${ }^{(4)}$. The threshold values for pigs refer to the lowest concentration of the taste active compound tested which resulted in significant $(P<0.05)$ preference over water compared with $50 \%$ (neutral value) (adapted from Roura et al..$^{(4)}$ ). The threshold values for humans refer to the lowest concentration tested following the ascending forced choice triangle test method (Newman \& Keast ${ }^{(331)}$ ), which resulted in significant $(P<0.05)$ detection (E Roura, unpublished results). 


\section{NS Nutrition Research Reviews}

Table 2. Studies on taste receptor and nutrient sensor genes in Sus scrofa compared with Homo sapiens ${ }^{\star}$

\begin{tabular}{|c|c|c|c|c|}
\hline Pig and human gene & Taste (human) & $\begin{array}{l}\text { Pig to human } \\
\text { sequence } \\
\text { homologies: amino } \\
\text { acid/nucleotide }(\%)\end{array}$ & Ligand examples in mammals & Reported sites \\
\hline TAS1R1 & Umami & $84 / 80$ & $\begin{array}{l}\text { L-Glutamate, L-aspartate, L-2-amino-4- } \\
\text { phosphonobutyric acid and potentiated by } \\
\text { IMP and GMP(44,332,333) }\end{array}$ & 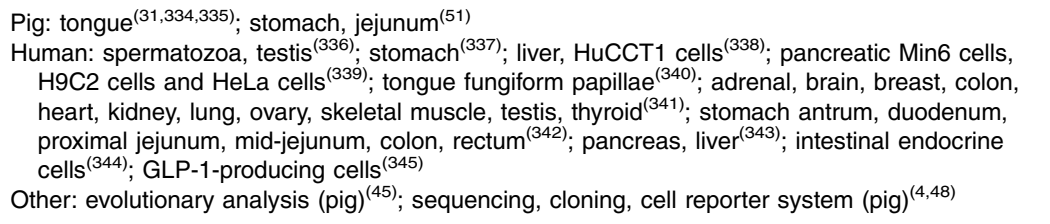 \\
\hline TAS1R2 & Sweet & $84 / 76$ & $\begin{array}{l}\text { Carbohydrates }{ }^{(314)} \text {, for example: sucrose, } \\
\text { saccharin, dulcin and acesulfame- } K^{(346)} \\
\text { aspartame, cyclamate }\end{array}$ & 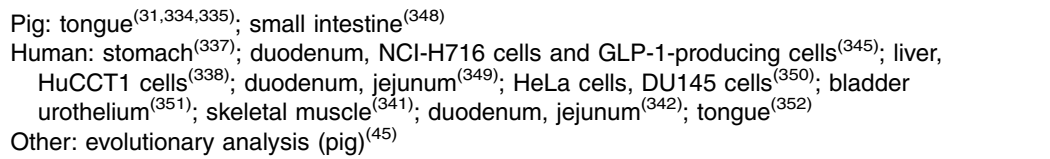 \\
\hline TAS1R3 & $\begin{array}{l}\text { Umami and } \\
\text { sweet }\end{array}$ & $82 / 75$ & $\begin{array}{l}\text { Proteins: L-amino acids (same as TAS1r1 and } \\
\text { TAS1 } 13 \text { 3); } \mathrm{Ca}^{\left({ }^{(353)} ; \text { carbohydrates }^{(314)}\right.}\end{array}$ & 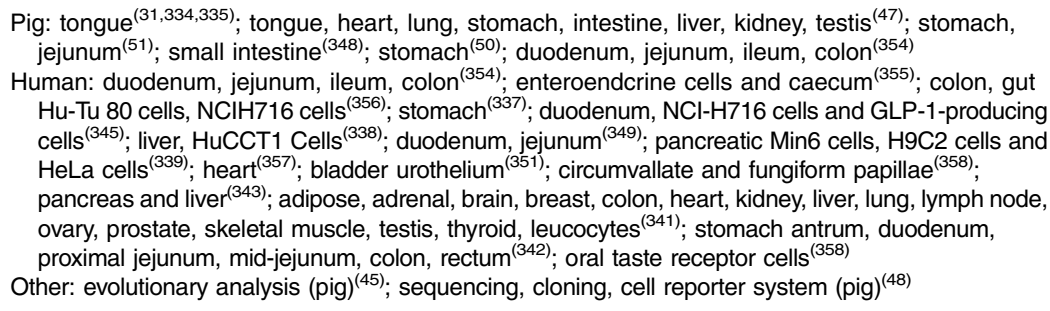 \\
\hline TAS2R1† & Bitter & $71 / 54$ & Amarogentin, arborescin, cascarillin ${ }^{(61)}$ & $\begin{array}{l}\text { Pig: tongue }{ }^{(31,334)} \text {; stomach, jejunum, colon }{ }^{(53)} \\
\text { Human: circumvallate papillae } e^{(359)} \text {; } \text { colon }^{(360)} \text {; heart(357); } \text { airways }^{(361)} \text {; airway smooth muscle }{ }^{(362)} \text {; } \\
\text { brain, kidney, ovary, testis }{ }^{(3414)} ; \text { T lymphocytes }^{(363)} \\
\text { Other: genome analysis }(\mathrm{pig})^{(20)}\end{array}$ \\
\hline TAS2R3 & Bitter & $82 / 72$ & Chloroquine ${ }^{(61)}$ & $\begin{array}{l}\text { Pig: tongue }{ }^{(31,334)} \text {; stomach, jejunum, colon }{ }^{(53)} \\
\text { Human: colon, gut Hu-Tu } 80 \text { cells, NClH716 cells } s^{(356)} \text {; heart }{ }^{(357)} \text {; airways }{ }^{(361)} \text {; airway smooth } \\
\quad \text { muscle } e^{(362)} \text {; stomach }{ }^{(364)} \text {; adrenal, brain, heart, kidney, ovary, testis }{ }^{(341)} ; \text { T lymphocytes }^{(363)} \\
\text { Other: evolutionary analysis (pig) })^{(365)} ; \text { genome analysis }(\mathrm{pig})^{(20)}\end{array}$ \\
\hline TAS2R4 & Bitter & $80 / 70$ & $\begin{array}{l}\text { Amarogentin, arborescin, } \text { artemorin }^{(61)} ; \\
\text { epicatechin }^{(366)}\end{array}$ & $\begin{array}{l}\text { Pig: tongue }{ }^{(31,334)} \\
\text { Human: colon, gut Hu-Tu } 80 \text { cells, NCIH716 cells }{ }^{(356)} \text {; colon }{ }^{(360)} \text {; heart }{ }^{(357)} \text {; airways }{ }^{(361)} \text {; airway } \\
\text { smooth muscle }{ }^{(362)} \text {; adrenal, brain, breast, colon, heart, kidney, lung, lymph node, ovary, testis, } \\
\text { thyroid( }{ }^{(341)} \text {; mixed leucocytes, lymphocytes, monocytes, neutrophils }{ }^{(367)} ; \text { T lymphocytes }^{(363)} \text {; } \\
\text { embryonic kidney cells }{ }^{(368)} \\
\text { Other: evolutionary analysis (pig) }{ }^{(18)} \text {; genome analysis (pig) }{ }^{(20)}\end{array}$ \\
\hline TAS2R7 & Bitter & $83 / 73$ & $\begin{array}{l}\text { Caffeine, quinine }{ }^{(61)} \text {; malvidin-3-glucoside and } \\
\text { procyanidin trimer }{ }^{(366)}\end{array}$ & $\begin{array}{l}\text { Pig: tongue }{ }^{(31,334)} \text {; stomach, jejunum, colon }{ }^{(53)} \\
\text { Human: caecum, NClH716 cells } \\
\text { Other: evolutionary analysis (pig) })^{(18) ;} ; \text { geart }{ }^{(357)} \text {; airways }{ }^{(361)} \text {; banalysis (pig) }{ }^{(20)}\end{array}$ \\
\hline TAS2R9 & Bitter & $82 / 70$ & Ofloxacin, procainamide and pirenzapine ${ }^{(355)}$ & 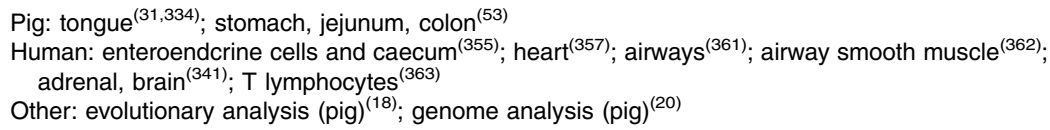 \\
\hline TAS2R10 & Bitter & $84 / 69$ & Absinthin, arborescin, $\operatorname{arglabin}^{(61)}$ & 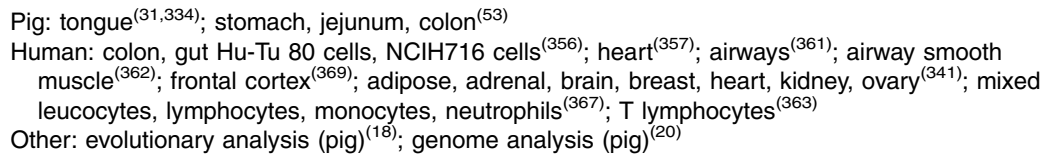 \\
\hline
\end{tabular}




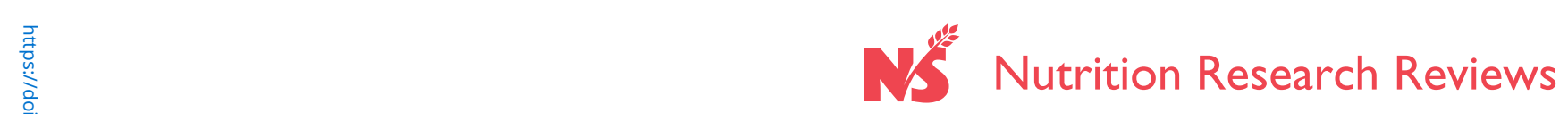

Table 2 Continued

\begin{tabular}{|c|c|c|c|c|}
\hline Pig and human gene & Taste (human) & $\begin{array}{l}\text { Pig to human } \\
\text { sequence } \\
\text { homologies: amino } \\
\text { acid/nucleotide }(\%)\end{array}$ & Ligand examples in mammals & Reported sites \\
\hline TAS2R16 & Bitter & $76 / 61$ & Sinigrin, sodium benzoate, diphenidol ${ }^{(61)}$ & 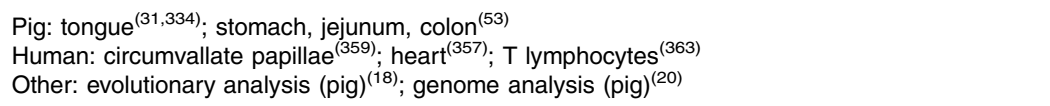 \\
\hline TASR2O & Bitter & $73 / 59$ & Unknown & $\begin{array}{l}\text { Pig: tongue }{ }^{(31,334)} \\
\text { Human: heart }{ }^{(357)} \text {; airway smooth muscle }{ }^{(362)} \text {; colon, cut Hu-Tu } 80 \text { cells, NCIH716 cells (the alias } \\
\text { TAS2R49 is used instead of TAS2R20) } \\
\text { liver, lung, lymph node, ovary, prostate, skeletal muscle, testis, thyroid, leucocytes }{ }^{(341)} \text {; mixed, } \\
\text { leucocytes, lymphocytes, monocytes, neutrophils } \\
\text { Other: genome analysis }(\mathrm{pig})^{(20)}\end{array}$ \\
\hline TAS2R38 & Bitter & $78 / 68$ & $\begin{array}{l}\text { Allylisothiocyanyte, phenylethyl isothiocyanate, } \\
\operatorname{sinigrin}^{(61)}\end{array}$ & 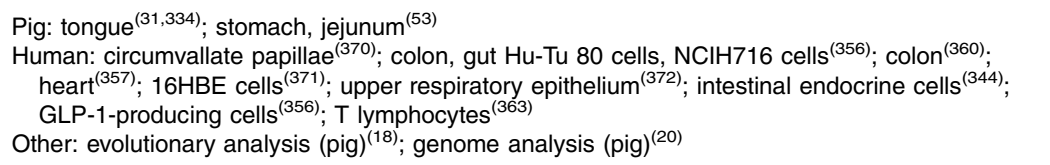 \\
\hline TAS2R39† & Bitter & $82 / 70$ & $\begin{array}{l}\text { Amarogentin, chloramphenicol, colchicine }{ }^{(61)} \\
\text { epicatechin, pentagalloylglucose }\end{array}$ & $\begin{array}{l}\text { Pig: tongue }{ }^{(31,334)} \\
\text { Human: brain }{ }^{(341)} \text {; T lymphocytes }{ }^{(363)} \\
\text { Other: evolutionary analysis }(\mathrm{pig})^{(18)} ; \text { genome analysis }(\mathrm{pig})^{(20)}\end{array}$ \\
\hline TAS2R40† & Bitter & $78 / 62$ & Quinine, chlorpheniramine, dapsone $e^{(61)}$ & $\begin{array}{l}\text { Pig: none reported } \\
\text { Human: colon, gut Hu-Tu cells, NCl-H716 cells } \\
\text { Other: whole genome sequence analysis (pig) })^{(20,46)} \text { T T lymphocytes }\end{array}$ \\
\hline TAS2R41 & Bitter & $79 / 70$ & Chloramphenicol ${ }^{(373)}$ & $\begin{array}{l}\text { Pig: tongue }{ }^{(31,334)} \\
\text { Human: heart }{ }^{(357)} ; \text { T lymphocytes }^{(363)} \\
\text { Other: evolutionary analysis }\left(\text { pig) }{ }^{(18)} ; \text { genome analysis }(\mathrm{pig})^{(20)}\right.\end{array}$ \\
\hline TAS2R42 & Bitter & $76 / 59$ & Unknown & 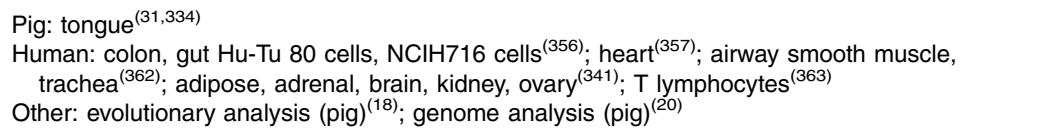 \\
\hline TAS2R60 & Bitter & $77 / 67$ & Unknown & $\begin{array}{l}\text { Pig: tongue }{ }^{(31,334)} \\
\text { Human: colon, gut Hu-Tu } 80 \text { cells, } \mathrm{NClH} 716 \text { cells }^{(356)} \text {; heart } \\
\text { T lymphocytes }{ }^{(363)} \text {; ovary, leucocytes } \\
\text { Other: genome analysis }(\mathrm{pig})^{(20)}\end{array}$ \\
\hline TAS2R134 & Bitter & $\mathrm{N} / \mathrm{A}$ & Unknown & $\begin{array}{l}\text { Pig: tongue }{ }^{(31,334)} \\
\text { Human: not applicable } \\
\text { Other: genome analysis }(\mathrm{pig})^{(20)}\end{array}$ \\
\hline $\begin{array}{l}\text { GPR120, also known } \\
\text { as FFAR4, O3FAR1 }\end{array}$ & $\begin{array}{l}\text { Fatty acid } \\
\text { sensing }\end{array}$ & $88 / 88$ & $\begin{array}{l}\text { Upper range of medium- and long-chain SFA } \\
\text { and unsaturated fatty acids }{ }^{(314,374)}\end{array}$ & $\begin{array}{l}\text { Pig: tongue }{ }^{(31,334)} \text {; stomach, jejunum, colon }{ }^{(53)} \text {; duodenum, jejunum, ileum, colon }{ }^{(354)} \\
\text { Human: brain, thymus, lung, ileum, colon, rectum, spleen, kidney, adrenal gland }{ }^{(374)} \text {; duodenum, } \\
\text { jejunum, ileum, colon }{ }^{(354)} \text {; adipose tissue, stomach, small intestine, colon and lung }{ }^{(375)} \text {; stomach } \\
\text { antrum, duodenum, proximal jejunum, mid-jejunum, colon, rectum } \\
\text { Other: next-generation sequence analysis }\left(\text { pig) }{ }^{(376)}\right.\end{array}$ \\
\hline $\begin{array}{l}\text { GPR } 40, \text { also known as } \\
\quad \text { FFAR1 }\end{array}$ & $\begin{array}{l}\text { Fatty acid } \\
\text { sensing }\end{array}$ & $84 / 85$ & $\begin{array}{l}\text { Shorter medium- and long-chain SFA and } \\
\text { unsaturated fatty acids }{ }^{(314,377,378)}\end{array}$ & $\begin{array}{l}\text { Pig: tongue }{ }^{(31,53,334)} \\
\text { Human: pancreatic islets }{ }^{(379)} \text {; stomach antrum, duodenum, proximal jejunum, mid-jejunum, colon, } \\
\text { rectum }^{(342)}\end{array}$ \\
\hline
\end{tabular}


Table 2 Continued

\begin{tabular}{|c|c|c|c|c|}
\hline Pig and human gene & Taste (human) & $\begin{array}{l}\text { Pig to human } \\
\text { sequence } \\
\text { homologies: amino } \\
\text { acid/nucleotide (\%) }\end{array}$ & Ligand examples in mammals & Reported sites \\
\hline $\begin{array}{l}\text { GPR43, also known as } \\
\quad \text { FFAR2 }\end{array}$ & $\begin{array}{l}\text { Fatty acid } \\
\text { sensing }\end{array}$ & $86 / 84$ & $\begin{array}{l}\operatorname{SCFA}^{(314,380,381)} \text { (for example, acetate, } \\
\text { propionate and butyrate) }\end{array}$ & 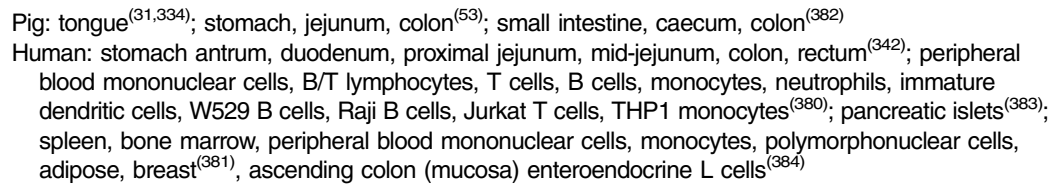 \\
\hline GPR41 aka FFAR3 & $\begin{array}{l}\text { Fatty acid } \\
\text { sensing }\end{array}$ & $75 / 79$ & $\begin{array}{l}\text { SCFA }{ }^{(314,380,381)} \text { (for example, propionate, } \\
\text { butyrate, acetate) }\end{array}$ & $\begin{array}{l}\text { Pig: tongue }{ }^{(31,334)} \text {; small intestine, caecum, colon }{ }^{(382)} \\
\text { Human: stomach antrum, duodenum, proximal jejunum, mid-jejunum, colon, rectum }{ }^{(342)} \text {; bone } \\
\text { marrow, placenta, prostate, pancreas, adipose, peripheral blood mononuclear cells, spleen, } \\
\text { intestine, stomach, muscle, kidney, fetal liver, liver, lung, heart, pituitary, brain }{ }^{(380)} \text {; pancreatic } \\
\text { islets }{ }^{(383) ;} \text {; thymus, spleen, lymph node, bone marrow, peripheral blood mononuclear cells, dendritic } \\
\text { cells, polymorphonuclear cells, small intestine, adipose, breast }{ }^{(381)} \text {; colonic mucosa }{ }^{385)}\end{array}$ \\
\hline GPR84 & $\begin{array}{l}\text { Fatty acid } \\
\text { sensing }\end{array}$ & $88 / 90$ & Medium-chain fatty acids ${ }^{(314)}$; capric acid $^{(386)}$ & $\begin{array}{l}\text { Pig: tongue }{ }^{(31,334)} \\
\text { Human: brain, fetal brain, trachea, lung, stomach, small intestine, colon, pancreas, liver, fetal liver, } \\
\text { kidney, fetal kidney, fetal heart, thyroid, thymus, fetal thymus, spleen, fetal spleen, bone marrow, } \\
\text { peripheral leucocytes, placenta, bladder, prostate, uterus, adrenal gland, mammary gland, salivary } \\
\text { gland, adipose } \mathrm{s}^{(386)} \text {; stomach antrum, duodenum, proximal jejunum, mid-jejunum, colon, rectum }{ }^{(342)}\end{array}$ \\
\hline$C D 36$ & No taste & $86 / 83$ & Long-chain fatty acids ${ }^{(387)}$ & $\begin{array}{l}\text { Pig: tongue } \mathrm{i}^{(388,389)} ; \text { monocytes }^{(390)} \\
\text { Human: tongue }^{(388)} ; \text { monocytes }^{(390)}\end{array}$ \\
\hline GPRC6A & No taste & $90 / 88$ & $\begin{array}{l}\text { L-Amino acids (subclass: basic, polar, } \\
\text { aliphatic) }{ }^{(314,332,391)}\end{array}$ & $\begin{array}{l}\text { Pig: tongue }{ }^{(31,334)} \text {; stomach antrum }{ }^{(52)} \\
\text { Human: embryonic kidney cells }{ }^{(332)} \text {; stomach antrum }{ }^{(52)} \text {; brain, lung, liver, heart, kidney, pancreas, } \\
\text { skeletal muscle, placenta, spleen, ovary, testis, leucocytes }\end{array}$ \\
\hline $\begin{array}{l}\text { mGluR1, also known } \\
\text { as GRM1 }\end{array}$ & $\begin{array}{l}\text { Umami } \\
\text { candidate }\end{array}$ & 92/99 & L-Glutamate ${ }^{(393)}$ & $\begin{array}{l}\text { Pig: tongue }{ }^{(31,334)} \text {; stomach, jejunum }{ }^{(51)} \\
\text { Human: brain cortex and cerebellum }{ }^{(394)} \text {; melanoma cells }{ }^{(395)} \text {; melanocytes }{ }^{(396)}\end{array}$ \\
\hline mGluR4 aka GRM4 & $\begin{array}{l}\text { Umami } \\
\text { candidate }\end{array}$ & 93/93 & Tricyclic thiazolopyrazole derivatives ${ }^{(397)}$ & $\begin{array}{l}\text { Pig: tongue }{ }^{(31,334)} \text {; stomach, jejunum }{ }^{(51)} \\
\text { Human: stomach antrum, duodenum, proximal jejunum, mid-jejunum, colon, rectum }{ }^{(342)}\end{array}$ \\
\hline CASR & No taste & $91 / 94$ & $\begin{array}{l}\mathrm{Ca}^{2+} ; \text { proteins: L-amino acids } \\
\text { subclass: basic, acidic, aliphatic, aromatic, } \\
\text { branch chain }\end{array}$ & 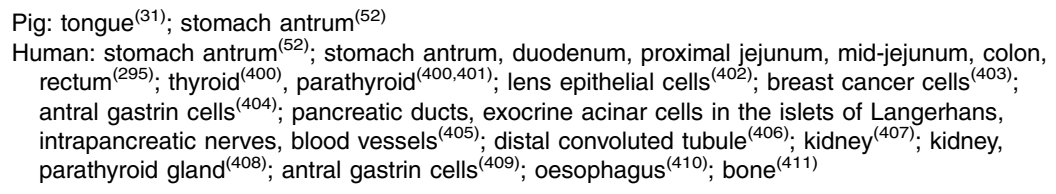 \\
\hline $\begin{array}{l}\text { GPR92, also known as } \\
\quad \text { GPR93, LPAR5 }\end{array}$ & No taste & $84 / 77$ & Proteins (peptones) $)^{(314)}$ & $\begin{array}{l}\text { Pig: tongue }{ }^{(31,334)} \text {; stomach antrum }{ }^{(52)} \\
\text { Human: stomach antrum } \\
\text { jejunum, colon, rectum }{ }^{(542)} \text { mast cells }{ }^{(412)} \text {; stomach antrum, duodenum, proximal jejunum, mid- }\end{array}$ \\
\hline \multicolumn{3}{|c|}{ 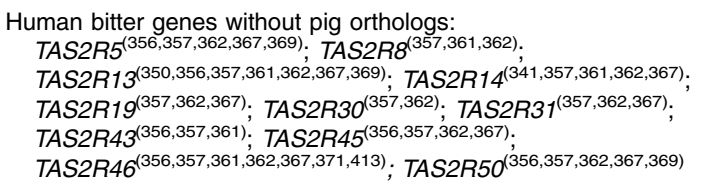 } & Various $^{(61,355,366,373)}$ & $\begin{array}{l}\text { Airway smooth muscle, trachea }{ }^{(362)} \text {; frontal cortex }{ }^{(369)} \text {; colon, gut Hu-Tu cells, NCI-H716 cells; } \\
\text { airways }{ }^{(356) ;} \text { HeLa cells, DU145 cells } s^{(361)} \text {; heart }{ }^{(357)} ; 16 \mathrm{HBE} \text { cells }{ }^{(371)} \text {; bone marrow stromal- } \\
\text { derived cells, vascular smooth muscle cells }{ }^{(413)} ; \text { mixed leucocytes, lymphocytes, monocytes, } \\
\text { neutrophils; leucocytes }{ }^{(367)}\end{array}$ \\
\hline
\end{tabular}

TAS1R, taste receptor type 1; TAS2R, taste receptor type 2; IMP, inosine monophosphate; GMP, guanosine monophosphate; GLP-1, glucagon-like peptide-1.

* The homology percentage for pigs compared with humans was calculated between the amino acid sequences and between the nucleotide sequences for each gene.

the porcine gene TAS2R134 has no known human homolog (Da Silva et al. ${ }^{(31)}$ ). 
(glutamic and aspartic), whereas pigs recognise a wider array of $\mathrm{L}-\mathrm{AA}{ }^{(51,54)}$. The strong preference for non-glutamic AA in pigs is an important differential feature compared with humans. However, the umami receptor in laboratory rodents responds to an even wider array of L-AA compared with pigs ${ }^{(4)}$.

Umami tastants in pigs, for example, monosodium glutamate, either alone or in combination with nucleotides, and some sweet tastants, stimulate nerve fibres identified with umami sensing ${ }^{(56)}$. Umami and sweet compounds are both perceived by dimeric taste receptors (TR) sharing one common receptor $\mathrm{T} 1 \mathrm{R} 3^{(58)}$

Characterisation of the umami dimer, TAS1R1/TAS1R3, and the glutamate receptor, mGluR1, revealed higher homologies of these porcine genes with the human orthologs compared with laboratory rodents ${ }^{(4,35)}$. Studies of divergences and similarities in gene structure and expression between pigs and humans for the whole TASR repertoire showed high homology for the TAS1R subfamily coding for carbohydrates, AA and FA, but low homology for the TAS2R subfamily coding for bitter tastes ${ }^{(31)}$. Recent publications indicate the pig has sixteen and the human twenty-five TAS2R genes ${ }^{(25,31)}$. It may be speculated that the similarity in TAS1R gene structure between pigs and humans is consistent with the theory of parallel evolution, where both species are omnivorous and consumed diets with similar nutrient profiles. The lower number of TAS $2 R$ genes in pigs may indicate a higher resilience of pigs to bitter dietary compounds ${ }^{(20)}$. It has been suggested that the TAS2R receptors unique to humans tend to have a narrow specificity and may not have food-related significance particularly in light of their extra-oral expression ${ }^{(59)}$. Da Silva et al. ${ }^{(31)}$ also reported a high incidence of non-synonymous polymorphisms in the porcine TAS2R repertoire when comparing fourteen different pig breeds across the globe. These findings are consistent with the view that bitter taste gene diversity is an adaptation within animal species $^{(18,60)}$, including humans ${ }^{(61)}$, to their specific ecosystems. The porcine TAS2R is not a good model for the study of bitter agents in humans. However, the global widespread nature of pig breeds following human expansion may represent a unique model to study the role of taste in the adaptation to specific geo-ecosystems

One limitation for using the pig as a model for humans to study taste sensitivity is a difference in methodology used between the two species. Threshold nutrient concentrations are determined in pigs using preference tests, often compared with water, whereas recognition thresholds are used in human studies. Compared with a recognition threshold, a preference threshold may require higher doses. Results from these two types of comparisons suggest that pigs are more sensitive to citric acid and SUC, but less sensitive to $\mathrm{NaCl}$ than humans ${ }^{(4,62)}$. In addition, pigs and humans show strong discrepancies in the responses to most high-intensity sweeteners tested to date ${ }^{(48,49)}$.

\section{Conclusion on using the pig as a model for human nutritional chemosensing studies}

The chemosensing anatomy appears to be similar for pigs and humans with a similar ratio of taste buds in the mouth to mature body weight and the location of sensors throughout the GIT and other organs. The two species also show similarity in studies related to tasting simple sugars (sweet), glutamate (umami) and citric acid (sour). In contrast to humans, pigs do not have the same ability to taste some high-intensity sweeteners or non-glutamate $\mathrm{AA}$ and appear less sensitive to $\mathrm{NaCl}$ (salt). Overall, pigs are an excellent model for humans, when based on carbohydrate-, AA- and FA-sensing mechanisms. In contrast, the bitter sensory system of pigs and humans is diverse and characterised by species-specific features evolving from the adaptation to different ecosystems. Studying gene expression in human tissues can be difficult, particularly when using well-controlled nutrition intervention studies. The similarity in nutrient receptors and taste sensitivities between pigs and humans creates the opportunity to use the pig as a model in place of rodents for behavioural studies into chemosensing.

\section{Endocrine regulation of food intake: gut-nutrient sensing and gut-brain communication}

Sensory cells expressing TR in the GIT are part of the enteroendocrine system. Signalling of appetite or satiety in the gut can be both GIT hormone and nutrient specific ${ }^{(63)}$. The release of GIT hormones is activated by fasting or food intake via intestinal receptors that respond to mechanical and/or chemical stimulation ${ }^{(64)}$ including $\mathrm{TR}^{(65)}$. Over forty GIT hormones have been identified with specific bioactivity ${ }^{(66)}$ of which eight GIT hormones (cholecystokinin (CCK), glucagon-like peptide-1 (GLP-1), oxyntomodulin, peptide YY (PYY), apoA-IV, gastrinreleasing peptide and neuromedin $\mathrm{B}$, gastric leptin and ghrelin) have been implicated in the regulation of food intake in mammals ${ }^{(67)}$. This section focuses on the following four hormones specifically released by the stomach and/or small and large intestine with published results in humans and pigs: CCK, GLP-1, PYY and ghrelin. The importance of these four GIT hormones in appetite regulation has been reviewed by Perry \& Wang ${ }^{(68)}$. In the context of nutrient-induced release of satiety hormones it has been reported by Geraedts et al. ${ }^{(69)}$ that the release of CCK and GLP-1 in response to dietary proteins differs substantially between humans and rats, underlining the need for alternative, more human-like, animal models to study food intake regulation.

Once GIT hormones are released, they may exert their action via a neural or an endocrine route. The neural route involves binding of GIT hormones to local GIT receptors and subsequent signal transduction via afferent fibres of the abdominal vagal nerve to the brain. The endocrine route involves systemic transport of GIT hormones to the brain and by binding to brain receptors present in the area postrema, a brain structure serving as an interface between blood and brain, or by crossing the blood-brain barrier (BBB) and subsequent binding to receptors in specific brain regions. For proper translational research from pig to human, it is important that the kinetics of GIT hormones in blood follow a similar profile. For instance, the kinetics of circulating GLP-1 are similar in pigs and humans, but different in rats ${ }^{(70)}$. This difference between the species is probably caused by the rapid inactivation of GLP-1 by circulating protease dipeptidyl peptidase-4 (DPP-4), which is more active in rats than in pigs and humans. 
Similarities and differences of nutrient-induced release of satiety hormones and endocrine gut-brain communication in pigs and humans

Cholecystokinin. Depending on the amount and composition of the diet, CCK is secreted by the I cells in the duodenal and jejunal mucosa and also by neurons in the enteric nervous system. CCK contributes to satiation and satiety effects. The major effects of CCK are stimulation of gall bladder contraction, delay of gastric emptying and stimulation of pancreatic secretion $^{(63)}$. In pigs, CCK release is stimulated by a mixed meal from fasting to postprandial ( $30-120 \mathrm{~min}$ ) concentrations going from about $10 \mathrm{pmol} / \mathrm{l}$ to about $30 \mathrm{pmol} / \mathrm{l}$, respectively, with a faster response when diets are enriched with starch than with fat ${ }^{(71)}$. Clutter et al. ${ }^{(72)}$ measured plasma CCK-8 in pigs, at fasting about $2 \mathrm{pmol} / \mathrm{l}$ increasing to $10 \mathrm{pmol} / \mathrm{l}$ at mixed meal feeding whereas Ripken et al. ${ }^{(73)}$ reported concentrations of $0.5 \mathrm{pmol} / \mathrm{l}$ and $2 \mathrm{pmol} / \mathrm{l}$ for fasting and postprandial, respectively. All experiments showed a 2 - to 5 -fold increase in plasma CCK-8 concentrations after mixed meal feeding. Another study in pigs $^{(74)}$, using intraduodenal fat infusion, showed plasma CCK concentrations of approximately $5 \mathrm{pmol} / 1$ both prior and following fat infusion. CCK release was higher to long-chain FA than to medium-chain TAG. In humans, CCK release is mostly stimulated by the presence of dietary protein, whereas carbohydrate provides a weaker stimulus ${ }^{(75)}$. To our knowledge, the effect of dietary protein on plasma CCK secretion has not been investigated to date in pigs. Plasma CCK concentrations are similar in pigs and humans, on average for humans at fasting $2 \mathrm{pmol} / \mathrm{l}$ and at feeding $10 \mathrm{pmol} / \mathrm{l}^{(76-79)}$. In both species the magnitude of the CCK response is dependent on the composition of the meal. The effects of single macronutrients or combinations thereof on CCK release have not been investigated systematically in humans or pigs. The pig is a valid model to investigate these relationships.

Anika et $a l .{ }^{(80)}$ administered CCK intravenously at a rate of $0.2 \mathrm{nmol} / \mathrm{kg}$ per min for total doses of $0.4,0.8,1.7$ and $3.4 \mathrm{nmol} / \mathrm{kg}$ to pigs. The lowest dose of CCK reduced food intake by $13 \%$ and the highest dose by $94 \%$. Houpt ${ }^{(81)}$ showed that intravenous (iv) CCK-8 (the synthetic and bioactive part of the CCK molecule) infusion to pigs of 14,28 and $56 \mathrm{pmol} / \mathrm{kg}$ per min decreased meal size in a dose-dependent manner. A dose of $28 \mathrm{pmol} / \mathrm{kg}$ per min reduced food intake by 30-40 \%. Similar results were found by Baldwin et al. ${ }^{(82)}$ who studied hungry pigs working for food, thirsty pigs responding for water, and non-deprived pigs working for SUC. In this study CCK produced significant dose-related decreases in response rates for all three conditions.

Nutrients exert much of their effects through the CCK-1 receptor ${ }^{(83)}$. There are two regions where CCK acts to produce satiety: the nucleus tractus solitarius in the hindbrain and the medial-basal hypothalamus ${ }^{(84)}$. CCK acts both at CCK-1 receptors beyond the $\mathrm{BBB}$ and by a CCK-1 receptor-mediated mechanism involving abdominal vagal nerves to inhibit food intake $^{(84)}$. CCK-1 antagonists, such as devazepide (DVZ), are commonly used in pig appetite and satiety studies ${ }^{(85)}$. DVZ easily passes the BBB following iv administration inducing a dose-related increase in food intake at doses ranging from
17.5 to $140 \mu \mathrm{g} / \mathrm{kg}$ with maximum increases occurring at about $70 \mu \mathrm{g} / \mathrm{kg}^{(86-88)}$. Arterial injection of DVZ $(0 \cdot 1 \mathrm{mg} / \mathrm{kg})$ in pigs ${ }^{(89)}$ abolished the inhibition of food intake to duodenal infusion of emulsified fat and monoacylglycerols. However, it did not alter the inhibition of intake in response to oleic acid, to glycerol or to GLU, suggesting that monoacylglycerol-induced CCK secretion is mainly responsible for the satiety resulting from duodenal fat infusion in the pig. Baldwin \& Sukhchai ${ }^{(90)}$ reported that intracerebroventricular (icv) injection of DVZ $(100 \mu \mathrm{g})$ before the administration of $1 \mu \mathrm{g}$ CCK abolished the inhibition of GLU intake produced by CCK in pigs. However, DVZ itself had no effect on GLU intake. In a study by Farmer et al. ${ }^{(91)}$, pigs were fasted for $24 \mathrm{~h}$, injected intravenously with DVZ at $70 \mathrm{mg} / \mathrm{kg}$ and subsequently subjected to a feed motivation test (operant conditioning). The number of pushes, duration of eating and amount of feed eaten during the feed motivation test were all increased by fasting, and were further increased by DVZ injection, indicating that CCK induces satiation in pigs. An alternative CCK receptor antagonist used in pigs is 2-NAP (2naphthalenesulfanyl-1-aspartyl-2-(phenethyl) amide), which does not cross the BBB. Baldwin et al. ${ }^{(92)}$ revealed that iv administration (20 or $40 \mathrm{mg} / \mathrm{kg}$ ) of NAP injected before iv administration of CCK- $8(1 \mu \mathrm{g} / \mathrm{kg})$ abolished the inhibitory effects of CCK-8 on food intake in hungry pigs. Also, NAP abolished the inhibitory effects of CCK- 8 on food intake in hungry pigs after icv injection of both compounds. Overall, these results indicate that endogenous CCK is involved in the regulation of satiety in pigs, in a way which is similar to what is known in humans ${ }^{(93)}$, albeit the pig offers the possibility to conduct invasive mechanistic studies on CCK action.

Glucagon-like peptide-1. GLP-1 is mostly produced by the $\mathrm{L}$ cells in the distal small intestine and colon and contributes to satiety. It performs a variety of functions in the body such as inhibiting acid secretion and gastric emptying, while increasing insulin secretion from the pancreas in a GLU-dependent manner ${ }^{(94)}$. The secretion of GLP-1 is mediated by indirect, duodenal activated neurohumoral mechanisms, as well as by direct contact of nutrients with the distal small intestine ${ }^{(82)}$. Souza da Silva et al. ${ }^{\left({ }^{95}\right)}$ showed that fasting plasma GLP-1 concentrations of $15 \mathrm{pmol} / 1$ rose to $35 \mathrm{pmol} / 1 \mathrm{~h}$ after the beginning of a complete mash feed. Hooda et al. ${ }^{(96)}$ showed that fasting plasma GLP-1 concentrations in pigs were approximately $8 \mathrm{pmol} / \mathrm{l}$ and rose postprandial to $20 \mathrm{pmol} / \mathrm{l}$, 1-2 $\mathrm{h}$ after initiation of the mixed-nutrient meal. The rise of plasma GLP-1 in response to intraduodenal infusion of GLU, fat and GLU-fat in pigs was modest $(+5 \mathrm{pmol} / \mathrm{l})$ for GLU and intermediate $(+10 \mathrm{pmol} / \mathrm{l})$ for fat, while the effect of combining GLU and fat was additive $(+15 \mathrm{pmol} / \mathrm{l})^{(97)}$. To our knowledge, the effect of dietary protein on plasma GLP-1 secretion has not been investigated to date in pigs. In general, the GLP-1 responses to fasting/feeding in pigs are comparable with those in humans, with fasting concentrations of about $13 \mathrm{pmol} / 1$ rising to $30-40 \mathrm{pmol} / 1$ postprandial ${ }^{(78,98,99)}$.

Although GLP-1 can cross the BBB, several studies suggest that peripheral GLP acts to reduce food intake primarily via activation of the vagal afferent nerve ${ }^{(100)}$. Little information is 
available on the effect of GLP-1 on food intake in pigs. Ribel et $a l .{ }^{(101)}$ showed that administration of a synthetic GLP-1 analogue reduced gastric emptying and therefore may induce satiation in pigs. In general, the pig is recognised as being a good model for studying human conditions ${ }^{(102)}$, and in the case of GLP-1 analogues, it has found to be predictive of clinical findings in both reduction of hyperglycaemia (through improved insulin secretion and decreased glucagon secretion) and body-weight loss (through reduced gastric emptying and increased satiety) ${ }^{(103)}$. The icv administration of GLP-1 inhibited feeding in fasted rats and was counteracted by the icv injection of exendin 9-39, a GLP-1 receptor antagonist ${ }^{(104)}$. No data are available in pigs.

Peptide $Y Y$. PYY is an anorexigenic hormone. It is a member of the pancreatic polypeptide (PP)-fold family of peptides. It is secreted by the L cells of the distal small-intestinal mucosa. The PYY-containing endocrine cells are found in highest numbers in the lower small intestine and colon. The gastrointestinal functions of PYY include inhibition of gastric acid and pepsin secretion, inhibition of pancreatic exocrine secretion, delay of gastric emptying and inhibition of jejunal and colonic motility ${ }^{(105)}$. The secretion of PYY is stimulated by the presence of nutrients in the intestine. In humans, fats provide the strongest stimulus followed by carbohydrates and protein ${ }^{(106)}$. Little is known on the effects of intestinal nutrient loads on PYY secretion in pigs. Plasma PYY concentrations were higher (500 pmol/l) in ad libitum-fed pigs compared with fasted pigs $(200 \mathrm{pmol} / \mathrm{l})^{(107)}$. On the other hand, Souza da Silva et al. ${ }^{(95)}$ showed that fasting plasma PYY concentrations were approximately $700-800 \mathrm{pmol} / \mathrm{l}$, showing no response to a mixednutrient meal. Plasma PYY concentrations are lower in humans, ranging from $30 \mathrm{pmol} / \mathrm{l}$ at fasting up to $116 \mathrm{pmol} / \mathrm{l}$ after an intestinal nutrient $\operatorname{load}^{(77,106)}$. In the fast-refed condition, both single bolus injection ( $30 \mathrm{mg} / \mathrm{kg}$ body weight) and iv infusion $(0.25 \mathrm{mg} / \mathrm{kg}$ per min) of PYY3-36 (the synthetic and bioactive part of the PYY molecule) suppressed feed intake in pigs ${ }^{(107)}$, suggesting that circulating PYY3-36 influences satiety and contributes to the termination of a meal such as in humans ${ }^{(68)}$.

Ghrelin. Ghrelin is an orexigenic intestinal hormone. In pigs, it is mostly produced in the oxyntic and cardiac gland and less commonly in the pyloric glands of the stomach ${ }^{(108)}$, with a similar pattern to that in humans ${ }^{(109)}$. Ghrelin functions as a neuropeptide signal that reduces satiety and increases hunger. Govoni et $a l .{ }^{(108)}$ and Zhang et al. ${ }^{(110)}$ showed that fasting increases plasma ghrelin concentrations from 10-25 to $50 \mathrm{pmol} / 1$ in prepubertal gilts and weanling pigs, respectively. Ghrelin in pigs responded to changes in energy balance and the concentrations increased during fasting from approximately 25 to $75 \mathrm{pmol} / \mathrm{l}^{(108,111)}$. Barretero-Hernandez et al. ${ }^{(65)}$ reported postprandial plasma ghrelin concentrations of $6 \mathrm{pmol} / \mathrm{l}$, increasing to $10 \mathrm{pmol} / 1$ at fasting in pigs. Scrimgeour et al. ${ }^{(112)}$ suggested that the dynamics in plasma ghrelin concentrations in the pig appear to be strongly influenced by prolonged fasting and change from $15 \mathrm{pmol} / \mathrm{l}$ (feeding) to $100 \mathrm{pmol} / \mathrm{l}$ (fasting). These ghrelin responses to fasting/feeding are comparable with those observed in humans ${ }^{(78,113)}$. However, the concentrations in humans are higher, being approximately $150 \mathrm{pmol} / \mathrm{l}$ postprandial and $250 \mathrm{pmol} / \mathrm{l}$ at fasting.

Salfen et al. ${ }^{(114)}$ showed that there was an increase in body weight of weanling pigs given exogenous ghrelin chronically, suggesting that feeding behaviour was influenced by the treatment. Ghrelin stimulates food intake in humans too. However, in vagotomised patients, ghrelin does not increase food intake, suggesting that an intact vagus nerve is required for exogenous ghrelin to increase appetite in humans ${ }^{(115)}$. No pig studies have been conducted addressing the contribution of the vagus nerve to the orexogenic action of ghrelin.

\section{Conclusions on nutrient-induced secretion of satiety hormones and on endocrine gut-brain communication in pigs and humans}

Basal or fasting plasma concentrations of CCK and GLP-1 are similar in pigs and humans. The nutrient-induced increase of CCK and GLP-1 concentrations is also similar in both species. Plasma CCK increases postprandial 2- to 5-fold, whereas GLP-1 increases 3 -fold in pigs and in humans. Therefore, pigs are a useful model for the investigation of the effects of single (macro) nutrients or combinations of nutrients on CCK- and GLP-1 release. Fasting and postprandial plasma concentrations of PYY in pigs are 10- to 20-fold higher compared with humans. The PYY response of pigs to feeding or intestinal infusion of nutrients (in terms of percentage increase of PYY concentration) seems to be smaller than in humans. For ghrelin the reverse is true; humans show 2- to 5-fold higher plasma concentrations than pigs. The responses of ghrelin to fasting or feeding are comparable in pigs and humans: 2- to 3-fold increases of ghrelin at fasting as compared with fed conditions. The relevance of the pig as a model for human GIT hormone dynamics seems therefore CCK and GLP-1 > ghrelin > PYY.

Many pig studies support the human-like action of CCK on food intake regulation, but far fewer studies are available on the actions of GLP-1, PYY and ghrelin. Nevertheless, for GLP-1, PYY and ghrelin, human-like actions on food intake regulation have been reported in pigs ${ }^{(116)}$. Therefore, from an endocrine perspective, the pig is a suitable large animal model for the study of the humoral pathways of gut-brain communication as summarised in Table 1.

\section{Gastrointestinal tract permeability and detoxification systems}

\section{Current outline of research in nutrition, gut-barrier and defence systems}

An important aspect of the GIT function refers to metabolic disorders and obesity, which in humans are partially driven by excessive intake of high-energy diets and may be programmed early in life ${ }^{(117,118)}$. Unbalanced, high-energy/fat and low-fibre diets may alter GIT permeability, allowing translocation of gut pro-inflammatory microbial-associated molecular patterns (MAMP) such as lipopolysaccharide (LPS) into the body and the development of metabolic inflammation, as demonstrated 
in mice ${ }^{(119)}$. These MAMP may then promote adipose tissue expansion, insulin resistance, metabolic disturbances and fat deposition.

The GIT is complex, comprising the mucus, the epithelial monolayer and the enteric immune system that includes intestinal epithelial cells ${ }^{(120)}$. The intestinal epithelium participates in digestion and absorption, while tightly restricting body access of deleterious components. Passage of compounds across the epithelium is mainly regulated by tight paracellular junctions and by macromolecular uptake transcellular mechanisms ${ }^{(121)}$. LPS entry can be transcellular via the chylomicron pathway, following FA absorption, but also paracellular when the transcellular route is altered ${ }^{(122)}$. These mechanisms appear relevant to stress-related diseases (for example, gut chronic inflammation), the metabolic syndrome and obesity in humans ${ }^{(123-125)}$

Besides permeability, the intestinal mucosa is equipped with defence systems including epithelial intestinal alkaline phosphatase (IAP) and inducible heat shock proteins (HSP). IAP is produced by the enterocyte and acts as a major antiinflammatory enzyme through two mechanisms: detoxification, by dephosphorylating pro-inflammatory MAMP (for example, LPS), and control of local (and systemic) inflammation through a down-regulation of the Toll-like receptor 4-triggered NF- $\kappa \mathrm{B}$ activation and of inflammatory cytokine production ${ }^{(126)}$. Intestinal epithelial cells are chronically exposed to a harsh environment and toxic substances and they have developed inducible HSP (HSP27, HSP70) as anti-inflammatory and antioxidant cytoprotection mechanisms ${ }^{(127)}$. Inducible HSP are involved in intracellular protein trafficking, with many functional implications, including protection against potentially invasive compounds and organisms ${ }^{(127)}$. Inducible HSP are produced in response to diverse microbial components and related metabolites (for example, LPS, butyrate) in vitro ${ }^{(120)}$. However, in vivo data are scarce.

Alterations in the function of the intestinal barrier and defence systems may lead to chronic inflammatory diseases ${ }^{(128)}$. Conversely, dietary approaches aimed at reducing intestinal permeability and/or stimulating IAP and inducible HSP may contribute to prevent or treat such diseases.

This section summarises comparisons between the pig and the human for intestinal physiology of permeability and its neuroimmune regulation, detoxification and defence systems, their dietary modulation and their early programming.

\section{Similarities between pigs and humans}

The pathophysiology, molecular basis and neuroimmune regulation of the intestinal barrier when under stress have been described for rodent models ${ }^{(121)}$. In summary, the mechanism involves hypothalamic corticotropin-releasing factor (CRF), central and peripheral CRF receptors, degranulation of mucosal mast cells and release of various bioactive mediators. Large quantitative inter-species differences exist for intestinal permeability of small, medium-size and large molecules. Notably, pigs are closer to humans than rodents for both trans- and para-cellular permeability values ${ }^{(129,130)}$. Intestinal permeability regulation in pigs also involves enteric nerve activation, CRF, mast cells and released tryptase and TNF- $\alpha^{(120,131,132)}$. Data are limited in humans, but they indicate essentially the same regulations ${ }^{(130,133)}$.

MAMP detoxification function by IAP is conserved across species $^{(134)}$. IAP is highly expressed along the villous epithelium of the small intestine in pigs ${ }^{(135)}$ and humans ${ }^{(136)}$. IAP activity is 10- to 15-fold higher in the distal ileum compared with proximal colon in both species ${ }^{(136,137)}$. In pigs, IAP activity is drastically reduced after weaning and may cause postweaning intestinal alterations ${ }^{(135)}$. Depressed IAP is also suspected in various inflammatory diseases in humans ${ }^{(126)}$. Administration of exogenous IAP has strong anti-inflammatory effects in both species ${ }^{(126,136,138,139)}$. Plasma LPS is a marker of metabolic inflammation in humans ${ }^{(140)}$. Intake of saturated fat is consistently reported to increase plasma LPS in humans ${ }^{(141)}$ and pigs ${ }^{(142)}$, intestinal transport of LPS in pigs ${ }^{(142)}$ and plasma IAP in humans ${ }^{(143)}$.

\section{Differences between pigs and humans, or pig studies with no equivalent in humans}

Differences exist between humans, pigs and rodents for IAP gene copies ( $n$ 1, 2 and 2, respectively) and their chromosome location $^{(134)}$. IAP distribution along the small intestine is opposite between pigs and rodents, the former having higher IAP activity in the ileum and lower in the duodenum compared with rodents ${ }^{(126,144)}$. The distribution of IAP along the human intestine is yet to be elucidated. Human cell line $\mathrm{CacO} 2$ and porcine IPEC-I display inducible HSP (for example, HSP70) ${ }^{(145,146)}$. However, data on intestinal HSP25 or HSP70 in human tissues are lacking. As a prototypic example of dietary modulation of intestinal defence systems, L-glutamine supplementation has been shown to improve the morphological integrity and barrier function of the intestines in humans ${ }^{(147)}$ and pigs ${ }^{(148,149)}$. However, these studies are difficult to compare due to many differences in experimental conditions. $\mathrm{Zn}$ is a key element for intestinal and body homeostasis. One in vitro study with human (Caco2) and porcine (IPEC-J2) intestinal epithelial cells revealed cell line differences in permeability and Hsp70 responses to $\mathrm{Zn}$, suggesting inter-species differences ${ }^{(150)}$. However, in vivo data in humans are lacking.

The concept of 'developmental origin of health and disease', linking early-life malnutrition (deficiency or excess) to metabolic diseases was formulated two decades ago ${ }^{(151)}$. The effects of nutrition in early life on gene expression and potential longterm effects have become a discipline of high interest in human $^{(152,153)}$ and animal ${ }^{(21,154)}$ models. However, data on how early-life gene programming may affect intestinal function and defence systems are limited in humans ${ }^{(155,156)}$. Various dietary components, including protein, fat, methyl donors and fibre, influence gene expression in the intestines ${ }^{(155,156)}$. The pig as a model for humans has a high potential value in this area of research, but comparative studies are limited ${ }^{(137,157-159)}$. For example, high-protein milk formula transiently altered ex vivo ileal permeability in piglets and increased responses to LPS challenge in young adults ${ }^{(157)}$. Neonatal dietary protein excess also led to long-term alterations in colonic barrier function under oxidant stress in female pigs ${ }^{(158)}$. Finally, alterations in 
mother-to-offspring transmission of GIT microbiota (for example, using antibiotics) had long-term consequences on IAP and iHSP along the GIT in pigs ${ }^{(137,159)}$

Intra-uterine growth retardation (IUGR) is a risk factor for the metabolic syndrome and obesity, possibly through low-grade inflammation ${ }^{(160,161)}$. For example, the prevalence of the metabolic syndrome was found to be 10-fold higher in human subjects weighing less than $3.0 \mathrm{~kg}$ at birth compared with those with more than $4.3 \mathrm{~kg}$ of birth weight ${ }^{(161)}$. IUGR in the pig occurs naturally for some pigs in litters ${ }^{(162)}$. IUGR piglets display immature gut, higher HSP70 both in utero and after birth, and altered pro-inflammatory NF-кB signalling pathway ${ }^{(163-165)}$. The IUGR piglets fed high-protein milk formula had higher ileal permeability and altered neuronal regulation of the gut barrier function later in life ${ }^{(166)}$. Finally, the GIT microbiota is an important modulator of gut development ${ }^{(156,167)}$

\section{Conclusion}

The available literature suggests that basic mechanisms of intestinal permeability and defence systems are conserved across species, including pigs and humans. Functional permeability studies ex vivo suggest the pig to be close to the human. However, data are scant for intestinal IAP and inducible HSP defence systems in humans, and only indirect evidence suggests some similarities and differences between pigs and humans. Data on pig nutrition and gut health are numerous $^{(168-170)}$, making this species valuable to human nutrition research, due to anthropometric, dietary and GIT anatomical and physiological similarities. Moreover, nutritional programming of intestinal gene expression and long-term effects on growth and health can be assessed in this out-bred species and should be relevant to humans.

\section{Host-microbiota interactions}

One of the main aspects in the study of GIT function is the microbial population. Animals are associated with a diverse microbial community, primarily consisting of symbiotic and commensal bacteria. Mammalian bacterial diversity has been related to phylogeny and claimed to be influenced by the host diet, increasing in meat eaters compared with non-meat eaters $^{(171)}$. The GIT microbiota of modern humans is that of omnivorous primates. Original studies of the GIT microbiota focused on their role in inflammatory diseases, with the view that bacteria were pathogens only. However, the importance of the microbiota has been revisited in the past decade. It is now widely accepted that the GIT microbiota play a crucial role in maintaining homeostasis. The complex and intimate relationship between GIT microbial communities and its host is becoming clearer, due, in part, to large-scale microbial genome-sequencing programs ${ }^{(172)}$. Metagenomic sequencing of total community DNA provides information about both the phylogenetic representation as well as functional genes. Interrogation of metagenomic information has revealed three distinct 'enterotypes' in the human microbiota that are identifiable by changes in the population of at least one of the three genera: Bacteroides, Prevotella and Ruminococcus ${ }^{(173)}$.
Enterotypes are not limited to humans, but also occur in mice $^{(174)}$ and pigs ${ }^{(175)}$. Advancement in sequencing total RNA (metatranscriptomics), identifying total proteins (metaproteomics) and total metabolites (metametabolomics) has added further knowledge on the GIT ecosystem complexity both in humans and in pigs ${ }^{(176,177)}$. The use of an ecosystems biology approach, in association with 'omics approaches, will lead to a more complete understanding of the complex interactions between the thousands of bacterial species in the GIT and the host ${ }^{(178)}$

The physiological similarity between humans and pigs in GIT development, digestive function, and gastrointestinal fermentation profiles (the colon being the main site of bacterial fermentation in pigs and humans) suggests that the pig is preferred over other non-primate models for digestive and metabolic disease studies relating to humans ${ }^{(16,179,180)}$. Moreover, the pig is a human-sized omnivorous species. The pig has been extensively used as a model for nutritional studies as its protein and lipid metabolism is comparable with humans ${ }^{(102)}$. Increased knowledge of the pig microbiota composition and structure along the intestinal compartments being similar to humans further supports the pig as an ideal biomedical model for humans ${ }^{(175,181)}$. This section outlines the similarities and differences of the pig and human in hostmicrobiota interactions.

\section{Similarities between pigs and humans in gut microbiota}

Dominant phyla. The largest microbiota of the body is located in the GIT and the set of gene products provides a diverse range of biochemical and metabolic activities to complement host physiology. Hundreds of species are present in the GIT lumen, only belonging to a few microbial phyla. Firmicutes and Bacteroidetes are the two dominant bacterial phyla in the human and mouse gut, with the Proteobacteria, Actinobacteria, Fusobacteria and Verrucomicrobia phyla as subdominant phyla $^{(171,182-184)}$. Similarly, the GIT microbiota in pigs, as well as in wild suidae, mainly consists of the Firmicutes and Bacteroidetes phyla ${ }^{(185,186)}$ (Table 3). Recently two different enterotype-like clusters, primarily distinguished by unclassified Ruminococcus and Prevotella, have been identified in pig faeces $^{(175)}$. Their phylogenetic composition was highly similar to two of the enteroptypes described in humans ${ }^{(173)}$. Interestingly, in pigs, as in humans, enterotype-like clustering distribution can vary within an individual over time ${ }^{(187)}$.

Postnatal and early life microbial colonisation. During the first few hours after birth (postnatal), contact with environmental and colonising bacteria is essential for healthy intestinal and immune maturation. The major role of microbiota in the development of the neonatal GIT was confirmed in conditions where colonisation was modified early in life through exposure to micro-organisms of maternal and environmental origins, through nutrients consumed and through antibiotic treatments. During infancy, the composition of the intestinal microbiota is unstable and more variable than in older children and adults. Diet-induced adaptation of the microbiota may vary from the proximal to the distal parts of the intestine. The composition 
Table 3. Mean values of the amount of total SCFA throughout life in pig and human faeces

\begin{tabular}{lcccccccccccccc}
\hline & \multicolumn{10}{c}{ Age in months } \\
\cline { 2 - 11 } & 0 & 1 & 1.1 & 1.6 & 2 & 3 & 6 & 6.4 & 7.5 & 9 & 12 & 18 & 24 & Adults \\
\hline $\begin{array}{l}\text { Humans } \\
\text { SCFA (mmol/kg faeces) }\end{array}$ & $6 *$ & 63 & - & - & - & 66 & 84 & - & - & 89 & 101 & 110 & 120 & 77 \\
$\begin{array}{l}\text { Pigs (mol/kg DM faeces) } \\
\text { SCFA(mmol/kg }\end{array}$ & - & $61 \dagger$ & $284 \dagger \ddagger$ & $383 \dagger$ & $225 \dagger$ & - & - & $51 \S$ & $72 \S$ & - & - & - & - & $50 \S$ \\
\hline
\end{tabular}

* SCFA content in meconium; values adapted from Midtvedt \& Midtvedt ${ }^{(414)}$

$\dagger$ Commercial pigs (Large White $\times$ Landrace $\times$ Pietrain breed) weaned $28 \mathrm{~d}$ of age, data expressed per kg of faecal DM (Montagne et al. ${ }^{(415)}$ ).

$\ddagger 5$ d post-weaning.

$\S$ Post-pubescent (6.4 and 7.5 months-old Large White $\times$ Landrace $\times$ Pietrain breed) and gestating sows (1.5-2 years-old Large White $\times$ Landrace breed), data expressed per kg of faecal fresh matter (I Le Huerou-Luron, unpublished results).

that is typically measured from faecal samples does not reflect the large bacterial diversity along the intestinal tract. Animal models, specifically cannulated pigs, are useful for obtaining a better understanding of the interactions between microbiota present in different niches of the intestine and physiology relevant to humans ${ }^{(188)}$. Studies with germ-free piglets clearly show that bacteria are essential for the growth and development of the digestive tract ${ }^{(189)}$. The comparison of gene expression profiles in enterocytes of germ-free compared with conventional piglets has brought insight on the impact of microbiota on the GIT function ${ }^{(189)}$. Bacterial colonisation induces the maturation and function of several components of the mucosal immune system and defence in order to prevent inflammatory responses that would compromise the barrier function $^{(189-191)}$. In humans, neonates compared with older individuals have a decreased innate defence, a low production of IgA and a defective interaction between dendritic cells, $\mathrm{T}$ lymphocytes and regulatory $\mathrm{T}$ cells ${ }^{(192)}$. Similarly, the mucosal immune system is essentially absent in the neonatal piglet, even though the systemic immune tissue is well developed ${ }^{(193)}$, and piglets begin to synthetise secretory IgA from the second week of age ${ }^{(194)}$. The balance between $\mathrm{T}$ lymphocytes helper 1 and helper 2 responses in human and pig neonates is skewed toward the helper 2 profile, resulting in a high susceptibility to intracellular pathogen infection ${ }^{(195,196)}$. The impaired protection of the neonate against infections may be partly attributed to a deficient secretion of interferon ${ }^{(195,197)}$.

It only takes a few hours for bacteria to appear in the faeces of mammalian neonates ${ }^{(198,199)}$. Facultative anaerobic bacteria, such as Proteobacteria, are the first colonisers. These bacteria reduce oxygen concentration in the GIT and allow strict anaerobes, such as members from the genus Bacteroides and the phyla Actinobacteria and Firmicutes, to colonise the intestine. During the first year of life in humans and the first 6 months in pigs, the intestinal microbiota composition fluctuates widely between individuals and over time, before resembling the adult status (Table 4). The potential use of piglets as a model for human studies is reinforced by the early colonisers, Bacteroides and Escherichia/Shigella being similar in humans. However, the substantial presence of Lactobacillus and Streptococcus in pigs is unparalleled in humans.

Early disturbances of the microbial colonisation process, such as induced by high-hygiene environments or by antibiotic treatment, have major consequences for the developmental sequence of the GIT microbiota and for host metabolism ${ }^{(200)}$. An advantage of the porcine model is the flexibility to compare different early environmental-rearing conditions, using, for example, outdoor and indoor sow-reared piglets or isolatorreared neonates. Mulder et al. ${ }^{(201)}$ showed large differences in composition of ileal-adherent microbiota between outdoor and indoor sow-reared animals, which corresponded to major differences in intestinal immune activation. Excessive hygiene appears to interfere with the normal processes of bacterial stabilisation and alters immune development. Mulder et $a l^{(202)}$ showed that the succession of events that lead to a stable adult microbiota depends on colonisation during the first $2 \mathrm{~d}$ of life, and also on continuous exposure to highly diverse microbiota during the early development at least up to weaning at 4 weeks of age. The use of antibiotics, in combination with stressors in early life, was shown to affect adult pig microbiota and intestinal gene expression, including genes involved in immunerelated processes ${ }^{(203)}$. This observation in pigs corroborates human studies indicating that changing the environmental conditions, and in particular microbial exposure, throughout early life affects the development of immune diseases ${ }^{(204)}$. Whether inducing early change in immune homeostasis by modifying microbiota would lead to different sensitivity of pigs to infectious or inflammatory challenge, such as recently reported with early spray-dried supplementation ${ }^{(205)}$, warrants further investigation.

Many beneficial strategies have been suggested to strengthen the postnatal development of presumably beneficial microbiota and GIT functions, including: changing the composition of maternal food during gestation and lactation; changing the composition of infant formulas; and favouring breast-feeding over formula-feeding during the suckling period ${ }^{(180,206)}$. For example, feeding neonatal piglets with formula supplemented with prebiotics increased the bacterial numbers by 5 -fold, the content of folic acid by $53 \%$ and growth of the colon ${ }^{(207)}$. Similarly, supplementation of the sow diet with prebiotics during gestation and lactation was associated with $50 \%$ greater fermentative activity of the caecal microbiota, accelerated development of the intestinal immunity, and improved intestinal protection by increasing ileal Peyer's patch production of secretory IgA in the offspring by $46 \%{ }^{(195)}$. Faecal secretory IgA also increased by $170 \%$ in healthy infants who receive a prebiotic-supplemented formula ${ }^{(208)}$. These results in pigs and humans underline the key role of maternal nutrition during 


\section{Pig models}

Yorkshire sows and $15 \mathrm{~d}$-old piglets $(n 7$ and 6$)$

Maternal diet with vegetable $v$. fish oil

Diet with supplements $(30 \mathrm{~g} / \mathrm{kg})$ of either soyabean oil or tuna oil

Gestation and lactation diet with lard or linseed oil

Conventional low-fat diet $(3 \%) v$. three high-fat diets $(6 \%)$ i.e high-fat saturated, high-fat oats (rich in

A), and high-fat linseed (rich in ALA)

Studies on maternal milk, formulas and FA

Mother's milk compared with formula containing SFA Male Yorkshire piglets (six as MCT oil or formula with MCT and fish oil

Maternal milk $v$. infant formula

Artificial feeding with sows' milk, control formula, or formula enriched with $n-3$ FA with low-EPA fish oil at high or low concentration, or formula enriched with $n-3$ and $n-6$ FA from either egg yolk- or pig rain-phospholipids

Pig milk formula devoid of DHA for 2 weeks, formula with DHA TAG ( $1 . .8 \%$ of total fat) for 2 weeks, control formula for 4 weeks, or control formula for 2 weeks followed by supplemented formula for 2 weeks

Four milk diets differing in their FA composition: deficient, contemporary, evolutionary, supplemented

Supplementation with $0.2 \%$ cholesterol, $0.2 \% \mathrm{DHA}$, or cholesterol plus DHA to the basal milk formula

Three diets containing ARA $(0.64 \%)$ and DHA $(0.34 \%)$, ARA being provided by three different sources

Liquid diets with varying concentrations of $\mathrm{Fe}$ : control, mildly deficient, severely deficient (i.e. 100 25 , or $10 \mathrm{mg} / \mathrm{kg}$ milk solids) emale $(n 12)$ and intact diet) and their piglets

Sows (Landrace $\times$ Large White) and their piglets (Landrace $\times$ Large White $\times$ Pietrain) $(n 20)$

Last $21 \mathrm{~d}$ of pregnancy

Last 3 months of gestation and lactation

From weaning of the previous litter until weaning of the experimental litter

From birth to $18 \mathrm{~d}$ per diet)

14- to 21-d-old piglets

Newborn piglets

36-h-old male large whit piglets ( $n$ 16)

Male Yorkshire piglets (six per diet)

Newborn piglets $(n 16)$

Piglets (eight per diet) selected from five sows (Yorkshire Landrace bre to Hampshire boars) male $(n 12)$ Yorkshire piglets

From birth to $30 \mathrm{~d}$
Exposure periods

Impacts on brain composition and development

Higher DHA levels (fish oil increased DHA and EPA milk levels)

Tuna oil increased the proportionate amount of total $n-3$ FA (especially DHA) but proportion of ARA was decreased; umbilical plasma cannot be used to predict the FA status of piglet brain

References

Arbuckle \&

Innis ${ }^{(416)}$

Rooke et al. ${ }^{(417)}$

No difference for $n$-6 PUFA; proportions of DPA and DHA were greater in the brain of linseed oil-fed piglets than in that of lard-fed piglets during the suckling period

de Quelen

Sampels et al. ${ }^{(419)}$

列 EPA, DPA and DHA in piglet brain

Piglets fed formula with fish oil had similar brain ARA and EPA but higher DHA than did piglets fed sows' milk; data from plasma and erythrocytes were not reliable predictors of differences in brain longchain PUFA

Higher deposition of DHA with formula - no difference for $20: 4 n-6$ and precursors - maternal milk and formula are not equivalent with precursors - maternal milk and formula are not equival
respect to precursor and bioavailability and processing

respect to precursor and bioavailability and processing
DHA levels in the brain correlated with plasma; $4.5 \%$ fish oil decreased ARA in th the brain correlated with plasma, $4.5 \%$ fish oil decreased ARA in the cortex and cerebellum whereas $1.5 \%$ limited this decline in the cerebellum, ARA level was 10-20\% higher in brain tempora lobe than in parietal, frontal and occipital lobes; egg phospholipid increase both DHA in the brain and ARA in the temporal lobe

DHA incorporated efficiently during both early and late supplementation periods; the piglet brain cortex is responsive to dietary DHA; higher rate of DHA synthesis in the piglet compared with the human infant

Contemporary diet high in LA compromises DHA accretion and leads to increased $n-6$ adrenic acid and DPA in the brain; evolutionary low in LA supports high brain DHA; DHA increased brain levels of DHA but not $n-3$ EPA and DPA; $n-6$ DPA is efficiently acylated and preferentially taken up over DHA in primary cultures of cortical neurons; DHA but not $n$-6 DPA supports growth of secondary neurites

Cholesterol reduced the brain levels of glutamate, serine, glutamine, threonin, $\beta$-alanine, alanine, methionine, isoleucine, leucine and $\gamma$ aminobutyrate but increased glycine and lysine; DHA similarly affected these amino acids and taurine; DHA reduced ammonia in affected these amino acids and taurine; DHA reduced ammonia in
plasma and brain plasma and brain ARA bioequivalent across treatments in the brain; DHA brain levels
unaffected by diet

Decreased Fe concentration in the hippocampus (but not in the prefrontal cortex) in deficient piglets compared with control; level of the transferrin receptor mRNA greater in the prefrontal cortex of control piglets (but not in the hippocampus); cognitive impairment in a hippocampal-dependent task in deficient piglets

(n)

Wall et al. ${ }^{(420)}$

Alessandri

Goustard-Langelie et al (422) 


\begin{tabular}{|c|c|c|c|c|}
\hline Nutritional treatments & Pig models & Exposure periods & Impacts on brain composition and development & References \\
\hline $\begin{array}{l}\text { Unsuckled control piglets }(n 7) \text {, suckled piglets with } \\
\text { sows for } 24 \text { or } 72 \mathrm{~h}(n 14) \text {, or experimentally fed } \\
\text { piglets given milk colostrum }(n 14) \text {, an elemental } \\
\text { diet }(n 14) \text {, or the elemental diet supplemented with } \\
\text { purified plasma Ig }(n 14)\end{array}$ & $\begin{array}{l}\text { Crossbred (Yorkshire } \times \\
\text { Swedish Landrace) } \times \\
\text { Hampshire piglets }(n 63)\end{array}$ & From birth to $24 \mathrm{~h}$ or $72 \mathrm{~h}$ & $\begin{array}{l}\text { Positive correlation between growth, level of total plasma protein and } \\
\text { IgG, and hippocampus development in sow-reared piglets; } \\
\text { decreased level of astrocyte-specific protein }\end{array}$ & $\begin{array}{l}\text { Pierzynowski } \\
\quad \text { et al. }{ }^{(428)}\end{array}$ \\
\hline \multicolumn{5}{|l|}{ Studies on solid diets and FA } \\
\hline $\begin{array}{l}\text { Diet containing partially hydrogenated fish oil, } \\
\text { partially hydrogenated soyabean oils, or lard }\end{array}$ & $\begin{array}{l}\text { Norwegian Landrace } \\
\text { 3-week-old female pigs }\end{array}$ & From 3 weeks to 2 years & $\begin{array}{l}\text { No trans-FA detected in brain phosphatidylethanolamine; increased } \\
\text { level of } n-6 \text { DPA with dietary trans-FA }\end{array}$ & $\begin{array}{l}\text { Pettersen \& } \\
\quad \text { Opstvedt }\end{array}$ \\
\hline $\begin{array}{l}\text { High-fat high-cholesterol diet } v \text {. low-fat low- } \\
\text { cholesterol diet }\end{array}$ & $\begin{array}{l}\text { Female pigs selected for } \\
\text { three generations for high- } \\
\text { serum and low-serum } \\
\text { cholesterol }(n 36)\end{array}$ & $92 \mathrm{~d}$ & No difference in the brain or other tissues, apart from the liver & Harris et al. ${ }^{(430)}$ \\
\hline High-PUFA diet $v$. low-PUFA diet & $\begin{array}{l}\text { Male Yorkshire piglets (six } \\
\text { per diet) }\end{array}$ & From birth to $30 \mathrm{~d}$ & $\begin{array}{l}\text { Frontal cortex phosphatidylcholine, phosphatidylserine, and } \\
\text { phosphatidylethanolamine were higher in piglets fed the low-PUFA } \\
\text { diet; fewer arm entries on the maze but no difference between } \\
\text { groups when given L-DOPA }\end{array}$ & $\mathrm{Ng} \& \operatorname{lnnis}(249)$ \\
\hline $\begin{array}{l}\text { Diet containing } 4 \% \text { fish oil or } 4 \% \text { high-oleic acid } \\
\text { sunflower-seed oil }\end{array}$ & 7-week-old piglets & 8 weeks & $\begin{array}{l}\text { Higher proportion of DHA in the frontal, parietal and occipital lobes but not in } \\
\text { the temporal lobe with fish oil - less DHA in temporal than in other lobes }\end{array}$ & $\begin{array}{l}\text { Dullemeijer } \\
\text { et al..(431) }\end{array}$ \\
\hline Diet with 0 v. $0.5 \%$ cholesterol & $\begin{array}{l}\text { Male }(n 18) \text { and female }(n \\
\text { 18) pigs genetically } \\
\text { selected for high (HC) or } \\
\text { low (LC) plasma total } \\
\text { cholesterol }\end{array}$ & $\begin{array}{l}\text { From weaning }(24-36 \mathrm{~h}) \text { to } \\
\quad 42 \mathrm{~d}\end{array}$ & $\begin{array}{l}\text { Brain weight greater in } \mathrm{HC} \text { than } \mathrm{LC} \text { pigs but not affected by sex or diet; } \\
\text { dietary cholesterol tended to increase brain cholesterol }\end{array}$ & Pond et al. ${ }^{(432)}$ \\
\hline $\begin{array}{l}\text { Four different diets with low }(3 \%) \text { or high }(25 \%) \text { fat, } \\
\text { with }(1 \%) \text { or without conjugated LA }\end{array}$ & $\begin{array}{l}\text { Newborn piglets ( } n 24 \text {; six } \\
\text { per group) }\end{array}$ & $16 d$ & $\begin{array}{l}\text { Significant decrease in } n-6 \text { long-chain PUFA biosynthesis by inhibition } \\
\text { of LA elongation and desaturation; inhibitory effect more } \\
\text { pronounced in pigs fed a low-fat diet (3\%) than a high-fat diet ( } 25 \%)\end{array}$ & Lin et al. ${ }^{(433)}$ \\
\hline Control v. high-fat diet & $\begin{array}{l}\text { 19-week-old Ossabaw } \\
\text { minipigs }\end{array}$ & $\begin{array}{l}\text { 19- to } 37 \text {-week-old with two } \\
\text { phases }\end{array}$ & $\begin{array}{l}\text { The high-fat diet influenced the lipid metabolome in the brain cortex; } \\
\text { not necessarily correlated with plasma and urine }\end{array}$ & $\begin{array}{l}\text { Hanhineva } \\
\text { et al. } .^{(434)}\end{array}$ \\
\hline $\begin{array}{l}\text { Dietary mono-conjugated ALA isomers compared } \\
\text { with conjugated ALA, non-conjugated } n-3 \text { PUFA and } \\
n-6 \text { PUFA }\end{array}$ & 3-week-old piglets ( $n$ 32) & $15 \mathrm{~d}$ & $\begin{array}{l}n-3 \text { PUFA composition decreased in the conjugated ALA compared } \\
\text { with } n-3 \text { PUFA group }\end{array}$ & $\begin{array}{l}\text { Castellano } \\
\quad \text { et al. }{ }^{(435)}\end{array}$ \\
\hline \multicolumn{5}{|l|}{ Other studies on solid diets or drinking water } \\
\hline $\begin{array}{l}\text { Water with sulfate in excess at } 2000 \mathrm{ppm} v \text {. } \\
1000 \mathrm{ppm}\end{array}$ & $\begin{array}{l}\text { Sample of two sows, six live } \\
\text { piglets, six dead piglets } \\
\text { from a herd of } 125 \text { gilts and } \\
\text { sows }\end{array}$ & & Myelin deficiency in spinal cord and brain of sows and piglets & Jericho et al. ${ }^{(436)}$ \\
\hline $\begin{array}{l}\text { Chloroquine intoxication via the diet in doses of } \\
2.0-3.5 \mathrm{~g} / \mathrm{kg} \text { food } v \text {. control diet }\end{array}$ & Göttingen minipig & $\begin{array}{l}\text { From } 100 \text { to } 240 \mathrm{~d} \text { and then } \\
\quad \text { from } 177 \text { to } 219 \mathrm{~d}\end{array}$ & $\begin{array}{l}12 \% \text { increase of ganglioside concentration in the cerebrum, with } \\
\text { allocortex much more affected than isocortex, but no alteration of } \\
\text { phospholipids or cholesterol in the brain }\end{array}$ & Klinghardt et al. ${ }^{(437)}$ \\
\hline Control, swainsonine ${ }^{*}$-fed and locoweed-fed animals & Pigs & & Alterations in the structure of brain glycoproteins & Tulsiani et al. ${ }^{(438)}$ \\
\hline $\begin{array}{l}\text { Diet containing } 1 \mathrm{mg} \text { Cd per } \mathrm{kg} \text { feed, as well as } 0,50 \text {, } \\
100 \text { or } 200 \mathrm{mg} \text { Cu per kg feed }\end{array}$ & $\begin{array}{l}\text { Male castrated weanling } \\
\text { crossbred pigs (Deutsche } \\
\text { Landrace } \times \text { Pietrain) }\end{array}$ & 3 months & $\mathrm{Cd}$ retention increased in correlation with $\mathrm{Cu}$ content of the feed & Rambeck et al. ${ }^{(439)}$ \\
\hline $\begin{array}{l}\text { Experiment } 1 \text { ( } n 16 \text { obese pigs): adequate diet }(21 \% \\
\text { protein, } 3 \% \text { fat) v. protein-deficient diet }(5 \% \\
\text { protein, } 23 \% \text { fat) for } 7 \text { or } 8 \text { weeks; experiment } 2(n \\
16 \text { genetically lean or obese pigs): adequate or } \\
\text { protein-deficient diet for } 10 \text { weeks }\end{array}$ & $\begin{array}{l}\text { 3-week-old genetically lean } \\
\text { or obese pigs }\end{array}$ & 7,8 or 10 weeks & $\begin{array}{l}\text { Experiment 1: reduced brain weight and cellularity after } 7 \text { weeks but } \\
\text { not } 8 \text { weeks or protein restriction; experiment 2: lean and obese pigs } \\
\text { responded similarly, with no interaction between diet and genotype } \\
\text { for brain weight }\end{array}$ & Pond et al. ${ }^{(440)}$ \\
\hline Diet containing $500 \mathrm{mg}$ quercetint $/ \mathrm{kg}$ body weight & $\begin{array}{l}\text { Cross-bred castrated male } \\
\text { pigs }(n 2 ; 122-138 \mathrm{~kg})\end{array}$ & $3 d$ & Low concentration in the brain compared with liver and kidney & De Boer et al. ${ }^{(441)}$ \\
\hline
\end{tabular}

FA, fatty acids; ARA, arachidonic acid; DPA, docosapentaenoic acid; LA, linoleic acid; ALA, a-linolenic acid; MCT, medium-chain TAG; L-DOPA, L-3,4-dihydroxyphenylalanine; HC, high cholesterol; LC, low cholesterol; ppm, parts per million. * Swainsonine is a plant toxin. 
pregnancy in supporting neonatal development of the GIT immune system via modulation of microbiota.

The health benefits of breast-feeding have been recognised for a long time. Breast-feeding is associated with earlier colonisation with bifidobacteria, partly in relation to the presence of oligosaccharides in human maternal milk ${ }^{(177)}$. As in humans, breast-fed piglets showed lower intestinal growth and permeability compared with high protein formula-fed ones ${ }^{(166,177)}$. One major issue in human studies on the effect of breast- $v$. formula-feeding on gut function is the great number of confounding factors which are difficult to circumvent, including quantification of food intake in breast-fed infants, variable length of exclusive breast-feeding, and variability of the composition of milk formulas. Animal models are used to help control these confounding factors, in particular, use of an automatic milk feeder that provides neonatal piglets with artificial milk as similar as possible to maternal milk ${ }^{(209)}$. These studies using a formula-fed piglet model provide strong support for the idea that short dietary changes before weaning associated with a modification of the early intestinal bacterial colonisation can have a long-term impact on the severity of inflammatory responses without changing the basal physiology of the intestinal barrier and cytokine profile in the intestine ${ }^{(157,158)}$. No similar data are available from human studies due to the invasive procedure required for intestine functionality research. However, breastfeeding is clearly associated with lower incidence of necrotising enterocolitis and diarrhoea in both human and pig neonates $^{(206,210)}$.

\section{Differences between pigs and humans in gut microbiota}

Dominant phyla. Differences in the most abundant genera exist between the human and the pig intestinal microbiota ${ }^{(180)}$. Belonging to the Bacteroidetes phylum, the most abundant genus is Bacteroides in humans, averaging 9 to $42 \%$ of total bacteria $^{(199)}$, while the most abundant genus is Prevotella in weaned pigs, accounting for more than $20 \%$ of total bacteria $^{(175,211)}$. In adult humans, the phylum Actinobacteria may represent up to $15 \%$ of total bacteria. It comprises bifidobacteria, the most predominant group detected in infants ( $40 \%$ in average in faecal samples of 6-week-old European infants) ${ }^{(212)}$. The population of bifidobacteria present in the intestine of pigs is considerably lower, with less than $0.1 \%$ of total sequences in the faecal samples of 22-week-old commercial pigs ${ }^{(211)}$. Dietary, environmental and behavioural (such as feeding habits) factors contribute to the speciesspecificity of the composition of microbiota.

Epigenetic mechanisms. The concept that early developmental dietary insults (poor or inadequate pre- or postnatal nutrition, for example) can have long-term consequences on health later in life has been termed developmental programming, or 'developmental origins of health and disease'. The GIT microbiota appears to have an important role in the GIT programming as its initial composition creates distinct individuality during the lifespan ${ }^{(167,213,214)}$. A mechanism leading to these long-term effects may be due to epigenetically active fermentation metabolites such as in histone acetylation ${ }^{(215,216)}$. However, no studies on epigenetic modifications underlying long-term effects on early microbial colonisation and gut function are available in pigs. Despite limited studies, use of the pig as a model for humans to assess the effects of early nutrition on the development of microbiota is gaining acceptance amongst the scientific community.

\section{Conclusion}

Although similarities exist between humans and pigs in terms of dynamics of postnatal maturation of microbiota diversity and structure, responses to environmental factors, including dietary factors, and phyla composition, differences in the most abundant genera exist. As reviewed by Heinritz et al. ${ }^{(180)}$, understanding the crucial role and complexity of human microbiota could be improved by the use of human flora associations in pigs. This model has been successfully established taking advantage of the higher similarity between pigs and humans compared with the widely studied rodent models. In addition to the similarities in anatomy, physiology and metabolism between the pig and humans, the pig is more similar to humans than rodents with increased Bacteroides spp. and bifidibacteria $^{(217,218)}$. The pig has already successfully been used as a model for humans to study nutritional interventions ${ }^{(219,220)}$. In addition, the human flora-associated pig can be considered as a useful model for human infants. However, stability of the implanted human microbiota in the gut of pigs during the lifespan remains to be investigated in studies regarding developmental programming.

The relationship between nutrition and the brain in the pig Current outline on research in nutrition and neurosciences in pigs

Nutrient intake is driven by homeostatic and hedonic signals of peripheral, gastrointestinal, endocrinological and metabolic origin that convey in the central nervous system where they are integrated in a cognitive process referred to as the hungersatiety cycle. Dietary nutrients also have an impact on brain development and function. Neuroscientific studies in pigs have progressed in recent years, partially to address scientific matters that cannot be studied in humans for ethical reasons.

This section summarises the pig studies, mostly in vivo and the minimally invasive neurocognitive explorations that are paralleled in human studies. Second, we will summarise the pig studies, mostly post-mortem explorations on brain tissues, which present differences or no equivalent in humans.

\section{Similarities between pigs and humans in terms of brain functions}

Brain responses to food signals. Describing brain responses to food signals is important to investigate food pleasure and motivation, or to decipher the brain networks underlying sensory and nutrient perception. An extensive literature is available on this topic in the human, describing mostly via functional MRI the brain responses to various food signals, according to different internal states (for example, hungry $v$. sated) or conditions (for example, lean $v$. obese), and many review papers 
are available on this topic (for example, Rolls ${ }^{(221)}$; Stice et $a l .{ }^{(222)}$; Carnell et $\left.a l .{ }^{(223)}\right)$. Studies using large animal models have not yet completely made use of the opportunities provided by in vivo brain imaging. The very first studies using functional imaging to describe food-induced brain responses in pigs used ${ }^{99 \mathrm{~m}} \mathrm{Tc}-\mathrm{HMPAO}$ (technetium hexamethylpropyleneamine oxime) SPECT (single photon emission computed tomography) and $\left[{ }^{18} \mathrm{~F}\right]$ fluorodeoxyglucose positron emission tomography to map cerebral blood flow ${ }^{(224-226)}$ and brain GLU metabolism $^{(227)}$, respectively. These studies addressed the use of the pig to study food conditioning, looking at specific modulations of the response of the brain reward circuit after exposure to flavours with positive or negative hedonic values $^{(226,227)}$. These studies provide two major outcomes: (1) functional imaging in anaesthetised pigs can be implemented to explore brain responses to different food signals, as in humans; and (2) the brain circuits activated by the perception of food signals are similar to those described in the human (for example, frontostriatal areas, amygdala and insular cortex). Boubaker et al. ${ }^{(22)}$ showed in pigs that duodenal and portal GLU infusions led to different systemic and brain responses in areas regulating food intake and pleasure. Clouard et al. ${ }^{(225)}$ compared congruent $v$. dissociated oral and duodenal SUC perception, and found different brain responses in the limbic and reward circuits. Studies in human subjects showed that brain responses to energy-providing sugars and sweeteners are not the same in the reward circuit (for reviews, see Low et $a .^{(228)}$ and Ochoa et $\left.a l .{ }^{(229)}\right)$, which resembles the results obtained by Clouard et $a l .^{(225)}$ in pigs. These studies are important to understand how the human brain correlates sugar cravings, as well as the neurobehavioural changes that could emerge due to the chronic consumption of, for example; sugars or non-energy sweeteners.

Impact of diet on brain activity, neurotransmission and cognition. Minipigs have become a widely accepted model for studying obesity and the metabolic syndrome ${ }^{(230-234)}$. They can be used to investigate the obesity-induced central modifications in humans, including decreased activity of the prefrontal cortex ${ }^{(235-237)}$ and altered dopaminergic function ${ }^{(237,238)}$. Val-Laillet et al. ${ }^{(239)}$ demonstrated in the Göttingen minipig that brain alterations similar to those described in obese humans exist in this model and that they are an acquired feature of obesity correlated to weight gain. In Pitman-Moore minipigs, Val-Laillet $e a{ }^{(240)}$ also described the effects of three high-lipid diets differing in their lipid sources and found that the basal GLU metabolism of the anterior prefrontal cortex and nucleus accumbens was highest with a diet enriched with sunflowerseed oil, intermediary with a diet enriched with lard, and lowest with a diet enriched with fish oil. These results demonstrate that specific dietary nutrients can modify brain metabolism independently from body weight, and that specific nutrients in excess might favour the onset of brain metabolism anomalies.

In humans, cognitive test scores were positively related to breast milk DHA and negatively related to linoleic acid, suggesting that high levels of dietary linoleic acid may impair cognition ${ }^{(241)}$.
Individual consumption of dietary FA had an impact on cognitive measures in children ${ }^{(242)}$, with $n-3$ FA being positively related to cognitive test scores in male and female children, while $n-6$ showed the reverse relationship. Higher scores in tests of neurodevelopment were found in infants fed formula with DHA than in infants fed formulas without DHA ${ }^{(243)}$. DHA supplementation in young boys increased the prefrontal cortex activation during sustained attention ${ }^{(24)}$. These results are consistent with the hypothesis that dietary DHA is assimilated by the brain and has a positive influence on cognition. Autopsy data show lower DHA in brain of human infants fed formula rather than those who were breast-fed ${ }^{(245,246)}$, which resembles the results obtained in pigs (Table 4).

In pigs, dietary FA significantly made an impact on the frontal cortex and striatum concentrations of neurotransmitters (for example, dopamine, serotonin) ${ }^{(247,248)}$. Another study showed fewer arm-entries in a maze in pigs receiving a low-PUFA diet compared with a high-PUFA diet, with the effect being probably dependent on central dopamine metabolism ${ }^{(249)}$. Epidemiological and clinical studies also suggest a relationship between dietary FA and altered functions of the nervous system, including neurocognitive disorders ${ }^{(250)}$. Dietary $n$-3 FA could also protect against brain disorders on neurotransmission, neuroprotection and neurogenesis ${ }^{(251)}$. However, data are lacking for pigs providing an opportunity to investigate the relationship between diet, brain activity and cognitive functions relevant to humans via in vivo imaging.

Peripheral neuromodulation to regulate eating behaviour in pigs. Vagal nerve stimulation (VNS) is a therapy for refractory epilepsy and psychiatric disorders ${ }^{(252,253)}$, but it has also received attention as a way to modulate food intake. Animal models, including pigs, were used to investigate this question $^{(254)}$. Diaz-Guemes et al. ${ }^{(255)}$ found that VNS increased central nervous activity, but no effect was observed on feeding behaviour. In contrast, other authors demonstrated a decreased weight gain, decreased fat gain and plasma insulin-like growth factor $\mathrm{I}^{(256)}$, or decreased food intake and specific activations in several brain areas associated with altered gastric myoelectric $\operatorname{activity}^{(257)}$ in growing pigs ${ }^{(258)}$. Another on-going study ${ }^{(259)}$ showed VNS-induced metabolism differences in the brain reward circuit only $7 \mathrm{~d}$ after VNS onset, meaning that quick central neuroplasticity phenomena can be induced by VNS, possibly modulating homeostatic and cognitive processes. In Göttingen minipigs fed a Western diet, VNS prevented further weight gain, decreased food intake and sweet cravings ${ }^{(254)}$, proving the therapeutic potential of this strategy. Similarly, some studies assessing the impact of VNS on eating behaviours and weight in individuals with other psychiatric and neurological disorders showed significant modulation of food cravings and body weight ${ }^{(260,261)}$, but there are significant discrepancies between studies. Overall, functional imaging in pigs has the potential to help validate and optimise therapies before their application to human patients.

Central neuromodulation to regulate eating behaviour in pigs. Recent development suggests that the deep-brain stimulation (DBS), a procedure for the treatment of Parkinson's or 
depression, might also be used to combat obesity ${ }^{(262-265)}$. The minipig has emerged as an ideal model for basic and preclinical studies on $\mathrm{DBS}^{(266)}$. Hypothalamic DBS was validated in the Göttingen minipig ${ }^{(267,268)}$ and resulted in reduced weight gain $^{(269)}$, as well as in behavioural and physiological changes that could be related to the activation of limbic and autonomic brain networks ${ }^{(270)}$. These results with pigs are similar to those described in human studies (for reviewes, see McClelland et $a l .{ }^{(260)}$ and Val-Laillet et $\left.a l .{ }^{(261)}\right)$. Shon et al. ${ }^{(271)}$ showed that DBS of the subthalamic nuclei in pigs can stimulate striatal dopamine release, which is related to food motivation and obesity $^{(272,273)}$, whereas Sauleau et al. ${ }^{(12)}$ managed to modify food motivation and learning. Knight et al. ${ }^{(274)}$ demonstrated that DBS of the nucleus accumbens, a putative target to combat obesity ${ }^{(262)}$, modulated the activity of the prefrontal, cingulate and insular cortices, which are brain regions involved in eating behaviour. A similarly low metabolic activity of the prefrontal cortex was observed in obese humans ${ }^{(235-237)}$ and minipigs ${ }^{(239)}$, an anomaly that was normalised via DBS of the cortex. The combination of DBS and MRI has been explored in pigs, in terms of image-guided brain navigation ${ }^{(275)}$, network activation $^{(274,276)}$ and safety ${ }^{(277-279)}$. These studies show the (mini) pig is a convenient model to study the impact of DBS on eating behaviour and nutritional diseases, and to test medical innovations in preclinical trials before being safely applied to humans.

New imaging approaches in pigs. In addition to the aforementioned neuromodulation studies, there are many innovative methods related to nutrition and brain activity used in humans that could potentially be investigated in pigs. Alstrup \& Smith $^{(280)}$ reviewed 10 years of positron emission tomography findings on neuromolecular processes in the living porcine brain and listed all the validated brain radio ligands including several molecules of interest for nutrition studies. Other methods can be used for molecular imaging in pigs, such as the wireless instantaneous neurotransmitter concentration system which allows the measure of neurotransmitter release in specific brain areas ${ }^{(281,282)}$. The non-invasive magnetoencephalography and electrocorticography ${ }^{(283)}$, as well as the functional near-IR spectroscopy and cortical imaging have been successfully implemented in the pig model ${ }^{(284)}$ and could be applied in the future to map brain responses to food and nutrient stimulations.

\section{Differences between pigs and humans, or pig studies with no equivalent in humans}

The most important corpus of literature investigating the impact of nutrition on the pig brain has been focused on brain composition and development, and especially on the role of dietary FA. The health consequences of dietary deficits or supplements of $n-3$ and $n-6$ FA are still controversial areas of human nutrition due to conflicting results. However, animal models such as the pig have the potential to bring new insight through bettercontrolled experimental designs ${ }^{(285,286)}$. Table 4 provides a comprehensive summary of this literature. Most of these results have no equivalent in human studies (other than exceptional post-mortem case studies), because it is not possible to assess, non-invasively, human brain composition or the administration of specific toxicants.

The BBB is important for the regulation of food intake and the blood-to-brain transport of dietary compounds ${ }^{(287)}$. The passage of xenobiotics ${ }^{(288)}$ or bismuth $^{(289)}$ into the brain has been investigated in pigs via post-mortem tissue analyses. However, the emergence of in vitro models of pig BBB ${ }^{(290-293)}$ have significant advantages for investigating the transport mechanisms of compounds into the brain. BBB transport of glutamate $^{(294)}$, alkaloids ${ }^{(295)}$, mycotoxins ${ }^{(296)}$ and central nervous system-active drugs ${ }^{(297)}$ was assessed with this model, which might help to understand the neural toxicology of dietary compounds and the effectiveness of medicines. An in vivo imaging study in obese minipigs showed increased BBB permeability with a diet enriched with fish oil characterised by an excessive amount of $n-3 \mathrm{FA}^{(240)}$. Transport of nutrients and their impact on the BBB integrity should receive more attention in the future to understand how the gut-brain axis is altered by nutritional diseases ${ }^{(298)}$, and to provide nutritional recommendations in humans. If the increased BBB permeability induced by high doses of $n$ - 3 FA is confirmed in humans, this could also have unexpected beneficial outcomes, for example to improve drug delivery to the brain in Alzheimer's disease ${ }^{(299)}$ or other neuropsychiatric disorders.

In pigs, central concentration of serotonin can modulate operant food intake behaviour ${ }^{(85)}$. In addition, brain DHA, which depends on dietary DHA, promotes central dopamine metabolism ${ }^{(249)}$. Dietary AA can also affect brain neurotransmitters in the hypothalamus ${ }^{(300-303)}$, suggesting that dietary manipulation of AA precursors of neurotransmitters may offer a practical means of reducing stress responses. Further studies are needed to verify whether these results may be of benefit in human nutrition, for example to help patients with stress disorders. Elmquist et al. ${ }^{(304)}$ suggested that central CCK increases with time in piglets in parallel to the ability to assimilate nutrients from a solid diet. Kenk et al. ${ }^{(305)}$ demonstrated via positron emission tomography imaging of cAMP, a strong region-specific signal in the brain, as well as an impaired cAMP-mediated signalling in obese pigs, giving some insight into pathological progression with potential for directing therapy in humans. Mycotoxin $^{(306,307)}$ and feed additives ${ }^{(308)}$ were also found to alter behaviour, neurotransmitter activity and metabolism in pigs. The decreased feed intake and increased aggressive behaviour observed in subjects contaminated with mycotoxins might be related to anomalies in brain monoamines, including dopamine and serotonin. Gbore ${ }^{(309)}$ demonstrated that the acetylcholinesterase activity in the hypophyses, hypothalamus and amygdala decreased with increased mycotoxin concentrations in the diet. These results are important to identify the risk associated with mycotoxin contamination and possible therapeutic interventions in humans.

Pig studies exploring the brain responses to specific diets relying on post-mortem methods have no equivalent human data. Kanitz et al $^{(310)}$ showed that low protein:carbohydrate dietary ratio during gestation may alter the brain expression of genes encoding key determinants of glucocorticoid activity in the fetus, with potential long-lasting consequences for stress 
adaptation and health. Also, increased c-Fos (a transcription factor) immunoreactivity in several brain structures was described after oral administration of fungi extracts in pigs ${ }^{(311)}$. Madsen et $a l .^{(312)}$ found that expression of the fat mass and obesity associated gene (FTO) transcript was detected at high levels in brain tissues and that these levels varied through the development and between specific brain areas. These results demonstrate a relationship between the genetic propensity to develop obesity and dietary habits at the cerebral level. Since the FTO gene has recently been associated with increased BMI in several human populations, the pig model might be used to investigate the epigenetic mechanisms that could lead to obesity-related brain anomalies in humans.

\section{Conclusions on the relationship between nutrition and the brain}

The general comparison between the brain of pigs and humans (Table 1) shows that, even if there are some differences in terms of size and structure, the overall brain anatomy and development in pigs are similar to those of humans. In addition, similar functional neuroimaging approaches have been transferred from humans to pigs. Understandably, many pig studies do not have any equivalent in humans (especially the invasive and terminal experiments). However, most of the in vivo functional brain explorations and therapies described in pig models are echoed in human studies, which highlight the fantastic potential of pig models for translational research in nutrition and neurosciences. In addition, the pig model is of high value to perform mechanistic, toxicological and epigenetics studies that could not be performed in humans for practical and ethical reasons.

\section{Acknowledgements}

The authors would like to thank Dr John L. Black and Dr Anton Pluschke for reviewing the manuscript and for their sound comments.

There are no conflicts of interest.

\section{References}

1. Baker DH (2008) Animal models in nutrition research. J Nutr 138, 391-396.

2. Gandarillas M \& Bas F (2009) The domestic pig (Sus scrofa domestica) as a model for evaluating nutritional and metabolic consequences of bariatric surgery practiced on morbid obese humans. Cienc Investig Agrar 36, 163-176.

3. Clouard C, Meunier-Salaun MC \& Val-Laillet D (2012) Food preferences and aversions in human health and nutrition: how can pigs help the biomedical research? Animal 6, $118-136$.

4. Roura E, Humphrey B, Klasing K, et al. (2011) Is the pig a good umami sensing model for humans? A comparative taste receptor study. Flavour Frag J 26, 282-285.

5. Spurlock ME \& Gabler NK (2008) The development of porcine models of obesity and the metabolic syndrome. J Nutr 138, 397-402.

6. Verma N, Rettenmeier AW \& Schmitz-Spanke S (2011) Recent advances in the use of Sus scrofa (pig) as a model system for proteomic studies. Proteomics 11, 776-793.
7. Bendixen E, Danielsen M, Larsen K, et al. (2010) Advances in porcine genomics and proteomics - a toolbox for developing the pig as a model organism for molecular biomedical research. Brief Funct Genomics 9, 208-219.

8. Stephen RM, Correa-Matos NJ, Donovan SM, et al. (2004) The effect of fermentable fibers on intestinal function and structure following Salmonella typhimurium infection. Gastroenterology 126, A517-A517.

9. Labib S, Erb A, Kraus M, et al. (2004) The pig caecum model: a suitable tool to study the intestinal metabolism of flavonoids. Mol Nutr Food Res 48, 326-332.

10. Mickelson BD, Greer FR \& Benevenga NJ (2005) The contribution of body protein to the supply of energy in starved newborn piglets is not preferentially suppressed by intravenous provision of glucose and fat. J Nutr 135, 2609-2615.

11. Nielsen KL, Hartvigsen ML, Hedemann MS, et al. (2014) Similar metabolic responses in pigs and humans to breads with different contents and compositions of dietary fibers: a metabolomics study. Am J Clin Nutr 99, 941-949.

12. Sauleau P, Lapouble E, Val-Laillet D, et al. (2009) The pig model in brain imaging and neurosurgery. Animal 3, 1138-1151.

13. McClain S \& Bannon GA (2006) Animal models of food allergy: opportunities and barriers. Curr Allergy Asthma Rep 6, 141-144.

14. Casani L, Segales E, Vilahur G, et al. (2004) Moderate daily intake of red wine inhibits mural thrombosis and monocyte tissue factor expression in an experimental porcine model. Circulation 110, 460-465.

15. Kubotsu SL, Hu J, Carnahan KG, et al. (2003) The effects of chronic ethanol consumption during early pregnancy on conceptus health and uterine function in pigs. Alcohol Clin Exp Res 27, 712-719.

16. Guilloteau P, Zabielski R, Hammon HM, et al. (2010) Nutritional programming of gastrointestinal tract development. Is the pig a good model for man? Nutr Res Rev $\mathbf{2 3}$, 4-22.

17. Lunney JK (2007) Advances in swine biomedical model genomics. Int J Biol Sci 3, 179-184.

18. Li D \& Zhang J (2013) Diet shapes the evolution of the vertebrate bitter taste receptor gene repertoire. Mol Biol Evol 31, 303-309.

19. Gilad Y, Przeworski M \& Lancet D (2007) Loss of olfactory receptor genes coincides with the acquisition of full trichromatic vision in primates. PLoS Biol 5, e148.

20. Groenen MA, Archibald AL, Uenishi H, et al. (2012) Analyses of pig genomes provide insight into porcine demography and evolution. Nature 491, 393-398.

21. Oostindjer $\mathrm{M}$, Bolhuis $\mathrm{JE}$, van den Brand $\mathrm{H}$, et al. (2010) Prenatal flavor exposure affects growth, health and behavior of newly weaned piglets. Physiol Behav 99, 579-586.

22. Bolhuis JE, Oostindjer M, Van den Brand H, et al. (2009) Voluntary feed intake in piglets: potential impact of early experience with flavours derived from maternal diet. In Voluntary Feed Intake in Pigs, pp. 37-52 [D Torrallardona and E Roura, editors]. Wageningen: Wageningen Academic Publishers.

23. Oostindjer M, Bolhuis JE, Simon K, et al. (2011) Perinatal flavour learning and adaptation to being weaned: all the pig needs is smell. PLoS One 6, e25318.

24. Langendijk P, Bolhuis JE \& Laurenssen BFA (2007) Effects of pre- and postnatal exposure to garlic and aniseed flavour on pre- and postweaning feed intake in pigs. Livest Sci $\mathbf{1 0 8}$, 284-287. 
25. Bachmanov AA \& Beauchamp GK (2007) Taste receptor genes. Annu Rev Nutr 27, 389-414.

26. Wellendorph P, Johansen LD \& Bräuner-Osborne H (2010) The emerging role of promiscuous 7TM receptors as chemosensors for food intake. In Vitamins and Hormones, pp. 151-184 [L Gerald, editor]. London: Academic Press.

27. Matsuo R (2000) Role of saliva in the maintenance of taste sensitivity. Crit Rev Oral Biol Med 11, 216-229.

28. Barretto RPJ, Gillis-Smith S, Chandrashekar J, et al. (2015) The neural representation of taste quality at the periphery. Nature 517, 373-376.

29. Foster SR, Blank K, See Hoe LE, et al. (2014) Bitter taste receptor agonists elicit G-protein-dependent negative inotropy in the murine heart. FASEB J 28, 4497-4508.

30. Foster SR, Roura E \& Thomas WG (2014) Extrasensory perception: odorant and taste receptors beyond the nose and mouth. Pharmacol Ther 142, 41-61.

31. da Silva EC, de Jager N, Burgos-Paz W, et al. (2014) Characterization of the porcine nutrient and taste receptor gene repertoire in domestic and wild populations across the globe. BMC Genomics 15, 1057.

32. Feng P \& Zhao H (2013) Complex evolutionary history of the vertebrate sweet/umami taste receptor genes. Chin Sci Bull 58, 2198-2204

33. Herrero-Medrano JM, Megens HJ, Groenen MA, et al. (2014) Whole-genome sequence analysis reveals differences in population management and selection of European low-input pig breeds. BMC Genomics 15, 601.

34. Kiuchi S, Yamada T, Kiyokawa N, et al. (2006) Genomic structure of swine taste receptor family 1 member 3, TAS1R3, and its expression in tissues. Cytogenet Genome Res $\mathbf{1 1 5}$ 51-61.

35. Humphrey B, Tedó G, Klasing KC, et al. (2009) Characterization of Porcine Umami Taste Receptors (pT1r1 and pT1r3). 41èmes Journées de la Recherche Porcine; Paris, France, pp. 165-166.

36. Moran AW, Al-Rammahi MA, Arora DK, et al. (2010) Expression of $\mathrm{Na}^{+} /$glucose co-transporter 1 (SGLT1) in the intestine of piglets weaned to different concentrations of dietary carbohydrate. Br J Nutr 104, 647-655.

37. Widmayer P, Breer H \& Hass N (2011) Candidate chemosensory cells in the porcine stomach. Histochem Cell Biol 136, 37-45.

38. Zhang J, Yin YL, Shu XG, et al. (2013) Oral administration of MSG increases expression of glutamate receptors and transporters in the gastrointestinal tract of young piglets. Amino Acids 45, 1169-1177.

39. Haid DC, Jordan-Biegger C, Widmayer P, et al. (2012) Receptors responsive to protein breakdown products in G-cells and D-cells of mouse, swine and human. Front Physiol 3, 65.

40. Colombo M, Trevisi P, Gandolfi G, et al. (2012) Assessment of the presence of chemosensing receptors based on bitter and fat taste in the gastrointestinal tract of young pig. J Anim Sci 90 , Suppl. 4, 128-130

41. Chamorro CA, de Paz P, Fernandez JG, et al. (1993) Fungiform papillae of the pig and the wild boar analyzed by scanning electron microscopy. Scanning Microsc 7, 313-322.

42. Roura E, Humphrey B, Tedo G, et al. (2008) Unfolding the codes of short-term feed appetence in farm and companion animals. A comparative oronasal nutrient sensing biology review. Can J Anim Sci 88, 535-558.

43. Miller IJ Jr \& Reedy FE Jr (1990) Variations in human taste bud density and taste intensity perception. Physiol Behav 47, 1213-1219.
44. Roura E, Baldwin MW \& Klasing KC (2013) The avian taste system: potential implications in poultry nutrition. Anim Feed Sci Technol 180, 1-9.

45. Lewis CJ, Catron DV, Combs GE, et al. (1955) Sugar in pig starters. J Anim Sci 14, 1103-1115.

46. Salmon-Legagneur E \& Fevrier R (1956) Feed preferences in young pigs. 2. Sugar in rations for young pigs. Ann Zootech 5, 73-79.

47. Kennedy JM \& Baldwin BA (1972) Taste preferences in pigs for nutritive and non-nutritive sweet solutions. Anim Behav 20, 706-718.

48. Glaser D, Wanner M, Tinti JM, et al. (2000) Gustatory responses of pigs to various natural and artificial compounds known to be sweet in man. Food Chem 68, 375-385.

49. Roura E, Shrestha B \& Diffey S (2013) Preference thresholds and sensory-motivated intake for four high intensity sweeteners in piglets. In Manipulating Pig Production XIV: Proceedings of the 14th Biennial Conference of the Australasian Pig Science Association. Melbourne, Australia; 24-27 November 2013, p. 44. Werribee, VIC: Australasian Pig Science Association (Inc.).

50. Galindo-Cuspinera V, Winnig M, Bufe B, et al. (2006) A TAS1R receptor-based explanation of sweet 'water-taste'. Nature 441, 354-357.

51. Tinti JM, Glaser D, Wanner M, et al. (2000) Comparison of gustatory responses to amino acids in pigs and in humans. Lebensm Wiss Technol 33, 578-583.

52. Guzmán-Pino SA, Sola-Oriol D, Figueroa J, et al. (2012) Dietary energy density affects the preference for protein or carbohydrate solutions and piglet performance after weaning. J Anim Sci 90, Suppl. 4, 71-73.

53. Guzmán-Pino SA, Solà-Oriol D, Figueroa $\mathrm{J}$, et al. (2014) Influence of the protein status of piglets on their ability to select and prefer protein sources. Physiol Behav 129, 43-49.

54. Tedo G, Roura E, Reina M, et al. (2010) Well-fed piglets prefer amino acids that elicit umami taste. J Anim Sci 88, e. suppl. 2, 211.

55. Danilova V, Hellekant G, Jean-Marie T, et al. (1998) Gustatory responses of the hamster Mesocricetus auratus to various compounds considered sweet by humans. J Neurophysiol 80, 2102-2112.

56. Danilova V, Roberts T \& Hellekant G (1999) Responses of single taste fibers and whole chorda tympani and glossopharyngeal nerve in the domestic pig. Sus scrofa. Chem Senses 24, 301-316.

57. Nelson SL \& Sanregret JD (1997) Response of pigs to bittertasting compounds. Chem Senses 22, 129-132.

58. Li X, Staszewski L, Xu H, et al. (2002) Human receptors for sweet and umami taste. Proc Natl Acad Sci U S A 99, 4692-4696.

59. Meyerhof W, Batram C, Kuhn C, et al. (2010) The molecular receptive ranges of human TAS2R bitter taste receptors. Chem Senses 35, 157-170.

60. Kosiol C, Vinar T, da Fonseca RR, et al. (2008) Patterns of positive selection in six mammalian genomes. PLoS Genet $\mathbf{4}$, e1000144.

61. Campbell MC, Ranciaro A, Zinshteyn D, et al. (2014) Origin and differential selection of allelic variation at tas2r16 associated with salicin bitter taste sensitivity in Africa. $\mathrm{Mol}$ Biol Evol 31, 288-302.

62. Roura E (2011) Taste beyond taste. In Manipulating Pig Production XIII: Proceedings of the 13th Biennial Conference of the Australasian Pig Science Association. Adelaide, Australia; 27-30 November 2011, pp. 106-117. Werribee, VIC: Australasian Pig Science Association (Inc.). 
63. Maljaars PW, Symersky T, Kee BC, et al. (2008) Effect of ileal fat perfusion on satiety and hormone release in healthy volunteers. Int J Obes 32, 1633-1639.

64. Ritter RC (2004) Gastrointestinal mechanisms of satiation for food. Physiol Behav 81, 249-273.

65. Barretero-Hernandez R, Galyean ML \& Vizcarra JA (2010) The effect of feed restriction on plasma ghrelin, growth hormone, insulin, and glucose tolerance in pigs. Prof Anim Sci 26, 26-34.

66. Zhang Y, Ning G, Handelsman Y, et al. (2010) Gut hormones and the brain. J Diabetes 2, 138-145.

67. Cummings DE \& Overduin J (2007) Gastrointestinal regulation of food intake. J Clin Invest 117, 13-23.

68. Perry B \& Wang Y (2012) Appetite regulation and weight control: the role of gut hormones. Nutr Diabetes $\mathbf{2}$, e26.

69. Geraedts MC, Troost FJ, Tinnemans R, et al. (2010) Release of satiety hormones in response to specific dietary proteins is different between human and murine small intestinal mucosa. Ann Nutr Metab 56, 308-313.

70. Larsen PJ, Fledelius C, Knudsen LB, et al. (2001) Systemic administration of the long-acting GLP-1 derivative NN2211 induces lasting and reversible weight loss in both normal and obese rats. Diabetes 50, 2530-2539.

71. Corring T \& Chayvialle JA (1987) Diet composition and the plasma levels of some peptides regulating pancreatic secretion in the pig. Reprod Nutr Dev 27, 967-977.

72. Clutter AC, Jiang R, McCann JP, et al. (1998) Plasma cholecystokinin-8 in pigs with divergent genetic potential for feed intake and growth. Domest Anim Endocrinol 15, 9-21.

73. Ripken D, van der Wielen N, van der Meulen J, et al. (2015) Cholecystokinin regulates satiation independently of the abdominal vagal nerve in a pig model of total subdiaphragmatic vagotomy. Physiol Behav 139, 167-176.

74. Jakob S, Mosenthin R, Zabielski R, et al. (2000) Fats infused intraduodenally affect the postprandial secretion of the exocrine pancreas and the plasma concentration of cholecystokinin but not of peptide $\mathrm{YY}$ in growing pigs. $J$ Nutr 130, 2450-2455.

75. Liddle RA, Goldfine ID, Rosen MS, et al. (1985) Cholecystokinin bioactivity in human plasma. Molecular forms, responses to feeding, and relationship to gallbladder contraction. J Clin Invest 75, 1144-1152.

76. Feinle C, Grundy D, Otto B, et al. (2000) Relationship between increasing duodenal lipid doses, gastric perception, and plasma hormone levels in humans. Am J Physiol Regul Integr Comp Physiol 278, R1217-R1223.

77. Seimon RV, Feltrin KL, Meyer JH, et al. (2009) Effects of varying combinations of intraduodenal lipid and carbohydrate on antropyloroduodenal motility, hormone release, and appetite in healthy males. Am J Physiol Regul Integr Comp Physiol 296, R912-R920.

78. Blom WA, Lluch A, Stafleu A, et al. (2006) Effect of a highprotein breakfast on the postprandial ghrelin response. Am J Clin Nutr 83, 211-220.

79. Mossner J, Grumann M, Zeeh J, et al. (1992) Influence of various nutrients and their mode of application on plasma cholecystokinin (CCK) bioactivity. Clin Invest 70, 125-129.

80. Anika SM, Houpt TR \& Houpt KA (1981) Cholecystokinin and satiety in pigs. Am J Physiol 240, R310-R318.

81. Houpt TR (1983) The sites of action of cholecystokinin in decreasing meal size in pigs. Physiol Behav 31, 693-698.

82. Baldwin BA, Cooper TR \& Parrott RF (1983) Intravenous cholecystokinin octapeptide in pigs reduces operant responding for food, water, sucrose solution or radiant heat. Physiol Behav 30, 399-403.
83. Holzer HH, Turkelson CM, Solomon TE, et al. (1994) Intestinal lipid inhibits gastric emptying via CCK and a vagal capsaicin-sensitive afferent pathway in rats. Am J Physiol 267, G625-G629.

84. Reidelberger RD, Hernandez J, Fritzsch B, et al. (2004) Abdominal vagal mediation of the satiety effects of CCK in rats. Am J Physiol Regul Integr Comp Physiol 286, R1005-R1012.

85. Ebenezer IS, Vellucci SV \& Parrott RF (2001) The differential effects of intravenously administered 8-OH-DPAT on operant food intake in satiated and food-deprived pigs are mediated by central $5-\mathrm{HT}_{1 \mathrm{~A}}$ receptors. Physiol Behav $\mathbf{7 3}$, 223-227.

86. Reidelberger RD \& O'Rourke MF (1989) Potent cholecystokinin antagonist L 364718 stimulates food intake in rats. $\mathrm{Am} \mathrm{J}$ Physiol 257, R1512-R1518.

87. Woltman TA, Hulce M \& Reidelberger RD (1999) Relative blood-brain barrier permeabilities of the cholecystokinin receptor antagonists devazepide and A-65186 in rats. J Pharm Pharmacol 51, 917-920.

88. Ebenezer IS, de la Riva C \& Baldwin BA (1990) Effects of the CCK receptor antagonist MK-329 on food intake in pigs. Physiol Behav 47, 145-148.

89. Gregory PC, McFadyen M \& Rayner DV (1989) Duodenal infusion of fat, cholecystokinin secretion and satiety in the pig. Physiol Behav 45, 1021-1024.

90. Baldwin BA \& Sukhchai S (1996) Intracerebroventricular injection of CCK reduces operant sugar intake in pigs. Physiol Behav 60, 231-233.

91. Farmer C, Roy N, Rushen J, et al. (2001) Feeding motivation in swine: relation with insulin, glucose \& free fatty acids in portal and jugular blood, and involvement of cholecystokinin. Can J Anim Sci 81, 75-82.

92. Baldwin BA, de la Riva C \& Gerskowitch VP (1994) Effect of a novel CCKA receptor antagonist (2-NAP) on the reduction in food intake produced by CCK in pigs. Physiol Behav $\mathbf{5 5}$, 175-179.

93. Wolkowitz OM, Gertz B, Weingartner H, et al. (1990) Hunger in humans induced by MK-329, a specific peripheral-type cholecystokinin receptor antagonist. Biol Psychiatry 28, 169-173.

94. Holst JJ (2007) The physiology of glucagon-like peptide 1. Physiol Rev 87, 1409-1439.

95. Souza da Silva C, Haenen D, Koopmans SJ, et al. (2014) Effects of resistant starch on behaviour, satiety-related hormones and metabolites in growing pigs. Animal 8, 1402-1411.

96. Hooda S, Matte JJ, Vasanthan T, et al. (2010) Dietary oat $\beta$-glucan reduces peak net glucose flux and insulin production and modulates plasma incretin in portal-vein catheterized grower pigs. J Nutr 140, 1564-1569.

97. Knapper JM, Morgan LM, Fletcher JM, et al. (1995) Plasma and intestinal concentrations of GIP and GLP-1 (7-36) amide during suckling and after weaning in pigs. Horm Metab Res 27, 485-490.

98. Lavin JH, Wittert GA, Andrews J, et al. (1998) Interaction of insulin, glucagon-like peptide 1 , gastric inhibitory polypeptide, and appetite in response to intraduodenal carbohydrate. Am J Clin Nutr 68, 591-598.

99. Verdich C, Toubro S, Buemann B, et al. (2001) The role of postprandial releases of insulin and incretin hormones in meal-induced satiety - effect of obesity and weight reduction. Int $J$ Obes Relat Metab Disord 25, 1206-1214

100. Asmar M (2011) New physiological effects of the incretin hormones GLP-1 and GIP. Dan Med Bull 58, B4248. 
101. Ribel U, Larsen MO, Rolin B, et al. (2002) NN2211: a longacting glucagon-like peptide-1 derivative with anti-diabetic effects in glucose-intolerant pigs. Eur J Pharmacol 451, 217-225.

102. Litten-Brown JC, Corson AM \& Clarke L (2010) Porcine models for the metabolic syndrome, digestive and bone disorders: a general overview. Animal 4, 899-920.

103. Knudsen LB (2010) Liraglutide: the therapeutic promise from animal models. Int J Clin Pract Suppl 167, 4-11.

104. Turton MD, O'Shea D, Gunn I, et al. (1996) A role for glucagon-like peptide- 1 in the central regulation of feeding. Nature 379, 69-72.

105. Sheikh SP, Holst JJ, Orskov C, et al. (1989) Release of PYY from pig intestinal mucosa; luminal and neural regulation. Regul Pept 26, 253-266.

106. Degen L, Oesch S, Casanova M, et al. (2005) Effect of peptide YY3-36 on food intake in humans. Gastroenterology 129, $1430-1436$.

107. Ito T, Thidarmyint H, Murata $\mathrm{T}$, et al. (2006) Effects of peripheral administration of PYY3-36 on feed intake and plasma acyl-ghrelin levels in pigs. J Endocrinol 191, 113-119.

108. Govoni N, De Iasio R, Cocco C, et al. (2005) Gastric immunolocalization and plasma profiles of acyl-ghrelin in fasted and fasted-refed prepuberal gilts. J Endocrinol 186, 505-513.

109. Kojima M \& Kangawa K (2005) Ghrelin: structure and function. Physiol Rev 85, 495-522.

110. Zhang H, Yin J, Li D, et al. (2007) Tryptophan enhances ghrelin expression and secretion associated with increased food intake and weight gain in weanling pigs. Domest Anim Endocrinol 33, 47-61.

111. Inoue H, Watanuki M, Myint HT, et al. (2005) Effects of fasting and refeeding on plasma concentrations of leptin, ghrelin, insulin, growth hormone and metabolites in swine. Anim Sci J 76, 367-374.

112. Scrimgeour K, Gresham MJ, Giles LR, et al. (2008) Ghrelin secretion is more closely aligned to energy balance than with feeding behaviour in the grower pig. J Endocrinol 198, $135-145$.

113. Cummings DE, Purnell JQ, Frayo RS, et al. (2001) A preprandial rise in plasma ghrelin levels suggests a role in meal initiation in humans. Diabetes 50, 1714-1719.

114. Salfen BE, Carroll JA, Keisler DH, et al. (2004) Effects of exogenous ghrelin on feed intake, weight gain, behavior, and endocrine responses in weanling pigs. J Anim Sci 82, $1957-1966$.

115. Le Roux CW, Neary NM, Halsey TJ, et al. (2005) Ghrelin does not stimulate food intake in patients with surgical procedures involving vagotomy. J Clin Endocrinol Metab 90, 4521-4524.

116. Sternini C, Anselmi L \& Rozengurt E (2008) Enteroendocrine cells: a site of 'taste' in gastrointestinal chemosensing. Curr Opin Endocrinol Diabetes Obes 15, 73-78.

117. Vickers MH (2014) Early life nutrition, epigenetics and programming of later life disease. Nutrients 6, 2165-2178.

118. Portha B, Fournier A, Kioon MD, et al. (2014) Early environmental factors, alteration of epigenetic marks and metabolic disease susceptibility. Biochimie 97, 1-15.

119. Cani PD \& Delzenne NM (2009) The role of the gut microbiota in energy metabolism and metabolic disease. Curr Pharm Des 15, 1546-1558.

120. Lallès JP (2009) Basis and regulation of gut barrier function and epithelial cell proliferation - applications to the weaned pig. In Dynamics in Animal Nutrition, pp. 31-51 [J Doppenberg and PJ Van der Aar, editors]. Wageningen: Wageningen Academic Publishers.
121. Keita AV \& Soderholm JD (2010) The intestinal barrier and its regulation by neuroimmune factors. Neurogastroenterol Motil 22, 718-733.

122. Mani V, Weber TE, Baumgard LH, et al. (2012) Growth and Development Symposium: Endotoxin, inflammation, and intestinal function in livestock. J Anim Sci 90, 1452-1465.

123. Miele L, Valenza V, La Torre G, et al. (2009) Increased intestinal permeability and tight junction alterations in nonalcoholic fatty liver disease. Hepatology 49, 1877-1887.

124. Leber B, Tripolt NJ, Blattl D, et al. (2012) The influence of probiotic supplementation on gut permeability in patients with metabolic syndrome: an open label, randomized pilot study. Eur J Clin Nutr 66, 1110-1115.

125. Horton F, Wright J, Smith L, et al. (2014) Increased intestinal permeability to oral chromium $\left({ }^{51} \mathrm{Cr}\right)$-EDTA in human type 2 diabetes. Diabet Med 31, 559-563.

126. Lallès JP (2014) Intestinal alkaline phosphatase: novel functions and protective effects. Nutr Rev 72, 82-94.

127. Arnal ME \& Lallès JP (2016) Gut epithelial inducible heat shock proteins: protective properties and modulation by the microbiota and the diet. Nutr Rev 74, 181-197.

128. Pastorelli L, De Salvo C, Mercado JR, et al. (2013) Central role of the gut epithelial barrier in the pathogenesis of chronic intestinal inflammation: lessons learned from animal models and human genetics. Front Immunol 4, 280.

129. Nejdfors P, Ekelund M, Jeppsson B, et al. (2000) Mucosal in vitro permeability in the intestinal tract of the pig, the rat, and man: species- and region-related differences. Scand J Gastroenterol 35, 501-507.

130. Wallon C, Yang PC, Keita AV, et al. (2008) Corticotropinreleasing hormone (CRH) regulates macromolecular permeability via mast cells in normal human colonic biopsies in vitro. Gut 57, 50-58.

131. Smith F, Clark JE, Overman BL, et al. (2010) Early weaning stress impairs development of mucosal barrier function in the porcine intestine. Am J Physiol Gastrointest Liver Physiol 298, G352-G363.

132. Overman EL, Rivier JE \& Moeser AJ (2012) CRF induces intestinal epithelial barrier injury via the release of mast cell proteases and TNF- $\alpha$. PLOS ONE 7, e39935.

133. Vanuytsel T, van Wanrooy S, Vanheel H, et al. (2014) Psychological stress and corticotropin-releasing hormone increase intestinal permeability in humans by a mast celldependent mechanism. Gut 63, 1293-1299.

134. Yang Y, Wandler AM, Postlethwait JH, et al. (2012) Dynamic evolution of the LPS-detoxifying enzyme intestinal alkaline phosphatase in zebrafish and other vertebrates. Front Immunol 3, 314.

135. Lackeyram D, Yang C, Archbold T, et al. (2010) Early weaning reduces small intestinal alkaline phosphatase expression in pigs. $J$ Nutr 140, 461-468.

136. Tuin A, Poelstra K, de Jager-Krikken A, et al. (2009) Role of alkaline phosphatase in colitis in man and rats. Gut 58, 379-387.

137. Arnal ME, Zhang J, Messori S, et al. (2014) Early changes in microbial colonization selectively modulate intestinal enzymes, but not inducible heat shock proteins in young adult Swine. PLOS ONE 9, e98730.

138. Beumer C, Wulferink M, Raaben W, et al. (2003) Calf intestinal alkaline phosphatase, a novel therapeutic drug for lipopolysaccharide (LPS)-mediated diseases, attenuates LPS toxicity in mice and piglets. J Pharmacol Exp Ther 307, 737-744.

139. Lukas M, Drastich P, Konecny M, et al. (2010) Exogenous alkaline phosphatase for the treatment of patients with moderate to severe ulcerative colitis. Inflamm Bowel Dis $\mathbf{1 6}$, $1180-1186$ 
140. Laugerette F, Vors C, Peretti N, et al. (2011) Complex links between dietary lipids, endogenous endotoxins and metabolic inflammation. Biochimie 93, 39-45.

141. Amar J, Burcelin R, Ruidavets JB, et al. (2008) Energy intake is associated with endotoxemia in apparently healthy men. Am J Clin Nutr 87, 1219-1223.

142. Mani V, Hollis JH \& Gabler NK (2013) Dietary oil composition differentially modulates intestinal endotoxin transport and postprandial endotoxemia. Nutr Metab 10, 6 .

143. Domar U, Karpe F, Hamsten A, et al. (1993) Human intestinal alkaline phosphatase - release to the blood is linked to lipid absorption, but removal from the blood is not linked to lipoprotein clearance. Eur J Clin Invest 23, 753-760.

144. Fan MZ, Adeola O \& Asem EK (1999) Characterization of brush border membrane-bound alkaline phosphatase activity in different segments of the porcine small intestine. $J$ Nutr Biochem 10, 299-305.

145. Lindemann G, Grohs M, Stange EF, et al. (2001) Limited heatshock protein 72 induction in Caco-2 cells by l-glutamine. Digestion 64, 81-86.

146. Yi D, Hou Y, Wang L, et al. (2015) l-Glutamine enhances enterocyte growth via activation of the mTOR signaling pathway independently of AMPK. Amino Acids 47, 65-78.

147. Benjamin J, Makharia G, Ahuja V, et al. (2012) Glutamine and whey protein improve intestinal permeability and morphology in patients with Crohn's disease: a randomized controlled trial. Dig Dis Sci 57, 1000-1012.

148. Ewaschuk JB, Murdoch GK, Johnson IR, et al. (2011) Glutamine supplementation improves intestinal barrier function in a weaned piglet model of Escherichia coli infection. BrJ Nutr 106, 870-877.

149. Zhong X, Zhang XH, Li XM, et al. (2011) Intestinal growth and morphology is associated with the increase in heat shock protein 70 expression in weaning piglets through supplementation with glutamine. J Anim Sci 89, 3634-3642.

150. Lodemann U, Einspanier R, Scharfen F, et al. (2013) Effects of zinc on epithelial barrier properties and viability in a human and a porcine intestinal cell culture model. Toxicol In Vitro 27, 834-843.

151. Hales CN \& Barker DJ (1992) Type 2 (non-insulin-dependent) diabetes mellitus: the thrifty phenotype hypothesis. Diabetologia 35, 595-601.

152. Nehring I, Kostka T, von Kries R, et al. (2015) Impacts of in utero and early infant taste experiences on later taste acceptance: a systematic review. J Nutr 145, 1271-1279.

153. Mennella JA (2014) Ontogeny of taste preferences: basic biology and implications for health. Am J Clin Nutr 99, 704S-711S.

154. Hepper PG, Wells DL, Millsopp S, et al. (2012) Prenatal and early sucking influences on dietary preference in newborn, weaning, and young adult cats. Chem Senses 37, 755-766.

155. Lallès JP (2012) Long term effects of pre- and early postnatal nutrition and environment on the gut. J Anim Sci 90, Suppl. 4, 421-429.

156. Lallès JP, Michel C, Theodorou V, et al. (2015) Epigenetic regulation of gastrointestinal epithelial barrier and developmental origins of health and disease. In The Epigenome and Developmental Origins of Health and Disease, pp. 337-360 [C Rosenfeld, editor]. London: Academic Press.

157. Chatelais L, Jamin A, Gras-Le Guen C, et al. (2011) The level of protein in milk formula modifies ileal sensitivity to LPS later in life in a piglet model. PLoS One 6, e19594.

158. Boudry G, Jamin A, Chatelais L, et al. (2013) Dietary protein excess during neonatal life alters colonic microbiota and mucosal response to inflammatory mediators later in life in female pigs. J Nutr 143, 1225-1232.
159. Arnal ME, Zhang J, Erridge C, et al. (2015) Maternal antibiotic-induced early changes in microbial colonization selectively modulate colonic permeability and inducible heat shock proteins, and digesta concentrations of alkaline phosphatase and TLR-stimulants in swine offspring. PLOS One 10, e0118092.

160. Lakshmy R (2013) Metabolic syndrome: role of maternal undernutrition and fetal programming. Rev Endocr Metab Disord 14, 229-240.

161. Salam RA, Das JK \& Bhutta ZA (2014) Impact of intrauterine growth restriction on long-term health. Curr Opin Clin Nutr Metab Care 17, 249-254.

162. Ferenc K, Pietrzak P, Godlewski MM, et al. (2014) Intrauterine growth retarded piglet as a model for humans - studies on the perinatal development of the gut structure and function. Reprod Biol 14, 51-60.

163. Zhong X, Li W, Huang X, et al. (2012) Impairment of cellular immunity is associated with overexpression of heat shock protein 70 in neonatal pigs with intrauterine growth retardation. Cell Stress Chaperon 17, 495-505.

164. Wang X, Lin G, Liu C, et al. (2014) Temporal proteomic analysis reveals defects in small-intestinal development of porcine fetuses with intrauterine growth restriction. $J$ Nutr Biochem 25, 785-795.

165. D'Inca R, Kloareg M, Gras-Le Guen C, et al. (2010) Intrauterine growth restriction modifies the developmental pattern of intestinal structure, transcriptomic profile, and bacterial colonization in neonatal pigs. J Nutr $\mathbf{1 4 0}$, 925-931.

166. Boudry G, Morise A, Seve B, et al. (2011) Effect of milk formula protein content on intestinal barrier function in a porcine model of LBW neonates. Pediatr Res 69, 4-9.

167. Weng M \& Walker WA (2013) The role of gut microbiota in programming the immune phenotype. J Dev Orig Health Dis 4, 203-214.

168. Lallès JP, Bosi P, Smidt H, et al. (2007) Nutritional management of gut health in pigs around weaning. Proc Nutr Soc $\mathbf{6 6}$, 260-268.

169. Lallès JP, Bosi P, Janczyk P, et al. (2009) Impact of bioactive substances on the gastrointestinal tract and performance of weaned piglets: a review. Animal 3, 1625-1643.

170. Lallès JP \& Guillou D (2015) Pig intestine, weaning and dietary interventions. In Intestinal Health, Key to Optimise Production, pp. 139-168 [T Niewold, editor]. Wageningen: Wageningen Academic Publishers.

171. Ley RE, Hamady M, Lozupone C, et al. (2008) Evolution of mammals and their gut microbes. Science 320, 1647-1651.

172. Del Chierico F, Vernocchi P, Bonizzi L, et al. (2012) Early-life gut microbiota under physiological and pathological conditions: the central role of combined meta-omics-based approaches. J Proteomics 75, 4580-4587.

173. Arumugam M, Raes J, Pelletier E, et al. (2011) Enterotypes of the human gut microbiome. Nature 473, 174-180.

174. Hildebrand F, Nguyen TL, Brinkman B, et al. (2013) Inflammation-associated enterotypes, host genotype, cage and inter-individual effects drive gut microbiota variation in common laboratory mice. Genome Biol 14, R4.

175. Mach N, Berri M, Estelle J, et al. (2015) Early life establishment of the swine gut microbiome and impact on host phenotypes. Environ Microbiol Rep 7, 554-569.

176. Lamendella R, VerBerkmoes N \& Jansson JK (2012) 'Omics' of the mammalian gut - new insights into function. Curr Opin Biotechnol 23, 491-500.

177. Donovan SM, Wang M, Li M, et al. (2012) Host-microbe interactions in the neonatal intestine: role of human milk oligosaccharides. Adv Nutr 3, 450S-455S. 
178. Erickson AR, Cantarel BL, Lamendella R, et al. (2012) Integrated metagenomics/metaproteomics reveals human host-microbiota signatures of Crohn's disease. PLoS One 7, e49138.

179. Le Bourgot C, Ferret-Bernard S, Le Normand L, et al. (2014) Maternal short-chain fructooligosaccharide supplementation influences intestinal immune system maturation in piglets. PLoS One 9, e107508.

180. Heinritz SN, Mosenthin R \& Weiss E (2013) Use of pigs as a potential model for research into dietary modulation of the human gut microbiota. Nutr Res Rev 26, 191-209.

181. Zhao W, Wang Y, Liu S, et al. (2015) The dynamic distribution of porcine microbiota across different ages and gastrointestinal tract segments. PLoS One 10, e0117441.

182. Eckburg PB, Bik EM, Bernstein CN, et al. (2005) Diversity of the human intestinal microbial flora. Science $\mathbf{3 0 8}$, $1635-1638$.

183. Ley RE, Backhed F, Turnbaugh $\mathrm{P}$, et al. (2005) Obesity alters gut microbial ecology. Proc Natl Acad Sci U S A 102, 11070-11075.

184. Ley RE, Turnbaugh PJ, Klein S, et al. (2006) Microbial ecology: human gut microbes associated with obesity. Nature 444, 1022-1023.

185. Leser TD, Amenuvor JZ, Jensen TK, et al. (2002) Cultureindependent analysis of gut bacteria: the pig gastrointestinal tract microbiota revisited. Appl Environ Microbiol 68, 673-690.

186. Guo X, Xia X, Tang R, et al. (2008) Development of a real-time PCR method for Firmicutes and Bacteroidetes in faeces and its application to quantify intestinal population of obese and lean pigs. Lett Appl Microbiol 47, 367-373.

187. Knights D, Ward TL, McKinlay CE, et al. (2014) Rethinking "enterotypes". Cell Host Microbe 16, 433-437.

188. Saraoui T, Parayre S, Guernec G, et al. (2013) A unique in vivo experimental approach reveals metabolic adaptation of the probiotic Propionibacterium freudenreichii to the colon environment. BMC Genomics 14, 911.

189. Chowdhury SR, King DE, Willing BP, et al. (2007) Transcriptome profiling of the small intestinal epithelium in germfree versus conventional piglets. BMC Genomics $\mathbf{8}, 215$.

190. Backhed F, Ding H, Wang T, et al. (2004) The gut microbiota as an environmental factor that regulates fat storage. Proc Natl Acad Sci U S A 101, 15718-15723.

191. Hooper LV (2004) Bacterial contributions to mammalian gut development. Trends Microbiol 12, 129-134.

192. El Aidy S, Dinan TG \& Cryan JF (2015) Gut microbiota: the conductor in the orchestra of immune-neuroendocrine communication. Clin Ther 37, 954-967.

193. Bailey M, Haverson K, Inman C, et al. (2005) The development of the mucosal immune system pre- and post-weaning: balancing regulatory and effector function. Proc Nutr Soc 64, 451-457.

194. Le Huërou-Luron I \& Ferret-Bernard S (2015) Development of gut and gut-associated lymphoid tissues in piglets: role of maternal environment. In The Gestating and Lactating Sow, pp. 335-356 [C Farmer, editor]. Wageningen: Wageningen Academic Publishers.

195. Le Bourgot C, Ferret-Bernard S, Apper-Bossard E, et al. (2013) A maternal scFOS supplementation modulates maturation of the immune system of piglets. In Proceedings of the 64th Annual Meeting of the European Federation of Animal Science. Nantes, France. 20-30 August 2013, p. 552. Wageningen: Wageningen Academic Publishers.

196. Adkins B, Leclerc C \& Marshall-Clarke S (2004) Neonatal adaptive immunity comes of age. Nat Rev Immunol 4, $553-564$
197. Wilson CB, Westall J, Johnston L, et al. (1986) Decreased production of interferon- $\gamma$ by human neonatal cells. Intrinsic and regulatory deficiencies. J Clin Invest 77, 860-867.

198. Thompson CL, Wang B \& Holmes AJ (2008) The immediate environment during postnatal development has long-term impact on gut community structure in pigs. ISME $J \mathbf{2}$, 739-748.

199. Dore J \& Corthier G (2010) The human intestinal microbiota. Gastroenterol Clin Biol 34, Suppl. 1, S7-S15.

200. Cox LM \& Blaser MJ (2015) Antibiotics in early life and obesity. Nat Rev Endocrinol 11, 182-190.

201. Mulder IE, Schmidt B, Stokes CR, et al. (2009) Environmentally-acquired bacteria influence microbial diversity and natural innate immune responses at gut surfaces. BMC Biol 7, 79-99.

202. Mulder IE, Schmidt B, Lewis M, et al. (2011) Restricting microbial exposure in early life negates the immune benefits associated with gut colonization in environments of high microbial diversity. PLoS One 6, e28279.

203. Schokker D, Zhang J, Vastenhouw SA, et al. (2015) Longlasting effects of early-life antibiotic treatment and routine animal handling on gut microbiota composition and immune system in pigs. PLoS One 10, e0116523.

204. Pinsk V, Lemberg DA, Grewal K, et al. (2007) Inflammatory bowel disease in the South Asian pediatric population of British Columbia. Am J Gastroenterol 102, 1077-1083.

205. Boyer PE, D'Costa S, Edwards LL, et al. (2015) Early-life dietary spray-dried plasma influences immunological and intestinal injury responses to later-life Salmonella typhimurium challenge. Br J Nutr 113, 783-793.

206. Le Huërou-Luron I, Blat S \& Boudry G (2010) Breast- $v$. formula-feeding: impacts on the digestive tract and immediate and long-term health effects. Nutr Res Rev 23, 23-36.

207. Aufreiter S, Kim JH \& O'Connor DL (2011) Dietary oligosaccharides increase colonic weight and the amount but not concentration of bacterially synthesized folate in the colon of piglets. J Nutr 141, 366-372.

208. Scholtens PA, Alliet P, Raes M, et al. (2008) Fecal secretory immunoglobulin A is increased in healthy infants who receive a formula with short-chain galacto-oligosaccharides and long-chain fructo-oligosaccharides. $J$ Nutr $\mathbf{1 3 8}$, 1141-1147.

209. Morise A, Seve B, Mace K, et al. (2009) Impact of intrauterine growth retardation and early protein intake on growth, adipose tissue, and the insulin-like growth factor system in piglets. Pediatr Res 65, 45-50.

210. Siggers RH, Siggers J, Thymann T, et al. (2011) Nutritional modulation of the gut microbiota and immune system in preterm neonates susceptible to necrotizing enterocolitis. J Nutr Biochem 22, 511-521.

211. Kim HB, Borewicz K, White BA, et al. (2011) Longitudinal investigation of the age-related bacterial diversity in the feces of commercial pigs. Vet Microbiol 153, 124-133.

212. Fallani M, Young D, Scott J, et al. (2010) Intestinal microbiota of 6-week-old infants across Europe: geographic influence beyond delivery mode, breast-feeding, and antibiotics. J Pediatr Gastroenterol Nutr 51, 77-84.

213. Palmer C, Bik EM, DiGiulio DB, et al. (2007) Development of the human infant intestinal microbiota. PLoS Biol 5, e177.

214. Jakobsson HE, Jernberg C, Andersson AF, et al. (2010) Short-term antibiotic treatment has differing long-term impacts on the human throat and gut microbiome. PLOS One 5, e9836.

215. Strasak L, Bartova E, Harnicarova A, et al. (2009) H3K9 acetylation and radial chromatin positioning. J Cell Physiol 220, 91-101. 
216. Mischke M \& Plosch T (2013) More than just a gut instinct the potential interplay between a baby's nutrition, its gut microbiome, and the epigenome. Am J Physiol Regul Integr Comp Physiol 304, R1065-R1069.

217. Pang X, Hua X, Yang Q, et al. (2007) Inter-species transplantation of gut microbiota from human to pigs. ISME J $\mathbf{1}$, $156-162$.

218. Che C, Pang X, Hua X, et al. (2009) Effects of human fecal flora on intestinal morphology and mucosal immunity in human flora-associated piglet. Scand J Immunol 69, 223-233.

219. Shen J, Zhang B, Wei H, et al. (2010) Assessment of the modulating effects of fructo-oligosaccharides on fecal microbiota using human flora-associated piglets. Arch Microbiol 192, 959-968.

220. Wen K, Tin C, Wang H, et al. (2014) Probiotic Lactobacillus rhamnosus GG enhanced Th1 cellular immunity but did not affect antibody responses in a human gut microbiota transplanted neonatal gnotobiotic pig model. PLoS One 9, e94504.

221. Rolls ET (2006) Brain mechanisms underlying flavour and appetite. Philos Trans R Soc Lond B Biol Sci 361, 1123-1136.

222. Stice E, Spoor S, Ng J, et al. (2009) Relation of obesity to consummatory and anticipatory food reward. Physiol Behav 97, 551-560.

223. Carnell S, Gibson C, Benson L, et al. (2012) Neuroimaging and obesity: current knowledge and future directions. Obes Rev 13, 43-56.

224. Boubaker J, Val-Laillet D, Guerin S, et al. (2012) Brain processing of duodenal and portal glucose sensing. $J \mathrm{Neu}$ roendocrinol 24, 1096-1105.

225. Clouard C, Meunier-Salaün M-C, Meurice P, et al. (2014) Combined compared to dissociated oral and intestinal sucrose stimuli induce different brain hedonic processes. Front Psychol 5, 861

226. Gaultier A, Meunier-Salaun MC, Malbert CH, et al. (2011) Flavour exposures after conditioned aversion or preference trigger different brain processes in anaesthetised pigs. Eur J Neurosci 34, 1500-1511.

227. Clouard C, Jouhanneau M, Meunier-Salaun MC, et al. (2012) Exposures to conditioned flavours with different hedonic values induce contrasted behavioural and brain responses in pigs. PLOS ONE 7, e37968.

228. Low YQ, Lacy K \& Keast R (2014) The role of sweet taste in satiation and satiety. Nutrients $\mathbf{6}, 3431-3450$.

229. Ochoa M, Lallès J-P, Malbert C-H, et al. (2015) Dietary sugars: their detection by the gut-brain axis and their peripheral and central effects in health and diseases. Eur J Nutr 54, 1-24.

230. Johansen T, Hansen HS, Richelsen B, et al. (2001) The obese Göttingen minipig as a model of the metabolic syndrome: dietary effects on obesity, insulin sensitivity, and growth hormone profile. Comp Med 51, 150-155.

231. Clarke IJ (2010) Whatever way weight goes, inflammation shows. Endocrinology 151, 846-848.

232. Neeb ZP, Edwards JM, Alloosh M, et al. (2010) Metabolic syndrome and coronary artery disease in Ossabaw compared with Yucatan swine. Comp Med 60, 300-315.

233. Val-Laillet D, Blat S, Louveau I, et al. (2010) A computed tomography scan application to evaluate adiposity in a minipig model of human obesity. Br J Nutr 104, 1719-1728.

234. Val-Laillet D, Guerin S \& Malbert CH (2010) Slower eating rate is independent to gastric emptying in obese minipigs. Physiol Behav 101, 462-468.

235. Le DS, Pannacciulli N, Chen K, et al. (2006) Less activation of the left dorsolateral prefrontal cortex in response to a meal: a feature of obesity. Am J Clin Nutr 84, 725-731.
236. Le DS, Pannacciulli N, Chen K, et al. (2007) Less activation in the left dorsolateral prefrontal cortex in the reanalysis of the response to a meal in obese than in lean women and its association with successful weight loss. Am J Clin Nutr $\mathbf{8 6}$, 573-579.

237. Volkow ND, Wang GJ, Telang F, et al. (2009) Inverse association between BMI and prefrontal metabolic activity in healthy adults. Obesity (Silver Spring) 17, 60-65.

238. Wang GJ, Volkow ND, Logan J, et al. (2001) Brain dopamine and obesity. Lancet 357, 354-357.

239. Val-Laillet D, Layec S, Guerin S, et al. (2011) Changes in brain activity after a diet-induced obesity. Obesity (Silver Spring) 19, 749-756.

240. Val-Laillet D, Meurice P, Lalles JP, et al. (2013) Central functions altered by chronic high-lipids diets enriched with omega 3, omega 6 or saturated fat. Gastroenterology 144, S837-S837.

241. Lassek WD \& Gaulin SJC (2014) Linoleic and docosahexaenoic acids in human milk have opposite relationships with cognitive test performance in a sample of 28 countries. Prostaglandins Leukot Essent Fatty Acids 91, 195-201.

242. Lassek WD \& Gaulin SJ (2011) Sex differences in the relationship of dietary fatty acids to cognitive measures in American children. Front Evol Neurosci 3, 5.

243. Willatts P, Forsyth JS, DiModugno MK, et al. (1998) Effect of long-chain polyunsaturated fatty acids in infant formula on problem solving at 10 months of age. Lancet 352, 688-691.

244. McNamara RK, Able J, Jandacek R, et al. (2010) Docosahexaenoic acid supplementation increases prefrontal cortex activation during sustained attention in healthy boys: a placebo-controlled, dose-ranging, functional magnetic resonance imaging study. Am J Clin Nutr 91, 1060-1067.

245. Farquharson J, Cockburn F, Patrick WA, et al. (1992) Infant cerebral cortex phospholipid fatty-acid composition and diet. Lancet 340, 810-813.

246. Makrides M, Neumann MA, Byard RW, et al. (1994) Fatty acid composition of brain, retina, and erythrocytes in breast- and formula-fed infants. Am J Clin Nutr 60, 189-194.

247. de la Presa Owens S \& Innis SM (1999) Docosahexaenoic and arachidonic acid prevent a decrease in dopaminergic and serotoninergic neurotransmitters in frontal cortex caused by a linoleic and $\alpha$-linolenic acid deficient diet in formula-fed piglets. J Nutr 129, 2088-2093.

248. de la Presa Owens S \& Innis SM (2000) Diverse, regionspecific effects of addition of arachidonic and docosahexanoic acids to formula with low or adequate linoleic and $\alpha$-linolenic acids on piglet brain monoaminergic neurotransmitters. Pediatr Res 48, 125-130.

249. Ng KF \& Innis SM (2003) Behavioral responses are altered in piglets with decreased frontal cortex docosahexaenoic acid. J Nutr 133, 3222-3227.

250. Grosso G, Galvano F, Marventano S, et al. (2014) Omega-3 fatty acids and depression: scientific evidence and biological mechanisms. Oxid Med Cell Longev 2014, 313570.

251. Denis I, Potier B, Heberden C, et al. (2015) Omega-3 polyunsaturated fatty acids and brain aging. Curr Opin Clin Nutr Metab Care 18, 139-146.

252. Hotujac L \& Kuzman MR (2008) Vagus nerve stimulation in the treatment of pharmacoresistant depression. Neuro Endocrinol Lett 29, Suppl, 1, 133-146.

253. Vonck K, De Herdt V \& Boon P (2009) Vagal nerve stimulation - a 15-year survey of an established treatment modality in epilepsy surgery. Adv Tech Stand Neurosurg $\mathbf{3 4}$, 111-146.

254. Val-Laillet D, Biraben A, Randuineau G, et al. (2010) Chronic vagus nerve stimulation decreased weight gain, food 
consumption and sweet craving in adult obese minipigs. Appetite 55, 245-252.

255. Diaz-Guemes I, Sanchez FM, Luis L, et al. (2007) Continuous vagus nerve stimulation effects on the gut-brain axis in swine. Neuromodulation 10, 52-58.

256. Sobocki J, Krolczyk G, Herman RM, et al. (2005) Influence of vagal nerve stimulation on food intake and body weight results of experimental studies. J Physiol Pharmacol 56, Suppl. 6, 27-33.

257. Matyja A, Thor PJ, Sobocki J, et al. (2004) Effects of vagal pacing on food intake and body mass in pigs. Folia Med Cracov 45, 55-62.

258. Biraben A, Guérin S, Bobillier E, et al. (2008) Central activation after chronic vagus nerve stimulation in pigs: contribution of functional imaging. Bull Acad Vet France 161, 441-448

259. Malbert CH, Guérin S, Bobillier E, et al. (2014) Early changes in brain metabolism following vagal stimulation. In 2 nd Nuclear Technologies for Health Symposium. Nantes, France, 12-14 February 2014. Nantes, France: Labex IRON and Nucsan.

260. McClelland J, Bozhilova N, Campbell I, et al. (2013) A systematic review of the effects of neuromodulation on eating and body weight: evidence from human and animal studies. Eur Eat Disord Rev 21, 436-455.

261. Val-Laillet D, Aarts E, Weber B, et al. (2015) Neuroimaging and neuromodulation approaches to study eating behavior and prevent and treat eating disorders and obesity. NeuroImage Clin 8, 1-31.

262. Halpern CH, Wolf JA, Bale TL, et al. (2008) Deep brain stimulation in the treatment of obesity. J Neurosurg $\mathbf{1 0 9}$, 625-634.

263. Sankar T, Tierney TS \& Hamani C (2012) Novel applications of deep brain stimulation. Surg Neurol Int 3, S26-S33.

264. Whiting DM, Tomycz ND, Bailes J, et al. (2013) Lateral hypothalamic area deep brain stimulation for refractory obesity: a pilot study with preliminary data on safety, body weight, and energy metabolism. J Neurosurg 119, 56-63.

265. Howland RH (2014) Update on deep brain stimulation. J Psychosoc Nurs Ment Health Serv 52, 23-26.

266. Sorensen JC, Nielsen MS, Rosendal F, et al. (2011) Development of neuromodulation treatments in a large animal model - do neurosurgeons dream of electric pigs? Prog Brain Res 194, 97-103.

267. Bjarkam CR, Nielsen MS, Glud AN, et al. (2008) Neuromodulation in a minipig MPTP model of Parkinson disease. $\mathrm{BrJ}$ Neurosurg 22, Suppl. 1, S9-S12.

268. Ettrup KS, Tornoe J, Sorensen JC, et al. (2011) A surgical device for minimally invasive implantation of experimental deep brain stimulation leads in large research animals. J Neurosci Methods 200, 41-46.

269. Melega WP, Lacan G, Gorgulho AA, et al. (2012) Hypothalamic deep brain stimulation reduces weight gain in an obesity-animal model. PLOS ONE 7, e30672.

270. Ettrup KS, Sorensen JC, Rodell A, et al. (2012) Hypothalamic deep brain stimulation influences autonomic and limbic circuitry involved in the regulation of aggression and cardiocerebrovascular control in the Göttingen minipig. Stereotact Funct Neurosurg 90, 281-291.

271. Shon YM, Lee KH, Goerss SJ, et al. (2010) High frequency stimulation of the subthalamic nucleus evokes striatal dopamine release in a large animal model of human DBS neurosurgery. Neurosci Lett 475, 136-140.

272. Volkow ND, Wang GJ \& Baler RD (2011) Reward, dopamine and the control of food intake: implications for obesity. Trends Cogn Sci 15, 37-46.
273. Narayanaswami V, Thompson AC, Cassis LA, et al. (2013) Diet-induced obesity: dopamine transporter function, impulsivity and motivation. Int J Obes (Lond) 37, 1095-1103.

274. Knight EJ, Min HK, Hwang SC, et al. (2013) Nucleus accumbens deep brain stimulation results in insula and prefrontal activation: a large animal fMRI study. PLoS One $\mathbf{8}$, e56640.

275. White E, Woolley M, Bienemann A, et al. (2011) A robust MRI-compatible system to facilitate highly accurate stereotactic administration of therapeutic agents to targets within the brain of a large animal model. J Neurosci Methods 195 , 78-87.

276. Min HK, Hwang SC, Marsh MP, et al. (2012) Deep brain stimulation induces BOLD activation in motor and nonmotor networks: an fMRI comparison study of STN and EN/ GPi DBS in large animals. NeuroImage 63, 1408-1420.

277. Shrivastava D, Abosch A, Hanson T, et al. (2010) Effect of the extracranial deep brain stimulation lead on radiofrequency heating at 9.4 Tesla (400.2 MHz). J Magn Reson Imaging 32, 600-607.

278. Shrivastava D, Abosch A, Hughes J, et al. (2012) Heating induced near deep brain stimulation lead electrodes during magnetic resonance imaging with a $3 \mathrm{~T}$ transceive volume head coil. Phys Med Biol 57, 5651-5665.

279. Gorny KR, Presti MF, Goerss SJ, et al. (2013) Measurements of RF heating during 3.0-T MRI of a pig implanted with deep brain stimulator. Magn Reson Imaging 31, 783-788.

280. Alstrup AKO \& Smith DF (2012) PET neuroimaging in pigs. Scand J Lab Anim Sci 39, 25-45.

281. Agnesi F, Tye SJ, Bledsoe JM, et al. (2009) Wireless Instantaneous Neurotransmitter Concentration System-based amperometric detection of dopamine, adenosine, and glutamate for intraoperative neurochemical monitoring. J Neurosurg 111, 701-711.

282. Van Gompel JJ, Chang SY, Goerss SJ, et al. (2010) Development of intraoperative electrochemical detection: wireless instantaneous neurochemical concentration sensor for deep brain stimulation feedback. Neurosurg Focus 29, E6.

283. Bowyer SM, Okada YC, Papuashvili N, et al. (1999) Analysis of MEG signals of spreading cortical depression with propagation constrained to a rectangular cortical strip. I. Lissencephalic rabbit model. Brain Res 843, 71-78.

284. Uga M, Saito T, Sano T, et al. (2014) Direct cortical hemodynamic mapping of somatotopy of pig nostril sensation by functional near-infrared cortical imaging (fNCI). NeuroImage 91, $138-145$.

285. Innis SM (2000) Essential fatty acids in infant nutrition: lessons and limitations from animal studies in relation to studies on infant fatty acid requirements. Am J Clin Nutr $\mathbf{7 1}$, 238S-244S

286. Innis SM (2000) The role of dietary $n-6$ and $n-3$ fatty acids in the developing brain. Dev Neurosci 22, 474-480.

287. Banks WA (2012) Role of the blood-brain barrier in the evolution of feeding and cognition. Ann N Y Acad Sci 1264, 13-19.

288. Milbury PE \& Kalt W (2010) Xenobiotic metabolism and berry flavonoid transport across the blood-brain barrier. J Agric Food Chem 58, 3950-3956.

289. Pollet S, Albouz S, Le Saux F, et al. (1979) Bismuth intoxication: bismuth level in pig brain lipids and in subcellular fractions. Toxicol Eur Res 2, 123-125.

290. Goti D, Balazs Z, Panzenboeck U, et al. (2002) Effects of lipoprotein lipase on uptake and transcytosis of low density lipoprotein (LDL) and LDL-associated $\alpha$-tocopherol in a porcine in vitro blood-brain barrier model. J Biol Chem $\mathbf{2 7 7}$, $28537-28544$. 
291. Patabendige A (2012) The value of in vitro models of the blood-brain barrier and their uses. Altern Lab Anim 40, 335-338.

292. Patabendige A, Skinner RA \& Abbott NJ (2013) Establishment of a simplified in vitro porcine blood-brain barrier model with high transendothelial electrical resistance. Brain Res 1521, 1-15.

293. Patabendige A, Skinner RA, Morgan L, et al. (2013) A detailed method for preparation of a functional and flexible bloodbrain barrier model using porcine brain endothelial cells. Brain Res 1521, 16-30.

294. Kim CS, Virella A, Braunberg RC, et al. (1996) Kinetic analysis of glutamate transport by the miniswine choroid plexus in vitro. Brain Res 709, 59-64.

295. Mulac D, Huwel S, Galla HJ, et al. (2012) Permeability of ergot alkaloids across the blood-brain barrier in vitro and influence on the barrier integrity. Mol Nutr Food Res 56, 475-485.

296. Weidner M, Huwel S, Ebert F, et al. (2013) Influence of T-2 and HT-2 toxin on the blood-brain barrier in vitro: new experimental hints for neurotoxic effects. PLoS One 8, e60484.

297. Campbell SD, Regina KJ \& Kharasch ED (2014) Significance of lipid composition in a blood-brain barrier-mimetic PAMPA assay. I Biomol Screen 19, 437-444.

298. Buckman LB, Thompson MM, Moreno HN, et al. (2013) Regional astrogliosis in the mouse hypothalamus in response to obesity. J Comp Neurol 521, 1322-1333.

299. Banks WA (2012) Drug delivery to the brain in Alzheimer's disease: consideration of the blood-brain barrier. Adv Drug Deliv Rev 64, 629-639.

300. Adeola O \& Ball RO (1992) Hypothalamic neurotransmitter concentrations and meat quality in stressed pigs offered excess dietary tryptophan and tyrosine. J Anim Sci 70, 1888-1894.

301. Henry Y, Seve B, Colleaux Y, et al. (1992) Interactive effects of dietary levels of tryptophan and protein on voluntary feed intake and growth performance in pigs, in relation to plasma free amino acids and hypothalamic serotonin. J Anim Sci 70, 1873-1887.

302. Henry Y, Seve B, Mounier A, et al. (1996) Growth performance and brain neurotransmitters in pigs as affected by tryptophan, protein, and sex. J Anim Sci 74, 2700-2710.

303. Shen YB, Voilque G, Kim JD, et al. (2012) Effects of increasing tryptophan intake on growth and physiological changes in nursery pigs. J Anim Sci 90, 2264-2275.

304. Elmquist JK, Ross LR, Hsu W, et al. (1993) Cholecystokinin like immunoreactivity in the brains of young Meishan and Duroc pigs. I Anim Breed Genet 110, 473-479.

305. Kenk M, Thomas A, Lortie M, et al. (2011) PET measurements of cAMP-mediated phosphodiesterase- 4 with $(R)-\left[{ }^{11} \mathrm{C}\right]$ rolipram. Curr Radiopharm $\mathbf{4}, 44-58$.

306. Prelusky DB (1993) The effect of low-level deoxynivalenol on neurotransmitter levels measured in pig cerebral spinal fluid. J Environ Sci Health B 28, 731-761.

307. Swamy HV, Smith TK, Karrow NA, et al. (2004) Effects of feeding blends of grains naturally contaminated with Fusarium mycotoxins on growth and immunological parameters of broiler chickens. Poult Sci 83, 533-543.

308. Poletto R, Cheng HW, Meisel RL, et al. (2010) Aggressiveness and brain amine concentration in dominant and subordinate finishing pigs fed the $\beta$-adrenoreceptor agonist ractopamine. J Anim Sci 88, 3107-3120.

309. Gbore FA (2010) Brain and hypophyseal acetylcholinesterase activity of pubertal boars fed dietary fumonisin B1. J Anim Physiol Anim Nutr (Berl) 94, e123-e129.
310. Kanitz E, Otten W, Tuchscherer M, et al. (2012) High and low protein: carbohydrate dietary ratios during gestation alter maternal-fetal cortisol regulation in pigs. PLoS One 7, e52748.

311. Gaige S, Bonnet MS, Tardivel C, et al. (2013) c-Fos immunoreactivity in the pig brain following deoxynivalenol intoxication: focus on NUCB2/nesfatin-1 expressing neurons. Neurotoxicology 34, 135-149.

312. Madsen MB, Birck MM, Fredholm M, et al. (2010) Expression studies of the obesity candidate gene FTO in pig. Anim Biotechnol 21, 51-63.

313. Kumar S \& Bate LA (2004) Scanning electron microscopy of the tongue papillae in the pig (Sus scrofa). Microsc Res Tech 63, 253-258.

314. Wellendorph P, Johansen LD \& Bräuner-Osborne H (2009) Molecular pharmacology of promiscuous seven transmembrane receptors sensing organic nutrients. Mol Pharmacol 76, 453-465.

315. Kuhn C, Bufe B, Batram C, et al. (2010) Oligomerization of TAS2R bitter taste receptors. Chem Senses 35, 395-406.

316. Brockhoff A, Behrens M, Roudnitzky N, et al. (2011) Receptor agonism and antagonism of dietary bitter compounds. J Neurosci 31, 14775-14782.

317. Adlerberth I \& Wold AE (2009) Establishment of the gut microbiota in Western infants. Acta Paediatr 98, 229-238.

318. Wang M, Radlowski EC, Monaco MH, et al. (2013) Mode of delivery and early nutrition modulate microbial colonization and fermentation products in neonatal piglets. J Nutr $\mathbf{1 4 3}$, 795-803.

319. Lind NM, Moustgaard A, Jelsing J, et al. (2007) The use of pigs in neuroscience: modeling brain disorders. Neurosci Biobehav Rev 31, 728-751.

320. Pakkenberg B \& Gundersen HJ (1997) Neocortical neuron number in humans: effect of sex and age. J Comp Neurol 384, 312-320.

321. Jelsing J, Nielsen R, Olsen AK, et al. (2006) The postnatal development of neocortical neurons and glial cells in the Göttingen minipig and the domestic pig brain. J Exp Biol 209, 1454-1462.

322. Christensen JR, Larsen KB, Lisanby SH, et al. (2007) Neocortical and hippocampal neuron and glial cell numbers in the rhesus monkey. Anat Rec (Hoboken) 290, 330-340.

323. Vodicka P, Smetana K Jr, Dvorankova B, et al. (2005) The miniature pig as an animal model in biomedical research. Ann N Y Acad Sci 1049, 161-171.

324. Niblock MM, Luce CJ, Belliveau RA, et al. (2005) Comparative anatomical assessment of the piglet as a model for the developing human medullary serotonergic system. Brain Res Rev 50, 169-183.

325. Conrad MS, Dilger RN \& Johnson RW (2012) Brain growth of the domestic pig (Sus scrofa) from 2 to 24 weeks of age: a longitudinal MRI study. Dev Neurosci 34, 291-298.

326. Zimmer L \& Luxen A (2012) PET radiotracers for molecular imaging in the brain: past, present and future. NeuroImage 61, 363-370.

327. Talairach J \& Tournoux P (1988) Co-planar Stereotaxic Atlas of the Human Brain. New York: Thieme.

328. Félix B, Leger ME, Albe-Fessard D, et al. (1999) Stereotaxic atlas of the pig brain. Brain Res Bull 49, 1-137.

329. Lancaster JL, Woldorff MG, Parsons LM, et al. (2000) Automated Talairach atlas labels for functional brain mapping. Hum Brain Mapp 10, 120-131.

330. Saikali S, Meurice P, Sauleau P, et al. (2010) A threedimensional digital segmented and deformable brain atlas of the domestic pig. J Neurosci Methods 192, 102-109. 
331. Newman L \& Keast RJ (2013) The test-retest reliability of fatty acid taste thresholds. Chemosens Percept 6, 70-77.

332. Conigrave AD \& Hampson DR (2006) Broad-spectrum l-amino acid sensing by class 3 G-protein-coupled receptors. Trends Endocrinol Metab 17, 398-407.

333. Zucker CS, Ryba NJP, Feng L, et al. (2002) An amino-acid taste receptor. Nature 416, 191-194.

334. De Jager N, Zhan M, Rzepus M, et al. (2013) Towards defining the taste receptor repertoire in the pig. In Manipulating Pig Production XIV: Proceedings of the 14th Biennial Conference of the Australasian Pig Science Association: Melbourne Australia; 24-27 November 2013, p. 47. Werribee, VIC: Australasian Pig Science Association (Inc.).

335. Rzepus M, De Jager N, Preston M, et al. (2013) Isoenergetic diets differing in arabinoxylans or $\beta$ glucans show similar taste receptor expression profile in pig tongue. In Manipulating Pig Production XIV: Proceedings of the 14th Biennial Conference of the Australasian Pig Science Association: Melbourne Australia; 24-27 November 2013 p. 46. Werribee, VIC: Australasian Pig Science Association (Inc.).

336. Meyer D, Voigt A, Widmayer P, et al. (2012) Expression of Tas1 taste receptors in mammalian spermatozoa: functional role of Tas1r1 in regulating basal $\mathrm{Ca}^{2+}$ and cAMP concentrations in spermatozoa. PLOS ONE 7, e32354.

337. Bezencon C, le Coutre J \& Damak S (2007) Taste-signaling proteins are coexpressed in solitary intestinal epithelial cells. Chem Senses 32, 41-49.

338. Toyono T, Seta Y, Kataoka S, et al. (2007) CCAAT/enhancerbinding protein $\beta$ regulates expression of human T1R3 taste receptor gene in the bile duct carcinoma cell line, HuCCT1. Biochim Biophys Acta 1769, 641-648.

339. Wauson EM, Zaganjor E, Lee AY, et al. (2012) The G proteincoupled taste receptor T1R1/T1R3 regulates mTORC1 and autophagy. Mol Cell 28, 851-862.

340. Raliou M, Boucher Y, Wiencis A, et al. (2009) Tas1R1-Tas1R3 taste receptor variants in human fungiform papillae. Neurosci Lett 451, 217-221.

341. Flegel C, Manteniotis S, Osthold S, et al. (2013) Expression profile of ectopic olfactory receptors determined by deep sequencing. PLOS ONE 8, e 55368.

342. Symonds EL, Peiris M, Page AJ, et al. (2015) Mechanisms of activation of mouse and human enteroendocrine cells by nutrients. Gut 64, 618-626.

343. Taniguchi K (2004) Expression of the sweet receptor protein, T1R3, in the human liver and pancreas. J Vet Med Sci 66, 1311-1314.

344. Rozengurt E \& Sternini C (2007) Taste receptor signaling in the mammalian gut. Curr Opin Pharmacol 7, 557-562.

345. Jang HJ, Kokrashvili Z, Theodorakis MJ, et al. (2007) Gut-expressed gustducin and taste receptors regulate secretion of glucagon-like peptide-1. Proc Natl Acad Sci US A 104, 15069-15074.

346. Nelson G, Hoon MA, Chandrashekar J, et al. (2001) Mammalian sweet taste receptors. Cell 106, 381-390.

347. Blad CC, Tang C \& Offermanns S (2012) G protein-coupled receptors for energy metabolites as new therapeutic targets. Nat Rev Drug Discov 11, 603-619.

348. Moran AW, Al-Rammahi MA, Arora DK, et al. (2010) Expression of $\mathrm{Na}^{+} /$glucose co-transporter 1 (SGLT1) is enhanced by supplementation of the diet of weaning piglets with artificial sweeteners. Br J Nutr 104, 637-646.

349. Young RL, Sutherland K, Pezos N, et al. (2009) Expression of taste molecules in the upper gastrointestinal tract in humans with and without type 2 diabetes. Gut $\mathbf{5 8}$, 337-346.
350. Zhang X, Bedigian AV, Wang W, et al. (2012) G proteincoupled receptors participate in cytokinesis. Cytoskeleton (Hoboken) 69, 810-818.

351. Elliott RA, Kapoor S \& Tincello DG (2011) Expression and distribution of the sweet taste receptor isoforms T1R2 and T1R3 in human and rat bladders. J Urol 186, $2455-2462$.

352. Montmayeur JP \& Matsunami H (2002) Receptors for bitter and sweet taste. Curr Opin Neurobiol 12, 366-371.

353. Tordoff MG, Alarcon LK, Valmeki S, et al. (2012) T1R3: a human calcium taste receptor. Sci Rep 2, 496.

354. Van der Wielen N, Van Avesaat M, De Wit NJ, et al. (2014) Cross-species comparison of genes related to nutrient sensing mechanisms expressed along the intestine. PLOS ONE 9 , e107531.

355. Dotson CD, Zhang L, Xu H, et al. (2008) Bitter taste receptors influence glucose homeostasis. PLoS One 3, e3974.

356. Rozengurt E (2006) Taste receptors in the gastrointestinal tract. I. Bitter taste receptors and $\alpha$-gustducin in the mammalian gut. Am J Physiol Gastrointest Liver Physiol 291, G171-G177.

357. Foster SR, Porrello ER, Purdue B, et al. (2013) Expression, regulation and putative nutrient-sensing function of taste GPCRs in the heart. PLoS One 8, e64579.

358. Max M, Shanker YG, Huang L, et al. (2001) Tas1r3, encoding a new candidate taste receptor, is allelic to the sweet responsiveness locus Sac. Nat Genet 28, 58-63.

359. Behrens M, Foerster S, Staehler F, et al. (2007) Gustatory expression pattern of the human TAS2R bitter receptor gene family reveals a heterogenous population of bitter responsive taste receptor cells. J Neurosci 27, 12630-12640.

360. Kaji I, Karaki S, Fukami Y, et al. (2009) Secretory effects of a luminal bitter tastant and expressions of bitter taste receptors, T2Rs, in the human and rat large intestine. Am J Physiol Gastrointest Liver Physiol 296, G971-G981.

361. Shah AS, Ben-Shahar Y, Moninger TO, et al. (2009) Motile cilia of human airway epithelia are chemosensory. Science 325, 1131-1134.

362. Deshpande DA, Wang WC, McIlmoyle EL, et al. (2010) Bitter taste receptors on airway smooth muscle bronchodilate by localized calcium signaling and reverse obstruction. Nat Med 16, 1299-1304.

363. Robinett KS, Golding A, Lockatell V, et al. (2014) Differential expression and suppressive function of bitter taste receptors in Th1 and Th2 lymphocytes. B101. Asthma Pathogenesis, p. A3683. http://www.atsjournals.org/doi/abs/10.1164/ajrccmconference.2014.189.1_MeetingAbstracts.A3683 (accessed April 2016).

364. Gerspach AC, Steinert RE, Schonenberger L, et al. (2011) The role of the gut sweet taste receptor in regulating GLP-1, PYY, and CCK release in humans. Am J Physiol Endocrinol Metab 301, E317-E325.

365. Li F (2013) Taste perception: from the tongue to the testis. Mol Hum Reprod 19, 349-360.

366. Soares S, Kohl S, Thalmann S, et al. (2013) Different phenolic compounds activate distinct human bitter taste receptors. J Agric Food Chem 61, 1525-1533.

367. Orsmark-Pietras C, James A, Konradsen JR, et al. (2013) Transcriptome analysis reveals upregulation of bitter taste receptors in severe asthmatics. Eur Respir J 42, 65-78.

368. Pydi SP, Sobotkiewicz T, Billakanti R, et al. (2014) Amino acid derivatives as bitter taste receptor (T2R) blockers. J Biol Chem 289, 25054-25066.

369. Garcia-Esparcia P, Schluter A, Carmona M, et al. (2013) Functional genomics reveals dysregulation of cortical olfactory receptors in Parkinson disease: novel putative 
chemoreceptors in the human brain. I Neuropathol Exp Neurol 72, 524-539.

370. Behrens M \& Meyerhof W (2011) Gustatory and extragustatory functions of mammalian taste receptors. Physiol Behav 105, 4-13.

371. Cohen SP, Buckley BK, Kosloff M, et al. (2012) Regulator of G-protein signaling-21 (RGS21) is an inhibitor of bitter gustatory signaling found in lingual and airway epithelia. J Biol Chem 287, 41706-41719.

372. Lee RJ, Xiong G, Kofonow JM, et al. (2012) T2R38 taste receptor polymorphisms underlie susceptibility to upper respiratory infection. J Clin Invest 122, 4145-4159.

373. Thalmann S, Behrens M \& Meyerhof W (2013) Major haplotypes of the human bitter taste receptor TAS2R41 encode functional receptors for chloramphenicol. Biochem Biophys Res Commun 435, 267-273.

374. Hirasawa A, Tsumaya K, Awaji T, et al. (2005) Free fatty acids regulate gut incretin glucagon-like peptide-1 secretion through GPR120. Nat Med 11, 90-94.

375. Ichimura A, Hirasawa A, Poulain-Godefroy O, et al. (2012) Dysfunction of lipid sensor GPR120 leads to obesity in both mouse and human. Nature 483, 350-354.

376. Fontanesi L, Bertolini F, Scotti E, et al. (2015) Next generation semiconductor based-sequencing of a nutrigenetics target gene (GPR120) and association with average growth rate in Italian large white pigs. Anim Biotechnol 26, 92-97.

377. Briscoe CP, Tadayyon M, Andrews JL, et al. (2003) The orphan $G$ protein-coupled receptor GPR40 is activated by medium and long chain fatty acids. J Biol Chem 278, 11303-11311.

378. Itoh Y, Kawamata Y, Harada M, et al. (2003) Free fatty acids regulate insulin secretion from pancreatic $\beta$ cells through GPR40. Nature 422, 173-176.

379. Del Guerra S, Bugliani M, D'Aleo V, et al. (2010) G-proteincoupled receptor 40 (GPR40) expression and its regulation in human pancreatic islets: the role of type 2 diabetes and fatty acids. Nutr Metab Cardiovasc Dis 20, 22-25.

380. Brown AJ, Goldsworthy SM, Barnes AA, et al. (2003) The orphan G protein-coupled receptors GPR41 and GPR43 are activated by propionate and other short chain carboxylic acids. J Biol Chem 278, 11312-11319.

381. Le Poul E, Loison C, Struyf S, et al. (2003) Functional characterization of human receptors for short chain fatty acids and their role in polymorphonuclear cell activation. $J$ Biol Chem 278, 25481-25489.

382. Haenen D, Zhang J, Souza da Silva C, et al. (2013) A diet high in resistant starch modulates microbiota composition, SCFA concentrations, and gene expression in pig intestine. $J$ Nutr 143, 274-283.

383. Regard JB, Kataoka H, Cano DA, et al. (2007) Probing cell type-specific functions of $\mathrm{G}_{\mathrm{i}}$ in vivo identifies GPCR regulators of insulin secretion. J Clin Invest 117, 4034-4043.

384. Karaki S, Tazoe H, Hayashi H, et al. (2008) Expression of the short-chain fatty acid receptor, GPR43, in the human colon. J Mol Histol 39, 135-142.

385. Tazoe H, Otomo Y, Karaki S, et al. (2009) Expression of short-chain fatty acid receptor GPR41 in the human colon. Biomed Res 30, 149-156.

386. Wang J, Wu X, Simonavicius N, et al. (2006) Medium-chain fatty acids as ligands for orphan $G$ protein-coupled receptor GPR84. J Biol Chem 281, 34457-34464.

387. Laugerette F, Passilly-Degrace P, Patris B, et al. (2005) CD36 involvement in orosensory detection of dietary lipids, spontaneous fat preference, and digestive secretions. J Clin Invest 115, 3177-3184.
388. Simons PJ, Kummer JA, Luiken JJ, et al. (2011) Apical CD36 immunolocalization in human and porcine taste buds from circumvallate and foliate papillae. Acta Histochem 113, 839-843.

389. Simons PJ \& Boon L (2011) Lingual CD36 and obesity: a matter of fat taste? Acta Histochem 113, 765-767 (author reply $768-769$.

390. Fairbairn L, Kapetanovic R, Beraldi D, et al. (2013) Comparative analysis of monocyte subsets in the pig. J Immunol 190, 6389-6396.

391. Wellendorph P, Hansen KB, Balsgaard A, et al. (2005) Deorphanization of GPRC6A: a promiscuous 1 - $\alpha$-amino acid receptor with preference for basic amino acids. Mol Pharmacol 67, 589-597.

392. Wellendorph P \& Brauner-Osborne H (2004) Molecular cloning, expression, and sequence analysis of GPRC6A, a novel family C G-protein-coupled receptor. Gene $\mathbf{3 3 5}$, 37-46.

393. San Gabriel A, Uneyama H, Yoshie S, et al. (2005) Cloning and characterization of a novel mGluR1 variant from vallate papillae that functions as a receptor for l-glutamate stimuli. Chem Senses 30, 25-26.

394. Li S \& Huang Y (2014) In vivo imaging of the metabotropic glutamate receptor 1 (mGluR1) with positron emission tomography: recent advance and perspective. Curr Med Chem 21, 113-123.

395. Wangari-Talbot J, Wall BA, Goydos JS, et al. (2012) Functional effects of GRM1 suppression in human melanoma cells. Mol Cancer Res 10, 1440-1450.

396. Lee HJ, Wall BA, Wangari-Talbot J, et al. (2012) Regulation of mGluR1 expression in human melanocytes and melanoma cells. Biochim Biophys Acta 1819, 1123-1131.

397. Hong S-P, Liu KG, Ma G, et al. (2011) Tricyclic thiazolopyrazole derivatives as metabotropic glutamate receptor 4 positive allosteric modulators. J Med Chem 54, 5070-5081.

398. Conigrave AD, Quinn SJ \& Brown EM (2000) 1-Amino acid sensing by the extracellular $\mathrm{Ca}^{2+}$-sensing receptor. Proc Natl Acad Sci U S A 97, 4814-4819.

399. Conigrave AD, Mun HC, Delbridge L, et al. (2004) l-Amino acids regulate parathyroid hormone secretion. $J$ Biol Chem 279, 38151-38159.

400. Garrett JE, Tamir H, Kifor O, et al. (1995) Calcitonin-secreting cells of the thyroid express an extracellular calcium receptor gene. Endocrinology 136, 5202-5211.

401. Garrett JE, Capuano IV, Hammerland LG, et al. (1995) Molecular cloning and functional expression of human parathyroid calcium receptor cDNAs. J Biol Chem 270, 12919-12925.

402. Chattopadhyay N, Ye C, Singh DP, et al. (1997) Expression of extracellular calcium-sensing receptor by human lens epithelial cells. Biochem Biophys Res Commun 233, 801-805.

403. Mihai R, Stevens J, McKinney C, et al. (2006) Expression of the calcium receptor in human breast cancer - a potential new marker predicting the risk of bone metastases. Eur J Surg Oncol 32, 511-515.

404. Ray JM, Squires PE, Curtis SB, et al. (1997) Expression of the calcium-sensing receptor on human antral gastrin cells in culture. J Clin Invest 99, 2328-2333.

405. Racz GZ, Kittel A, Riccardi D, et al. (2002) Extracellular calcium sensing receptor in human pancreatic cells. Gut 51, 705-711.

406. Topala CN, Schoeber JP, Searchfield LE, et al. (2009) Activation of the $\mathrm{Ca}^{2+}$-sensing receptor stimulates the activity of the epithelial $\mathrm{Ca}^{2+}$ channel TRPV5. Cell Calcium 45, 331-339. 
407. Riccardi D \& Brown EM (2010) Physiology and pathophysiology of the calcium-sensing receptor in the kidney. $A m \mathrm{~J}$ Physiol Renal Physiol 298, F485-F499.

408. Tfelt-Hansen J \& Brown EM (2005) The calcium-sensing receptor in normal physiology and pathophysiology: a review. Crit Rev Clin Lab Sci $\mathbf{4 2}, 35-70$.

409. Buchan AM, Squires PE, Ring M, et al. (2001) Mechanism of action of the calcium-sensing receptor in human antral gastrin cells. Gastroenterology 120, 1128-1139.

410. Justinich CJ, Mak N, Pacheco I, et al. (2008) The extracellular calcium-sensing receptor (CaSR) on human esophagus and evidence of expression of the CaSR on the esophageal epithelial cell line (HET-1A). Am J Physiol Gastrointest Liver Physiol 294, G120-G129.

411. Maeda H, Nakano T, Tomokiyo A, et al. (2010) Mineral trioxide aggregate induces bone morphogenetic protein-2 expression and calcification in human periodontal ligament cells. J Endod 36, 647-652.

412. Lundequist A \& Boyce JA (2011) LPA5 is abundantly expressed by human mast cells and important for lysophosphatidic acid induced MIP-1 $\beta$ release. PLoS One 6, e18192.

413. Lund TC, Kobs AJ, Kramer A, et al. (2013) Bone marrow stromal and vascular smooth muscle cells have chemosensory capacity via bitter taste receptor expression. PLoS One $\mathbf{8}$, e 58945.

414. Midtvedt AC \& Midtvedt T (1992) Production of short chain fatty acids by the intestinal microflora during the first 2 years of human life. J Pediatr Gastroenterol Nutr 15, 395-403.

415. Montagne L, Le Floc'h N, Arturo-Schaan M, et al. (2012) Comparative effects of level of dietary fiber and sanitary conditions on the growth and health of weanling pigs. J Anim Sci 90, 2556-2569.

416. Arbuckle LD \& Innis SM (1993) Docosahexaenoic acid is transferred through maternal diet to milk and to tissues of natural milk-fed piglets. J Nutr 123, 1668-1675.

417. Rooke JA, Bland IM \& Edwards SA (1999) Relationships between fatty acid status of sow plasma and that of umbilical cord, plasma and tissues of newborn piglets when sows were fed on diets containing tuna oil or soyabean oil in late pregnancy. Br J Nutr 82, 213-221.

418. de Quelen F, Boudry G \& Mourot J (2010) Linseed oil in the maternal diet increases long chain-PUFA status of the foetus and the newborn during the suckling period in pigs. $B r J$ Nutr 104, 533-543.

419. Sampels S, Pickova J, Hogberg A, et al. (2011) Fatty acid transfer from sow to piglet differs for different polyunsaturated fatty acids (PUFA). Physiol Res 60, 113-124.

420. Wall KM, Diersen-Schade D \& Innis SM (1994) Plasma and tissue lipids of piglets fed formula containing saturated fatty acids from medium-chain triglycerides with or without fish oil. Am J Clin Nutr 59, 1317-1324.

421. Alessandri JM, Goustard B, Guesnet P, et al. (1996) Polyunsaturated fatty acids status in blood, heart, liver, intestine, retina and brain of newborn piglets fed either sow milk or a milk replacer diet. Reprod Nutr Dev 36, 95-109.

422. Goustard-Langelier B, Guesnet P, Durand G, et al. (1999) n-3 and $n-6$ fatty acid enrichment by dietary fish oil and phospholipid sources in brain cortical areas and nonneural tissues of formula-fed piglets. Lipids 34, 5-16.

423. Morris SA, Simmer KN, van Barneveld R, et al. (1999) Developmental sensitivity of the piglet brain to docosahexanoic acid. Pediatr Res 46, 401-405.

424. Novak EM, Dyer RA \& Innis SM (2008) High dietary omega-6 fatty acids contribute to reduced docosahexaenoic acid in the developing brain and inhibit secondary neurite growth. Brain Res 1237, 136-145.

425. Li P, Kim SW, Li X, et al. (2009) Dietary supplementation with cholesterol and docosahexaenoic acid affects concentrations of amino acids in tissues of young pigs. Amino Acids 37, 709-716.

426. Tyburczy C, Brenna ME, DeMari JA, et al. (2011) Evaluation of bioequivalency and toxicological effects of three sources of arachidonic acid (ARA) in domestic piglets. Food Chem Toxicol 49, 2320-2327.

427. Rytych JL, Elmore MR, Burton MD, et al. (2012) Early life iron deficiency impairs spatial cognition in neonatal piglets. J Nutr 142, 2050-2056.

428. Pierzynowski S, Ushakova G, Kovalenko T, et al. (2014) Impact of colostrum and plasma immunoglobulin intake on hippocampus structure during early postnatal development in pigs. Int J Dev Neurosci 35, 64-71.

429. Pettersen J \& Opstvedt J (1988) Trans fatty acids. 2. Fatty acid composition of the brain and other organs in the mature female pig. Lipids 23, 720-726.

430. Harris KB, Cross HR, Pond WG, et al. (1993) Effect of dietary fat and cholesterol level on tissue cholesterol concentrations of growing pigs selected for high or low serum cholesterol. J Anim Sci 71, 807-810.

431. Dullemeijer C, Zock PL, Coronel R, et al. (2008) Differences in fatty acid composition between cerebral brain lobes in juvenile pigs after fish oil feeding. Br J Nutr 100, 794-800.

432. Pond WG, Mersmann HJ, Su D, et al. (2008) Neonatal dietary cholesterol and alleles of cholesterol 7- $\alpha$ hydroxylase affect piglet cerebrum weight, cholesterol concentration, and behavior. J Nutr 138, 282-286.

433. Lin X, Bo J, Oliver SA, et al. (2011) Dietary conjugated linoleic acid alters long chain polyunsaturated fatty acid metabolism in brain and liver of neonatal pigs. $J$ Nutr Biochem 22, 1047-1054.

434. Hanhineva K, Barri T, Kolehmainen M, et al. (2013) Comparative nontargeted profiling of metabolic changes in tissues and biofluids in high-fat diet-fed Ossabaw pig. J Proteome Res 12, 3980-3992.

435. Castellano CA, Plourde M, Briand SI, et al. (2014) Safety of dietary conjugated $\alpha$-linolenic acid (CLNA) in a neonatal pig model. Food Chem Toxicol 64, 119-125.

436. Jericho KW, Strausz KI \& Martin PJ (1973) Observations on diseased pigs with high sulfate intake and normal tissue copper levels. Can J Comp Med 37, 228-238.

437. Klinghardt GW, Fredman P \& Svennerholm L (1981) Chloroquine intoxication induces ganglioside storage in nervous tissue: a chemical and histopathological study of brain, spinal cord, dorsal root ganglia, and retinal in the miniature pig. J Neurochem 37, 897-908.

438. Tulsiani DR, Broquist HP, James LF, et al. (1988) Production of hybrid glycoproteins and accumulation of oligosaccharides in the brain of sheep and pigs administered swainsonine or locoweed. Arch Biochem Biophys 264, 607-617.

439. Rambeck WA, Brehm HW \& Kollmer WE (1991) The effect of increased copper supplements in feed on the development of cadmium residues in swine [article in German]. Z Ernahrungswiss 30, 298-306.

440. Pond WG, Ellis KJ, Mersmann HJ, et al. (1996) Severe protein deficiency and repletion alter body and brain composition and organ weights in infant pigs. J Nutr 126, 290-302.

441. de Boer VC, Dihal AA, van der Woude H, et al. (2005) Tissue distribution of quercetin in rats and pigs. J Nutr $\mathbf{1 3 5}$, $1718-1725$. 